\title{
BIOLOGIA DE Diatraea saccharalis (FABRICIUS, 1794) (LEPIDOPTERA - PYRALIDAE) EM DIFERENTES TEMPERATURAS PARA DETERMINAÇÃO DAS EXIGÊNCIAS TÉRMICAS
}

\author{
ALEXANDRE BRITO PEREIRA DE MÉLO \\ Engenheiro Agrônomo
}

Orientador: Dr. JOSÉ ROBERTO POSTALI PARRA

Dissertação apresentada à Escola Superior de Agricultura "Luiz de Queiroz", da Universidade de São Paulo, para obtenção do título de Mestre em Ciências Biológicas, Área de Concentração: Entomologia.

PIRACICABA

Estado de São Paulo - Brasil

Fevereiro - 1984 
. ii.

Aos meus pais

\section{Saulo e Mirtes}

e aos meus irmãos

Saulo, Eduardo, Rosário e Ângelo,

OFEREÇO .

À Ana Luzia,

minha esposa,

DEDICO . 


\section{AGRADEC IMENTOS}

Ao Dr. José Roberto Postali Parra, Professor Adjunto do Depar tamento de Entomologia, da Escola Superior de Agricultura "Luiz de Queiroz" (ESALQ), da Universidade de São Paulo (USP), pela criteriosa e objetiva orientação na elaboração do presente trabalho;

Aos Professores do Curso de Pós-Graduação em Entomologia da Es cola Superior de Agricultura "Luiz de Queiroz", pelos ensi namentos transmitidos;

$\bar{A}$ Empresa Brasileira de Pesquisa Agropecuária (EMBRAPA), pela concessão de uma bolsa de estudos para realização do Cur so de Pós-Graduação;

$\overline{\mathrm{A}}$ Financiadora de Estudos e Projetos (FINEP), pelo financiamento da pesquisa;

Ao Dr. Carlos Henrique Mattioli, pesquisador da Empresa Brasi leira de Pesquisa: Agropecuária (EMBRRAPA), pelas análises estatísticas;

Aos Colegas Engenheiros Agrônomos Bonifácio Peixoto Magalhães, Luiz Evaldo de Moura Pádua e Renato José Arleu, pela colaboração e amizade; 
Ao Programa Nacional de Melhoramento da Cana-de-Açúcar (PLANALSUCAR), do Instituto do Açúcar e do Álcool (IAA), pelo auxilio prestado no desenvolvimento desta pesquisa;

A Companhia Industrial e Agrícola de Santa Bárbara D'Oeste , de São Paulo, na pessoa do Engenheiro Agrônomo Hélio José Castilho, pelas facilidades oferecidas para o fornecimento dos insetos para realização deste trabalho;

Aos Pesquisadores da Seção de Climatologia Agrícola do Institú to Agronōmico de Campinas (IAC) e professores do Departamento de Física e Meteorologia da ESALQ/USP, pelo fornecimento dos dados climatológicos utilizados no presente trabalho;

Aos Colegas do Curso de Pós-Graduação pela amizade e estímulos recebidos;

Aos Funcionários da Biblioteca Central da Escola Superior de Agricultura "Luiz de Queiroz", pelas colaborações recebidas;

E a todos que, direta ou indiretamente, colaboraram na execução deste trabalho. 


\section{ÍNDICE}

Página

LISTA DE TABELAS........................ viii

LISTA DE FIGURAS....................... xii

LISTA DE APENDICES...................... xiii

RESUMO ............................. $\quad$ xiv

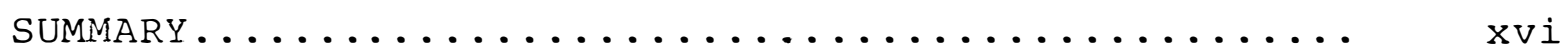

1. INTRODUÇส̃กO.........................

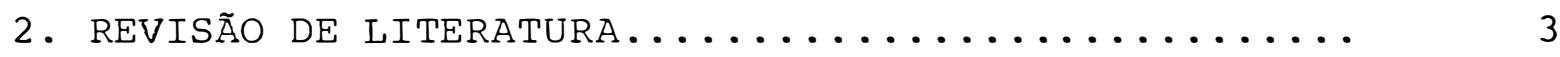

2.1. Técnicas de criação e biologia de Diatraea saccharalis (Fabricius, 1794)............ 3

2.1.1. Em dieta natural............... 3

2.1.2. Em dieta artificial.............. 7

2.2. Influência dos fatores ecológicos sobre $D$.

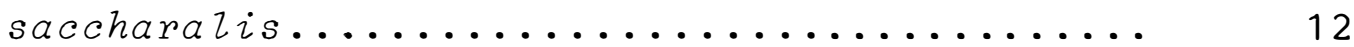

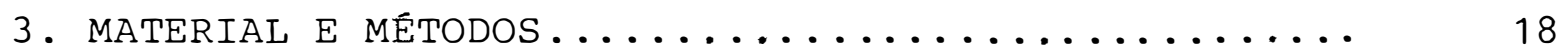

3.1. Colônia inicial de insetos.............. 18

3.2. Biologia em diferentes temperaturas......... 19

3.2.1. Técnica de criação de D. saccharalis.. 20

3.2.1.1. Fase de lagarta........... 20

3.2.1.2. Fase de pupa............. 21

3.2.1.3. Fase adulta............. 22

3.2.1.4. Fase de ovo............. 23 


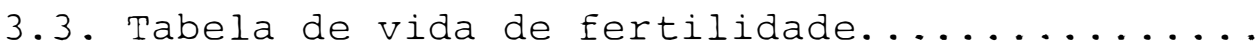

3.4. Análise estatística dos dados biológicos obti dos.

3.5. Determinação da constante térmica..........

3.6. Determinação do nümero de gerações de D. saccharalis, com base nas suas tiigēncias térmicas, em quatro localidades canavieiras do Es-

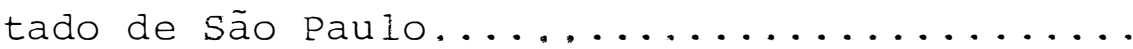

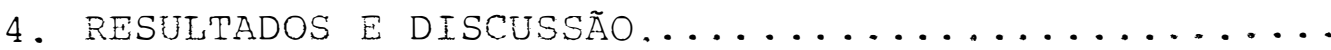

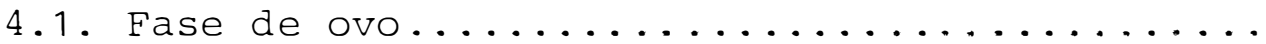

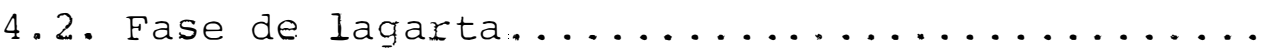

4.2.1. Duração e viabilidade.............

4.2.2. Número, duração e viabilidade dos íns-

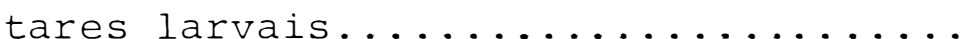

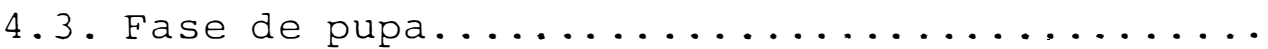

4.3.1. Duração, peso e viabilidade.........

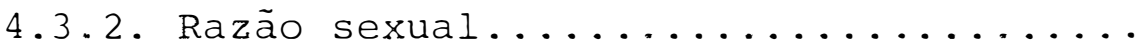

4.4. Fase adulta....................... 46

4.4.1. Longevidade e período de pré-oviposição ...

4.4.2. Período de oviposição e capacidade de

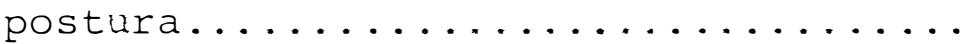

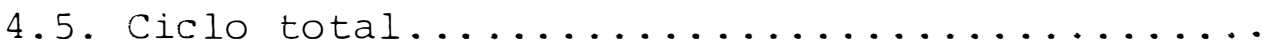

4.6. Tabela de vida de fertilidade.............

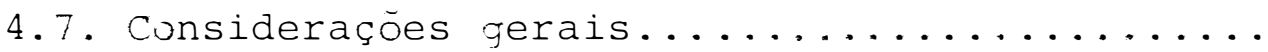


4.8. Determinação das exigências térmicas.........

4.9. Estimativa de número de gerações anuais de $D$.

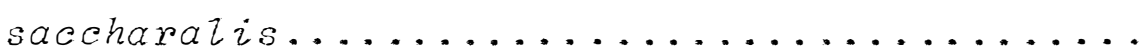

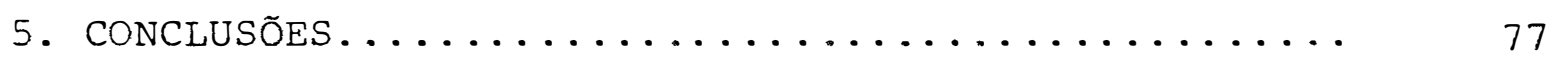

6. LIteratura CITAdA..................... 80

7. APENDICE.................... 


\section{LISTA DE TABELAS}

Tabela

Pāgina

1 Período de incubação e viabilidade dos ovos na coloonia inicial de $D$. saccharalis, em cin co temperaturas. UR: $70 \pm 10 \%$ e fotofase: 14

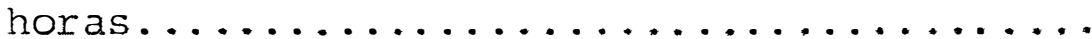

2 Duração média, viabilidade da fase : larval de D. saccharalis, criada em dieta artificial, em cinco temperaturas, com a respecti va contaminação por tratamento. UR: $70 \pm 10 \%$ e fotofase: 14 horas.................

3 Largura média da cāpsula cefálica, razão de crescimento, duração e viabilidade de cada instar de lagartas de $D$. saccharalis, cria das em dieta artificial à $20^{\circ} \mathrm{C}$. UR: $70 \pm 10 \%$,

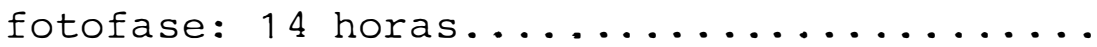

4 Largura média da cápsula cefálica, razão de crescimento, duração e viabilidade de cada instar de lagartas de $D$. saccharalis, cria das em dieta artificial à $22^{\circ} \mathrm{C}$. UR: $70 \pm 10 \%$, fotofase: 14 horas.

5 Largura média da cápsula cefálica, razão de crescimento, duração e viabilidade de cada instar de lagartas de D. saccharalis, cria das em dieta artificial à $25^{\circ} \mathrm{C}$. UR: $70 \pm 10 \%$,

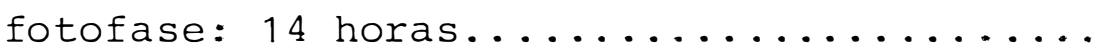


6 Largura média da cápsula cefálica, razão de crescimento, duração e viabilidade de cada instar de lagartasde $D$. saccharalis, cria

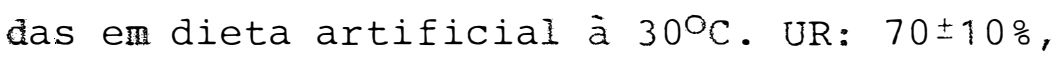

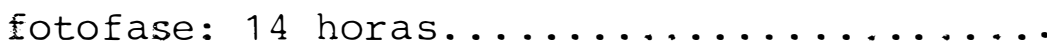

7 Largura média da cápsula cefálica, razão de crescimento, duração e viabilidade de cada instar de lagartas de D. saccharalis, cria das em dieta artificial à $32^{\circ} \mathrm{C}$. UR: $70 \pm 10 \%$,

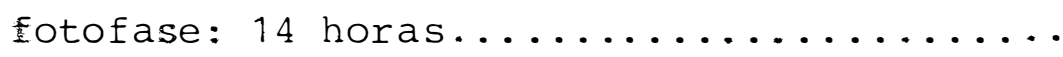

8 Duração e peso de pupas de D. saccharalis, criadas em dieta artificial, com as respecti vas viabilidades, em cinco temperaturas. UR: $70 \pm 10 \%$, fotofase: 14 horas.............

9 Razão sexual e relação sexual de $D$. saccharalis, criada em dieta artificial em cinco temperaturas. UR: $70 \pm 10 \%$, fotofase: 14 ho-

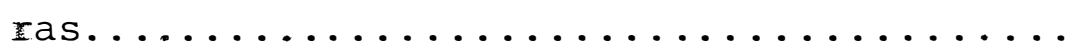

10 Eongevidade de adultos, periodo de pré-oviposição e de pós-oviposição, número de posturas por fêmea, total de ovos e porcenta gem de fêmeas férteis de $D$. saccharalis, mantida em dieta artificial, em cinco tempera turas. UR: $70 \pm 10 \%$ fotofase: 14 horas.....

11 Porcentagem de deformação de adultos de $D$. saccharalis, provenientes de lagartas criadas em dieta artificial em cinco temperaturas. UR: $70 \pm 10 \%$, fotofase: 14 horas....... 
Tabela

12 Duração média (dias) das fases de lagarta, pu pa, adulta e período de incubação dos ovos de D. saccharalis, criada em dieta artificial em diferentes temperaturas. UR: 70 $10 \%$,

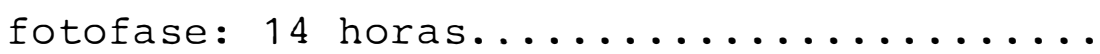

13 Viabilidade total do ciclo de D. sacchara Iis, criada em dieta artificial, em diferen tes temperaturas. UR: $70 \pm 10 \%$, fotofase: 14

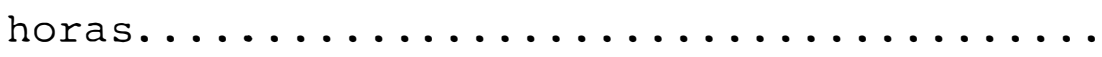

14 Tabela de vida de fertilidade para D. saccharalis, mantida em dieta artificial, à temperatura de $20^{\circ} \mathrm{C}$. UR: $70 \pm 10 \%$, fotofase :

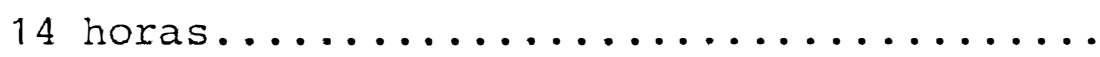

15 Tabela de vida de fertilidade para D. saccharalis, mantida em dieta artificial, à temperatura de $22{ }^{\circ} \mathrm{C}$. UR: $70 \pm 10 \%$, fotofase:

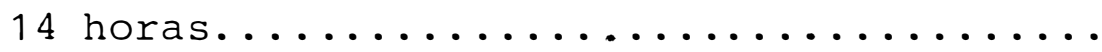

16 Tabela de vida de fertilidade para D. saccharalis, mantida em dieta artificial, à temperatura de $25^{\circ} \mathrm{C}$. UR: $70 \pm 10 \%$, fotofase:

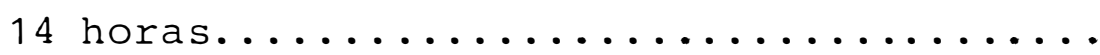

17 Tabela de vida de fertilidade para D. saccharalis, mantida em dieta artificial, à temperatura de $30^{\circ} \mathrm{C}$. UR: $70 \pm 10 \%$, fotofase:

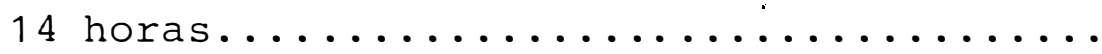


18 Equaçōes logísticas representativas da \% de obtenção de pupas x dias de desenvolvimen to, para D. saccharalis submetida a diferen tes temperaturas, com os resoectivos $T_{50}$.

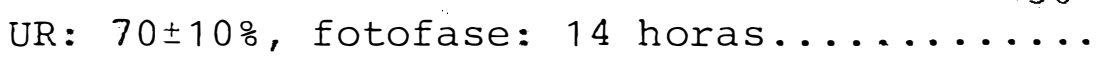

19 Equações logísticas representativas da \% de obtenção de adultos $x$ dias de desenvölvimen to, para D. saccharalis submetida a diferen tes temperaturas, com os respectivos $\mathrm{T}_{50}$. $\mathrm{UR}: 70 \pm 10 \%$, fotofase: 14 horas..........

20 Temperaturas bases (Tb) e constantes térmicas $(K)$ das diferentes fases do ciclo bioló gico de $D$. saccharalis criada em dieta arti

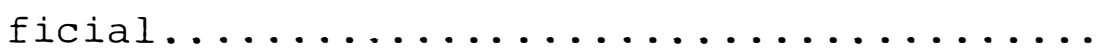




\section{LISTA DE FIGURAS}

Figura

Pāgina

1 Localidades do Estado de são Paulo, selecio nadas para determinação do nūmero de gerações anuais de D. saccharalis, com base em

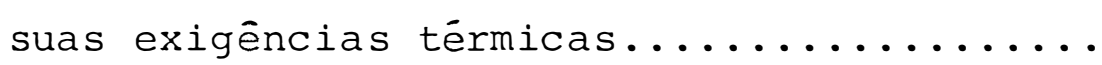

2 Porcentagem de fêmeas de $D$. saccharalis que realizaram postura/dia à $20,22,25$ e $300 \mathrm{C}$.

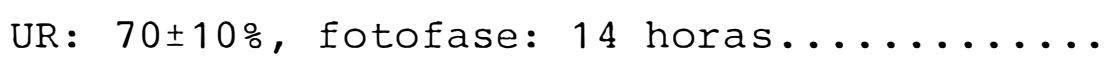

3 Posturas e viabilidades diárias de $D$. saccharalis mantida em dieta artificial à 20 , 22,25 e $300^{\circ}$. UR: $70 \pm 10 \%$, fotofase: 14 ho-

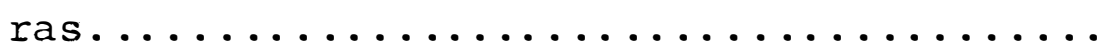

4 Duração média (dias) das fases de ovo, lagarta, pupa e adulto e ciclo total de $D$. saccharalis, criada em dieta artificial em

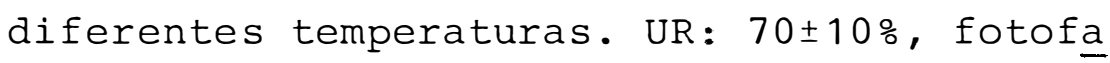

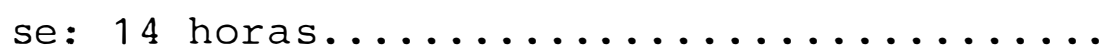

5 Probabilidade de obtenção de pupas de $D$. saccharalis em diferentes temperaturas. UR:

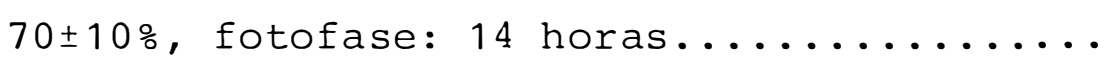

6 Probabilidade de obtenção de adultos de $D$. saccharalis em diferentes temperaturas. UR:

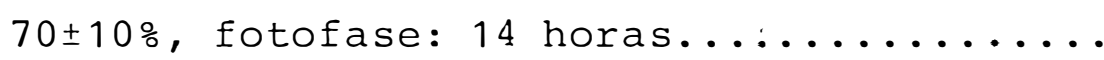

7 Número provável de gerações de D. saccharaZis, com base em sua constante térmica, em Jaú, Pindorama, Ribeirão Preto e Piracicaba (SP) .. 


\section{LISTA DE APÊNDICES}

Apēndice

Pàgina

1 Temperatura média mensal do ar $\left({ }^{\circ} \mathrm{C}\right)$, de Piracicaba, SP, do periodo de 1917 a 1970

2 Temperatura média diária do ar ( $\left.{ }^{\circ} \mathrm{C}\right)$, de Pindorama, SP, do período de 1970 a 1982

3 Temperatura média diāria do ar $\left({ }^{\circ} \mathrm{C}\right)$, de Ribeirão Preto, SP, do período de 1970 a 1982 .

4 Temperatura média diäria do ar $\left({ }^{\circ} \mathrm{C}\right)$, de Jaú, SP, do período de 1970 a 1982..... 


\section{BIOLOGIA DE Diatraea saccharalis (FABRICIUS, 1794) \\ (LePidOPTERA - PyRALIDAE) EM DIFERENTES \\ TEMPERATURAS PARA DETERMINAÇ̃̃O DAS EXIGÊNCIAS TÉRMICAS}

AUTOR: ALEXANDRE BRITO PEREIRA DE MÉLO

ORIENTADOR: DR, JOSÉ ROBERTO POSTALI PARRA

\section{RESUMO}

A biologia de Diatraea saccharalis (Fabricius, 1794) foi estudada em dieta artificial, em cinco temperaturas constantes $\left(20,22,25,30\right.$ e $\left.32^{\circ} \mathrm{C}\right)$, visando fornecer subsidios para a criação massal em condições de laboratório, bem como determinar as exigências térmicas do inseto.

As durações do período de incubação e da fase larval foram decrescentes com a elevação térmica sendo que houve um encurtamento da fase pupal, para ambos os sexos, com 0 aumento de temperatura na faixa de 20 a 300C. A temperatura afetou o número de instares; as lagartas mantidas à 20 e $22^{\circ} \mathrm{C}$, apresentaram sempre seis instares e aquelas criadas à 25, 30 e $32^{\circ} \mathrm{C}, 5$ ou 6 instares. O peso de pupas, de ambos os sexos, foi menor à $32{ }^{\circ} \mathrm{C}$, sendo que em todas as temperaturas as pupas que deram origem a fêmeas foram mais pesadas do que aquelas que originaram machos. A longevidade de adultos foi decrescente com 
o aumento da temperatura na faixa de 20 a $30^{\circ} \mathrm{C}$, sendo que em todas as condições experimentais as fêmeas viveram mais do que os machos. A temperatura não afetou o periodo de pré-oviposição, sendo que o número de posturas diminuiu com a elevação térmica. A temperatura de $200 \mathrm{C}$ foi a mais adequada para oviposição sendo que a maior porcentagem de postura ocorreu entre o primeiro e quarto dias. O ciclo total do inseto decresceu com o incremento térmico, sendo a maior viabilidade obtida à $300^{\circ} \mathrm{C}$. A temperatura de $30^{\circ} \mathrm{C}$ foi a mais adequada para manutenção de ovos, lagartas e pupas de D. saccharalis, sendo a de $32{ }^{\circ} \mathrm{C}$ preju dicial ao normal desenvolvimento do inseto.

A taxa líquida de reprodução $\left(R_{0}\right)$ e a razão $E$ I nita de aumento $(\lambda)$ foram maiores à 20 e $30^{\circ} \mathrm{C}$, respectivamente. As temperaturas bases foram de 11,$2 ; 7,3 ; 10,6$ e $7,1^{\circ} \mathrm{C}$ para as fases de ovo, lagarta, pupa e adulto, respecti vamente, sendo as constantes térmicas das quatro fases lovo, lagarta, pupa e adulto) 67,$47 ; 516,96 ; 126,08$ e 172,02 GD. Baseando-se nas exigências térmicas das diferentes fases evoluti vas do inseto, estimou-se que a praga pode apresentar 5 gerações anuais completas nas localidades de Piracicaba, Ribeirão Preto, Jaú e Pindorama, no Estado de são Paulo. 
.$x v i$.

\begin{abstract}
BIOLOGY OF Diatraea saccharalis (FABRICIUS, 1794)
(LEPIDOPTERA-PyRALIDAE) UNDER DIFFERENT TEMPERATURES FOR THE DETERMINATION OF ITS THERMAL REQUIREMENTS
\end{abstract}

AUTHOR: ALEXANDRE BRITO PEREIRA DE MÉLO

ADVISER: DR, JOSÉ ROBERTO POSTALI PARRA

\title{
SUMMARY
}

The biology of Diatraea saccharalis (Fabricius, 1794) was studied in the laboratory on an artificial diet and under five constant temperatures $\left(20,22,25,30\right.$ and $\left.32^{\circ} \mathrm{C}\right)$. The objective of the study was to optimize the technique for mass rearing of $D$. saccharalis in the laboratory as well as to determine this insect's thermal requirements.

The duration of the incubation period and the larval phase decreased with increasing temperatures, and the pupal phase was shortened, for both sexes, with increasing tem peratures in the range from $20^{\circ}$ to $30^{\circ} \mathrm{C}$. The number of instars was affected by temperature: larvae maintained at 200 and $220 \mathrm{C}$ always presented six instars, while those reared under $25^{\circ}$, $30^{\circ}$, and $32^{\circ} \mathrm{C}$ presented 5 or 6 instars. Pupal weight was lower at $32^{\circ} \mathrm{C}$ for both sexes. Pupal weight of females was higher than 
that of males under all temperatures. Longevity of adults decreased with increasing temperatures in the range from $20^{\circ}$ to 300C. Female adults lived longer than males under all experimental conditions. Temperature did not affect the period of. pre-oviposition. The number of egg-layings decreased with increasing temperatures. The most favorable temperature for egg-laying was $20^{\circ} \mathrm{C}$, and the highest number of egg - layings occurred between the first and the fourth days. The insect's total life cycle decreased with increasing temperatures. The highest viability was obtained at 300C. The most favorable tem perature for maintaining D. saccharalis eggs, Larvae and pupae was $30{ }^{\circ} \mathrm{C}$, while $32^{\circ} \mathrm{C}$ proved to be harmful for the insect's normal development.

The net reproduction ratio $\left(\mathrm{R}_{0}\right)$ and the finite rate of increase $(\lambda)$ were highest at 200 and $300 \mathrm{C}$, respectively. Threshold temperatures for egg, larval, pupal and adult phases were $11.2,7.3,10.6$, and $7.10^{\circ} \mathrm{C}$ respectively, while the thermal requirements for the four phases legg, larva:, pupa and adult) were $67.47,516.96,126.08$, and 172.02 degree days. Based on the thermal requirements of the insect's different biological phases, it was estimated that the pest can complete five generations per year in the localities of Piracicaba, Ribeirão Preto, Jaú and Pindorama, in the state of São Pau 1o, Brazil. 


\section{INTRODUÇÃO}

A cana-de-açúcar é uma cultura de grande importância econômica para alguns países das Américas, especialmente o Brasil, primeiro produtor mundial de açúcar e álcool de cana, com uma produção estimada de 9 milhões de toneladas de a çúcar e cerca de 5,2 bilhões de litros de álcool, para a safra $82 / 83$ (IEA, 1982).

No Estado de São Paulo esta cultura sofre o ata que de inúmeros insetos pragas, os quais se constituem muitas vezes em fatores limitantes à produção sucro-alcooleira. Dentre estes, destaca-se a broca-da-cana, Diatraea saccharalis (Fabricius, 1794), cujas infestações nos canaviais paulistas ocasionam perdas estimadas em cerca de $20 \%$ da produção de açúcar (GALLO, 1980). Como a produção de açúcar deste Estado representa 48,6\% da produção brasileira (IEA, 1982), estas perdas provoca das pela broca são significativas na economia do país. 
A importância dessa praga para a cultura canavieira se prende aos prejuizos diretos e indiretos que ela cau sa à planta. As lagartas causam prejuízos diretos, pela abertu ra de galerias, o que ocasiona perda de peso da cana, morte das gemas, acarretando falhas na germinação e ainda tombamento da cana pelo vento. Os prejuízos indiretos são os mais importantes, pois através dos orifícios e galerias, penetram fungos que causam a inversão da sacarose, diminucindo assim a pureza do caldo e dando menor rendimento em açúcar e álcool fGALIo et a $i$ i, 1978).

Desta forma, torna-se necessário o controle do inseto, o qual vem sendo realizado jā há alguns anos através da criação e liberação de vārios parasitóides de lagartas. Embora o programa de controle biológico da broca-da-cana tenha atingido um bom nível, através de pesquisas realizadas por entidades oficiais e privadas, a sua evolução depende de um melhor conhecimento de aspectos básicos dos insetos nele envolvi dos.

Assim, o presente trabalho teve como objetivo estudar a biologia de D. saccharalis em diferentes temperaturas, visando fornecer subsídios para a criação massal em condi ções de laboratório, bem como avaliar a sua adaptação em diferentes regiões do Estado de São Paulo, tomando-se por base as exigências térmicas deste inseto. 


\section{REVISÃO DE LITERATURA}

\subsection{TÉCNICAS DE CRIACÃO E BIOLOGIA DE Diatraea saccharazis (FABRICIUS, 1794)}

\section{$2,1,1$. EM DIETA NATURAL}

MEADOWS (1938), em biologia desenvolvida em con dições de campo, na Louisiana (EUA), verificou que no verão o período de incubação foi de 4 a 6 dias, enquanto na primavera e outono, a duração desta fase variou de 8 a 12 dias. O período larval foi bastante variável e também dependente da tempera tura; no inverno se estendeu de outubro a março, enquanto que nas demais estações a duração média desta fase foi de 21,2 dias. A fase pupal variou durante 0 ano de 5 a 22 dias, com uma média de duração de 7,3 dias. Segundo o autor, a oviposição e a 
longevidade de adultos foram afetadas pelas condições climáticas. Assim, a média nos meses frios foi de 454 ovos por fêmea e a longevidade dos adultos de 5,8 dias, enquanto nos meses quentes e secos a capacidade de postura foi de 63 ovos por fêmea, com os adultos vivendo de 2 a 4 dias.

BERGAMIN (1943) descreveu dois métodos para cria ção de $D$. saccharalis em colmos de cana-de-açúcar: um método consistiu na utilização de placas de madeira com um orifício circular onde era colocado um pedaço de colmo, do qual se alimentavam as lagartas; o autor observou que a troca periódica do alimento retardou o desenvolvimento larval, não permitindo a determinação da duração real dos instares. Para o outro méto do, foram utilizadas pequenas campânulas de vidro onde eram co locadas lagartas recém-eclodidas sobre pedaços de colmos de 20 a $30 \mathrm{~cm}$ de comprimento, os quais eram trocados a intervalos de 7 a 15 dias. Segundo o autor os dois métodos se complementaram: o primeiro deu condições para observações do comportamento la val e o segundo permitiu estimar a duração desta fase.

Estudando o ciclo biológico da broca-da-cana em condições de laboratório por quatro gerações, TAYLOR (1944) cons tatou um ciclo total médio de 85,7 dias.

BERGAMIN (1948) ao desenvolver a biologia de $D$. saccharalis em colmos de cana observou que o periodo de incuba ção variou de 4 a 9 dias, o período larval de 23 a 64 dias, o periodo de pré-pupa de 2 a 4 dias e o período de pupa de 6 a 14 dias, com as fêmeas apresentando uma capacidade de postura 
de 200 a 300 ovos.

RATKOVICH (1953), ao manter a broca-da-cana-de-açúcar por quatro gerações, em condições não controladas, verificou que o cicio total das três primeiras geraçöes foi de 40 a 50 dias, havendo um alongamento na quarta geração para mais de 200 dias.

WALKER et alii (1966) observaram que lagartas de D. saccharalis, alimentadas com colmos de milho em laboratório, apresentaram um período larval de 50 dias com 5 instares e peso de pupas de 52 e $122 \mathrm{mg}$, respectivamente, para machos e fêmeas. Com relação à fase adulta, constataram que os machos viveram 4 dias e as fêmeas 5 dias, período no qual cada fêmea colocou uma média de 550 ovos. VAN DINTHER e GOOSSENS (1970), ㄸ tilizando o mesmo meio natural, observaram que a fase larval tinha uma duração de 28 dias com uma viabilidade de $70 \%$ e que as pupas pesavam $46 \mathrm{mg}$ e $103 \mathrm{mg}$, respectivamente, se machos ou fêe meas. Em colmos de arroz, estes autores verificaram uma redução na viabilidade para 30\%, com uma duração da fase larval de 30 dias; houve um aumento no peso das pupas que deram origem a machos e diminuição naquelas que originaram fêmeas.

- 7 As exigências térmicas de D. saccharalis, criada: em colmos de milho, foram determinados por JASIC (1967b). Este autor verificou que os limiares de desenvolvimento para ovo, lagarta, pupa e ciclo total foram 12,8; 12,1; 12,6 e 12,50 , respectivamente.

A possibilidade da produção massal de D. saccha 
ralis sobre arroz em casca, a baixo custo e com bastante facilidade, foi demonstrada por MACEDO et alii (1976). Entretanto, os autores ressaltaram a necessidade de se investigar frascos mais adequados, quantidades ideais de arroz, número de lagartas por frasco e o teor de umidade mais conveniente para criação do inseto. VILLACORTA e MAGRO (1975) descreveram uma metodologia de criação de D. saccharalis em laboratório, usando es pigas de milho verde como alimento natural.

GUEVARA (1976), estudando a biologia da broca-da-cana em condições naturais, constatou que o período de incubação foi de 9 dias, o de lagartas 68,9 dias e, o de pupa 10,9 dias, sendo o ciclo total (postura até emergência dos adultos) de 88,8 dias. ARAÚJO et alii (1982) também estudaram o ciclo biológico da praga em condições de campo, obtendo um período de incubação menor ( 8 dias), sendo que para as fases de lagarta e pupa, o período de desenvolvimento foi superior em 1,55 dias e 1 dia, respectivamente. O ciclo total encontrado por estes autores foi de 109,16 dias.

MANPRIM e BORTOLI (1983) estudaram as diferentes fases do ciclo biológico de D. saccharalis em plantas de milho, encontrando que o período de incubação e as fases de la garta e pupa duraram respectivamente 7,$1 ; 43,9$ e 6,4 dias, dan do um ciclo total de 60,6 dias. 


\subsubsection{EM DIETA ARTIFICIAL}

PAN e LONG (1961) realizaram criação massal de D. saccharalis em dieta artificial e em "ponta de cana". Ao me direm o consumo de alimento pelo inseto, os autores não verifi caram diferença significativa entre os dois meios de criação, ob servando que as fêmeas pareciam ser mais sensiveis às deficiências nutricionais do que os machos, em amios os substratos.

WONGSIRI e RANDOLPH (1962) compararam a biologia da broca-da-cana-de-açúcar em dieta artificial à base de germe de trigo e colmos de sorgo, em temperatura de $25^{\circ} \mathrm{C}$. Observaram que o período larval constou de 5 instares em ambos os substratos, sendo que a duração foi menor em meio natural. A du ração da fase pupal foi maior em dieta artificial sendo que o ciclo total foi de 42,8 e 40 dias, respectivamente.

Uma criação massal de $D$. saccharalis foi conduzida por SANTA CRUZ et alii (1964), visando a obtenção de inse tos para estudos da resistēncia de variedades de milho. A fim de desenvolver uma dieta mais adequada para sriação do inseto, os autores compararam quatro dietas e observaram que por trés gerações sucessivas as ãietas à base de soja e milho opaco, fo ram superiores àquelas preparadas com feijão cozido ou cru, com relação à viabilidade pupal, peso médio de pupas, longevidade de adultos e número de ovos por fêmea.

MISKIMEN (1965) estudando o efeito da temperatu彑 ra e umidade relativa do ar no desenvolvimento da broca, veri 
ficou que a melhor temperatura para criação do inseto foi de $26^{\circ} \mathrm{C}$, pois nesta temperatura foram registradas as maiores viabilidades nas diferentes fases e menores porcentagens de anormalidades de adultos. Segundo o autor, o primeiro e segundo instares exigem umidade abaixo de $85 \%$, pois altas umidades podem provocar a condensação das paredes do tubo de criação e provocar a morte destas lagartas; a partir do 39 instar a umidade pode chegar a 90\% sem afetar o normal desenvolvimento do inseto.

Pesquisando uma técnica de criação para $D$. saccharalis utilizando dieta à base de milho, WALKER et alii obtiveram uma viabilidade total (ovo a adulto) de 90\%.

BOWLING (1967) relatou que em dieta à base de feijão, em temperatura de $26,6 \pm 1,6^{\circ} \mathrm{C}$ e fotofase de 14 horas, o período de incubação era de 6,5 dias sendo os períodos larval e pupal de 6,5 a 7,9 dias, respectivamente.

Estudos da biologia de D. saccharalis foram condu zidos por WALKER (1968), visando a aplicação da técnica do inseto estéril. A fim de verificar o melhor estágio para esterilizar o inseto (com raios-y ${ }^{6} \mathrm{Co}$ ), observou que a broca æpresentou melhor desenvolvimento em dieta à base de milho, cenoura em pó e caseína, do que em dieta natural (colmos de milho).

HENSLEY e HAMMOND (1968) apresentaram técnicas de criação de lagartas da broca-da-cana em laboratório, utilizando dietas artificiais. Constataram que a adição do germe de trigo à dieta deu origem a um meio de alto valor nutricional 
que propiciou o desenvolvimento de insetos comparáveis àqueles criados em cana ou milho.

O desenvolvimento de $D$. saccharalis foi acompanhado por VAN DITHER e GOOSSENS (1970), em nove dietas artificiais, contendo diferentes porcentagens de feijão, milho, cenoura e arroz. Os insetos foram mantidos em temperaturas e um $\underline{i}$ dades que variaram de 24 a $280^{\circ} \mathrm{C}$ e 65 a $90 \%$, respectivamente e fotofase de 12 horas. Os autores constataram que os insetos criados na dieta com $12 \%$ de feijão, 3,7\% de milho e 1,8\% de ce noura apresentaram alta viabilidade larval (81\%), elevado peso de pupas (machos e fêmeas), fêmeas mais férteis, as quais produziram em média 394 ovos com uma alta viabilidade (94\%), quan do comparada com as demais.

No Brasil, os trabalhos com dietas artificiais foram iniciados no Departamento de Entomologia da ESALQ, em Pi racicaba, SP, por GALLO et alii (1971). Estes autores utilizaram a dieta proposta por HENSLEY e HAMMOND (1968) com algumas modificações, para multiplicação de D. saccharalis, em um programa visando ao seu controle biológico, através de taquinídeos. A partir dai, outros trabalhos de pesquisa foram desenvolvidos, visando a criação desse lepidóptero no país. Assim, SGRILLO (1973) estudou a criação do inseto, em laboratório, com o objetivo de automatizar a distribuição da dieta e dos ovos, es colher técnicas de manuseio para os insetos e analisar custos da criação.

MENDONÇA FILHO (1973) descreveu a metodologia 
de criação de $D$. saccharalis em dieta artificial para produção de parasitóides, utilizada pelo PlANALSUCAR em Maceió, AL.

RISCO et alii (1973) criando a praga numa dieta artificial à base de fibra de cana e pó de cenoura, obtiveram uma porcentagem de 54,12\% de lagartas do $4 \%$ instar, aptas a se rem "inoculadas" com parasitóides da broca.

VILLACORTA e MAGRO (1975) descreveram uma metodologia de criação de $D$. saccharalis, em laboratório, com dieta artificial à base de feijão. Testando diferentes variedades de feijão como fonte de proteina, NOVARETTI e TERAN (1976) verificaram que na dieta com feijão branco, ocorreu um maior peso de pupas e maior porcentagem de brocas aptas para inoculação com parasitóides do inseto.

BREWER (1976) comparou dietas com diferentes fontes protéicas (feijão, caseina, germe de trigo, soja), discutindo os custos e qualidade destas dietas para D. saccharalis. O mesmo autor em 1977 observou que pantotenato de cálcio, niacina e riboflavina foram essenciais ao crescimento, desenvolvimento e reprodução do inseto.

KING et alii (1975), pesquisando a biologia de D. saccharalis em oito temperaturas constantes, 16,$6 ; 18,4 ; 22$; $26 ; 28 ; 30 ; 32$ e $34^{\circ} \mathrm{C}$, verificaram que houve um decréscimo do período de incubação com a elevação da temperatura até $32^{\circ} \mathrm{C}$. Com relação ao desenvolvimento do período larval, ocorreu um a longamento à temperatura de $22^{\circ} \mathrm{C}$, apresentando-se mais curto à $30^{\circ} \mathrm{C}$. Observaram ainda que a fase pupal foi menor à $33^{\circ} \mathrm{C}$, embo 
ra a esta temperatura tenha havido uma alta mortalidade. O peso de pupas foi maior à $22^{\circ} \mathrm{C}$, tanto para machos como para fêmeas. Os adultos apresentaram maior longevidade à $15,6^{\circ} \mathrm{C}$, enquanto as fêmeas produziram maior número de ovos à $24{ }^{\circ} \mathrm{C}$.

BREWER (1981) comparou duas dietas, uma à base de soja e óleo de milho e outra contendo soja e germe de trigo. As lagartas foram criadas à $29,5^{\circ} \mathrm{C}, 75 \%$ de umidade relativa e fotofase de 14 horas e os adultos à $24{ }^{\circ} \mathrm{C}, 80 \%$ de umidade relativa do ar e a mesma fotofase utilizada para lagartas. Pôde-se verificar, que os períodos larval e pupal foram menores nos insetos criados nas dietas à base de soja e óleo de milho, apresentando em média, durante 5 gerações, 30 e 8,4 dias, respectivamente. Com relação ao peso de pupas, estas também foram mais pesadas nessa dieta.

ROE et alii (1982), criando D. saccharalis em dieta à base de germe de trigo, caseina e farinha de milho, à $30^{\circ} \mathrm{C}$, observaram que o periodo larval constou de até sete instares, sendo que $28,3 \%$ das lagartas apresentaram 5 instares, 68,9\%, 6 instares e $2,8 \%, 7$ instares.

OSORES et alii (1982b) descreveram um método de criação da broca-da-cana-de-açúcar em meio artificial, visando a criação massal de parasitóides do inseto. Os insetos foram mantidos à $26 \pm 20^{\circ} \mathrm{C}$ e apresentaram um ciclo total médio de 45 dias. Segundo o autor, nestas condições, as lagartas com 18 dias estavam aptas para serem "inoculadas" com parasitóides. 


\title{
2.2. INFLUÊNCIA DOS FATORES ECOLÓGICOS SOBRE
}

\author{
D. saccharalis
}

WOLCOTT (1915) verificou em Porto Rico que a po pulação da broca-da-cana-de-açúcar está inversamente correlacionada com a precipitação pluviométrica, ocorrendo ataques mais severos nas regiões secas (pluviosidade média anual entre 600 e $750 \mathrm{~mm}$ ). Também na Guiana Inglesa foi observado que o nível de infestação da broca é menor na estação das chuvas do que no perído seco (BOX, 1925). A explicação para o fato, segundo este autor, é que os parasitóides de ovos apresentavam uma máxima e ficiência no período seco e eram exterminados no período de al ta pluviosidade.

Segundo PICKEL (1939) a população de D. saccharalis é influenciada pelas chuvas, entretanto, reconheceu não saber de que forma se manifestava esta interferência.

BERTELS (1970) verificou que a chuva influiu di retamente sobre a população da broca, de forma físico-mecānica e a temperatura e umidade relativa do ar também influiram na dinâmica populacional da praga, pois de um modo geral o tempo úmido e quente foi favorável ao aumento da população.

LARA (1974) estudando a influência dos fatores ecológicos na coleta de pragas com armadilhas luminosas, obser vou correlação inversa entre pressão barométrica e umidade relativa e coleta de adultos de $D$. saccharalis.

Através de levantamentos mensais em cinco re- 
giões canavieiras no Estado de Alagoas, durante todo o ciclo da cultura da cana-de-açúcar, MENDONÇA FILHO (1978) verificou que a precipitação pluviométrica afetou a população da praga em cana-soca; em cana-planta, no entanto, não foi abservada cor relação entre esse parâmetro climático e as formas imaturas do inseto.

A temperatura influi diretamente sobre $D$. saccharalis, afetando o seu desenvolvimento (HOLLOWAY e HALEY, 1927 ; BOX, 1952).

HAYWARD (1943) relatou que em Tucumān (Argentina), o ciclo biológico da broca-da-cana-de-açúcar é mais curto na época quente, havendo um alongamento no inverno. Segundo o autor, as lagartas são muito sensiveis às temperaturas abaixo de zero, chuvas excessivas e secas prolongadas. OSORES et alii (1982a), observaram que nesta Provincia Argentina D. saccharalis apresentou 5 gerações durante o ano, sendo que a 1ạ geração (outubro - dezembro) ocorreu em meses com temperaturas médias que variaram entre 21 e $250 \mathrm{C}$ e com pluviosidade entre 50 e $150 \mathrm{~mm}$. As 3 gerações seguintes (dezembro - janeiro, janeiro - março e março - abril) denominadas de verão, apresentaram uma duração média de 40 dias e neste período as temperaturas médias mensais e pluviosidades foram superiores à $22^{\circ} \mathrm{C}$ e $150 \mathrm{~mm}$, respectivamente. Na geração de inverno (abril - outubro) as tem peraturas médias mensais foram inferiores à $130^{\circ} \mathrm{C}$ e as pluviosidades menores que $40 \mathrm{~mm}$.

Nas condições do Estado de São Paulo a broca- 
-da-cana produz de 4 a 5 gerações, sendo uma geração de lagartas hibernantes (GALLO, 1964). Esse autor afirmou ainda que o período larval se completa em 23 a 64 dias, influindo muito nessa variação a temperatura do ambiente: com temperaturas médias mais elevadas $\left(28^{\circ} \mathrm{C}\right)$, o período é curto, enquanto que com temperaturas médias mais baixas $\left(20^{\circ} \mathrm{C}\right)$ o período é mais longo. Por outro lado, quando as condições térmicas situam-se abaixo de $180^{\circ} \mathrm{C}$, as lagartas entram em diapausa, fato que se nota para as condições desse Estado, com as lagartas eclodidas em abril maio.

Na Louisiana, FLOYD (1966) verificou que sob con dições de inverno rigoroso (temperatura abaixo de $-12^{\circ} \mathrm{C}$ ), a mor talidade da broca chega a ser de 100\%, enquanto CHARPENTIER et alii (1967) citaram esta mortalidade como sendo de 98\% e mencionaram que sob condições de temperaturas mais amenas, as lagartas conseguem atravessar o inverno em colmos velhos de milho. Por outro lado, HENSLEY (1971) relatou que temperaturas de inverno ao redor de $-70^{\circ} \mathrm{C}$ mataram mais de $80 \%$ da população.

Os trabalhos experimentais de KIRST e HENSLEY (1974) demonstraram que baixas temperaturas são um importante fator de decréscimo da população de lagartas de $D$. saccharalis, observando que o efeito de baixas temperaturas está mais relacionado com o número de dias nos quais a temperatura está abaixo de $0^{\circ} \mathrm{C}$ do que com pequenos períodos de temperaturas abaixo de $-60 \mathrm{C}$. Os autores não encontraram correlação entre os dados de pluviosidade semanal e a mortalidade larval. 
PRUNA (1969) fez uma ampla revisão de literatura sobre a broca-da-cana-de-açúcar, referente à biologia, e apontou a temperatura como um dos fatores que mais influi na du ração do ciclo de vida, o qual se prolonga à medida que a temperatura diminui. WALDER (1976) também observou que a temperatura e umidade do ar foram os fatores meteorológicos que mais influíram na população da praga.

Em estudos de flutuação populacional, SILVEIRA NETO (1972) verificou os efeitos da pressão barométrica, tempe ratura máxima, graus-dias e umidade relativa sobre a coleta de adultos de D. saccharalis.

MENDES (1976), estudando a influência dos elementos climáticos sobre a flutuação populacional da broca-da-cana, em Araras, SP, verificou que os adultos de D. saccharalis ocorreram em todos os meses do ano com um acme na 2 a quinzena de agosto e com dois picos secundários, um na 1ạ quinzena de janeiro e outro na 2 ạ quinzena de março. Este autor concluiu que os elementos meteorológicos explicaram 41,3\% da flutuação populacional da praga, sendo que a amplitude térmica foi o fator mais importante, com uma participação de $27,8 \%$

Vários estudos foram desenvolvidos com relação à diapausa da broca-da-cana-de-açúcar.

Assim, nos Estados Unidos, STUBBS e MORGAN (1902) e HOLLOWAY et alii (1928) sugeriram que lagartas por eles observadas estavam, provavelmente, num estágio de quiescên cia ou diapausa. 
KATYAR e LONG (1961) conduziram observações sobre a ocorrēncia de diapausa de $D$. saccharalis na Louisiana, durante o período de julho de 1959 a março de 1960, concluindo que no campo as lagartas em dianausa eram mais abundantes no perí do de outubro a dezembro. Verificaram ainda que o periodo da diapausa foi em torno de 3 meses.

Em Louisiana, Kurst (1.973), citado por OSMAN (1965), coletou mensalmente lagartas de broca (de dezembro de 1965 a março de 1966) e expōs estas formas imaturas a dois regimes de fotofases: 10 e 14 horas. Todos os insetos foram alimentados com dieta artificial e mantidos a uma temperatura de $21^{\circ} \mathrm{C}$. Lagartas coletadas em dezembro e janeiro e expostas a uma fotofase de 10 horas, exigiram um maior período (40 dias) para completar o desenvolvimento, quando comparadas àquelas expostas à 14 horas de luz. Por outro lado, não ocorreu diferença no período de desenvolvimento nas lagartas coletadas em fevereiro e março.

OSMAN (1975), criando em laboratório, lagartas coletadas no campo, em ciuas temperaturas $\left(21\right.$ e $260^{\circ}$ ) e: em duas fotofases (10 e 14 horas) verificou que aquelas criadas à $260^{\circ} \mathrm{C}$ e expostas à 10 horas de luz exigiram 2 dias a mais para completar a fase larval do que aquelas criadas à 14 horas de luz. Por outro lado, à $21^{\circ} \mathrm{C}$, as lagartas submetidas à 10 horas de luz, apresentaram um periodo larval de 36,5 dias a mais que as lagartas criadas com 14 horas de luz. Para o autor, isto indicou que o efeito do fotoperíodo sobre o desenvolvimento da bro 
ca foi mais pronunciado em baixas temperaturas.

Segundo FUCHS et alii (1979), populações de $D$. saccharalis, do Vale do Rio Grande (Texas - EUA), apresentaram diapausa facultativa no último instar larval. De acordo com os autores, a indução e término da diapausa são dependentes da tem peratura e fotoperiodo.

No Brasil a "diapausa" de D. saccharalis foi re ferida por BERGAMIN (1948), GALLO et alii (1970), WALDER (1976) e SGRILLO (1979). 
.18.

\section{MATERIAL E MÉTODOS}

A pesquisa foi desenvolvida nos laboratórios de Biologia do Departamento de Entomologia da ESALQ/USP, em Piracicaba, SP, com Diatraea saccharalis (Fabricius, 1794) (Lepidoptera - Pyralidae).

\subsection{COLÔNIA INICIAL DE INSETOS}

A pesquisa foi iniciada a partir de ovos provenientes do laboratório de criação massal de $D$. saccharalis da Companhia Industrial e Agrícola de Santa Bärbara D'Deste, sendo a técnica utilizada para a criação deste lepidóptero semelhante à descrita por MENDES (1980).

Os ovos foram mantidos em placas de Petri $110 \mathrm{~cm}$ de diâmetro x 2,0 cm de altura) forradas com papel de filtro u 
medecido com āgua destilada; uniram-se tampa com tampa ou fundo com fundo destas placas para permitir a vedação do conjunto com fita adesiva, sendo a seguir colocados em câmara climatiza da modelo BOD $347 \mathrm{G}$ da FANEM, regulada à $300^{\circ}$, umidade relativa de $70 \pm 10 \%$ e fotofase de 14 horas, até a eclosão das lagar tas.

\subsection{BIOLOGIA EM DIFERENTES TEMPERATURAS}

A biologia de $D$. saccharalis foi conduzida em câmaras climatizadas (idênticas àquelas descritas no item 3.1.), reguladas à $20,22,25,30$ e $32^{\circ} \mathrm{C}, \quad$ umidade relativa de $70 \pm 10 \%$ e fotofase de 14 horas.

Em cada temperatura, foram observados os seguin tes parâmetros do ciclo biológico do inseto:

a) Fase de ovo:

- período de incubação

- viabilidade

b) Fase de lagarta:

- duração total da fase

- número de instares

- duração dos instares 
- viabilidade por instar

- viabilidade total

c) Fase de pupa:

- duração da fase

- peso de machos e fêmeas

- viabilidade

- razão sexual, calculada através da fórmula: $r s=\frac{q}{q+0^{\circ}}$

d) Fase adulta:

- período de pré-oviposição

- período de oviposição

- número de posturas por fêmea

- número de ovos por postura

- nümero total de ovos por fêmea

- longevidade de machos e fêmeas

- porcentagem de deformação

- pós-ovi posição

3.2.1. TÉCNICA DE CRIAÇÃO DE D. saccharalis

3.2.1.1. Fase de lagarta

Em cada temperatura, lagartas recém-eclodidas, retiradas da colônia inicial, foram transferidas, individual- 
mente, para 160 tubos de vidro $(2,5 \mathrm{~cm}$ de diāmetro $\mathrm{x} 8,5 \mathrm{~cm}$ de altura), previamente esterilizados, contendo dieta artificial, desenvolvida por HENSLEY e HAMMOND (1968). O preparo do meio artificial, transferência de lagartas e cuidados assépticos fo ram feitos segundo PARRA (1979). Os tubos de criação foram tam pädos com algodão hidrófobo esterilizado e mantidos em suportes de arame com a extremidade superior voltada para baixo, pa ra reduzir a contaminação por microrganismos. As layartas eram observadas diariamente e as mortas eliminadas, após a medição da cépsula cefälica.

Para avaliação do nūmero de instares larvais, foi feita a medição da largura da cápsula cefálica de 25 lagartas, previamen te escolhidas, para cada tratamento. As mediçōes foram feitas através de uma ocular graduada BAUSCH \& LOMB, acoplada a um mi croscópio-estereoscópico WILD M4A.

\subsubsection{Fase de oupa}

Assim que se ảava a transformação, cada pupa ob tida era transferida para um tubo de vidro semelhante ao utili zado para criação de lagartas, o qual era tampado com algodão hidrófobo e devidamente identificado. As pupas com 24 horas de idade, foram pesadas em uma balança METTLER H7, com aproximação até centésimo de grama e separadas por sexo, segundo BUTT e CANTU (1962). A seguir, as pupas eram recolocadas nos tubos 
de vidro e ai mantidas até a emergência dos adultos.

\subsubsection{Fase adulta}

Após a emergência, para ambos os sexos, foi ano tado o número de individuos que apresentavam asas anormais.

Para observações da fase adulta, machos e fêe meas nascidos no mesmo dia, com idade entre 8 e 10 horas, eram colocados na proporção indicada por MISKIMEN (1965), de 2 ma chos para uma fêmea, em gaiolas, para acasalamento. Estas gaio las consistiram de tubos de PVC com $10 \mathrm{~cm}$ de diāmetro e $22 \mathrm{~cm}$ de altura, fechadas nas extremidades com placas de petri de $16 \mathrm{~cm}$ de diāmetro. A placa colocada na parte inferior era revestida com papel de filtro. As paredes internas da gaiola foram revestidas com papel sulfite com a finalidade de proporcio nar um local adequado de postura (MENDES et a $i$ i, 1977; MENDES, 1980). Diariamente, o papel de filtro e o sulfite eram umedecidos com água destilada. A umidade no interior de gaiolas foi medida, quando necessária, através de pares termoelétricos (co bre-constantan) à semelhança de um conjunto psicrométrico. Assim, para funcionar como bulbo úmido, um dos pares era envolvi do com gaze umedecida, sendo que o outro par funcionava como bulbo seco.

Os adultos foram alimentados com solução aquosa de mel à 10\%, fornecida por canilaridade, através de um rolo dental "Johnson's", mantio em copos plásticos. o alimento era 
renovado a intervalos de dois dias, tempo suficiente para que não fermentasse.

Para cada temperatura, estudaram-se 15 casais com observações diārias de toda a fase.

\subsubsection{Fase de ovo}

As massas de ovos obtidas no papel sulfite eram retiradas diariamente das gaiolas, esterilizadas externamente com solução de formaldeído à $5 \%$ por 5 minutos e, posteriormente, lavadas com água destilada por mais 5 minutos, sendo a seguir colocadas para secar. Recortavam-se então, pedaços de papel sulfite, contendo aproximadamente 25 ovos por massa, mantendo-os em placas de Petri revestidas internamente com papel de filtro umedecido.

Para aumentar a precisão e por facilidade de ma nuseio e visualização, a contagem dos ovos foi efetuada no final do desenvolvimento embrionário, quando era visível a cabeça da lagarta (pontos escuros). A determinação do período de incubação e viabilidade aos ovos originados de adultos criados em diferentes temperaturas, foi feita através das contagens diārias das lagartas eclodidas, em todas as posturas. 


\subsection{TABELA DE VIDA DE FERTILIDADE}

Com os resultados obtidos nas diferentes temperaturas, foram elaboradas as tabelas de vida de fertilidade, sendo os valores das colunas $(x, m x, l x)$ e os indices $\left(R_{O^{\prime}} T\right.$, $r_{m}$ e $\lambda$ ) calculados segundo SILVEIRA NETO et alii (1976), como segue:

- $\mathbf{x}=$ intervalo de tempo no qual foi tomada a amostra;

- $\mathrm{mx}=$ fertilidade específica - número de descendentes produzidos no estágio por fêmea e que darão fêmeas. Portanto, é calculada em função da razão sexual;

- $\ell x=$ taxa de sobrevivência.

$$
\text { Baseando-se nestes dados, foram calculados os }
$$

indices:

- $\mathrm{R}_{0}=$ taxa líquida de reprodução, onde $\mathrm{R}_{0}=\sum$ mx $: \ell \mathbf{x} ;$

- $T$ = duração média de uma geração, onde:

$$
\mathrm{T}=\frac{\sum \mathrm{mx} \cdot \mathrm{lx} \cdot \mathrm{x}}{\mathrm{R}_{\mathrm{O}}}
$$

- $r_{m}=$ capacidade de aumentar em nümero, onde $r_{m}=\frac{R_{0}}{T}$;

- $\lambda=$ razão finita de aumento, onde $\lambda=e^{r_{m}}$. 


\subsection{ANÁlise ESTATÍSTICA DOS DADOS BIOLÓgICOS OBTIDOS}

Os dados biológicos de D. saccharalis obtidos em condições de laboratório, foram analisados através da estatistica não-paramétrica, utilizando-se o teste de Kruskal-Wallis (CAMPOS, 1979), senco as médias comparadas pelo teste não-paramétrico de Comparações Múltiplas, ao nível de 5\% de proba bilidade.

Estimaram-se, com os dadäs biológicos das diferentes temperaturas, as transformações de 50\% da população em pupas e adultos $\left(\mathrm{T}_{50}\right)$, nos diferentes tratamentos, sendo os re sultados obtidos ajustados às equações logísticas adequadas.

\subsection{Determinaç̃o DA CONSTANTE TÉRMiCA}

Os limiares de desenvolvimento (temperaturas ba ses) para as fases de ovo, lagarta, pupa e adulto de $D$. sacch $\underline{a}$ ralis foram estimados pelo método do coeficiente de variação (CV), proposto por ARNOLD (1959), que consiste na determinação da constante térmica (K) em cada temperatura, em função da atribuição de valores arbitrários de limiar de desenvolvimento. O mais baixo CV encontrado entre os quatro valores de $\mathrm{K}\left(\mathrm{K}_{20}\right.$, $\mathrm{K}_{22}, \mathrm{~K}_{25}, \mathrm{~K}_{30}$ ) correspondeu à temperatura base.

Os cálculos de determinação dos limiares de desenvolvimento das fases de ovo, lagarta, pupa e adulto basea- 
ram-se nos resultados obtidos à $20,22,25$ e $30^{\circ} \mathrm{C}$, não sendo computado neste cálculo aqueles registrados à $32^{\circ} \mathrm{C}$, uma vez que esta temperatura foi inadequada ao desenvolvimento do inseto.

A constante térmica foi estimada conforme SILVEIRA NETO et alii (1976) pela fórmula $\mathrm{K}=\mathrm{y}(\mathrm{t}-\mathrm{a})$, onde $\mathrm{K}=$ constante térmica (graus-dias), $y=$ tempo de desenvolvimento (dias), $t=$ temperatura ambiente $(O C), a=$ temperatura base $(O C)$.

3.6. Determinação do número de gerações de D. saccharalis, COM BASE NAS SUAS EXIGÊMCIAS TÉRMICAS, EM QUATRO LOCALIDADES CANAVIEIRAS DO ESTADO DE SÃO PAULO

O número provável de gerações de $D$. saccharalis foi est.imado em quatro locais do Estado de São Paulo, tomando-se como base as exigências térmicas da praga, determinadas em condições de laboratório (item 3.5.). Estes locais foram escoIhidos (Figura 1) por serem representativos de regiões cana vieiras do Estado e por apresentarem dados climatológicos consistentes.

Utilizaram-se as temperaturas médias diárias de 1970 a 1982, para os municípios de Pindorama, Jaú e Ribeirão Preto, obtidas no arquivo de dados da Seção de Climatologia Agrícola do Instituto Agronômico de Campinas, e a média mensal de 1917 a 1970 para o municipio de Piracicaba, obtida através do Departamento de Física e Meteorologia da ESALQ. 
o número de gerações foi calculado baseando-se em PARRA (1981), sendo que o início da contagem deste número foi feito a partir do pico populacional de adultos de $D$. saccharalis em cada área. Este pico foi determinado baseando-se em estudos com armadilhas luminosas, modelo "Luiz de Queiroz", providas de lâmpadas fluorescentes ultravioletas, mödelo F15T8BL da General Electric, realizados pelo PLANALSUCAR - Seção de En tomologia - Araras, SP, no pertodo de 1976-1982. Nas quatro re giões analisadas este pico correspondeu ao mês de agosto. Para os cálculos dos graus-dias (acumulações diárias), utilizou-se o computador COMMODORE-CBM-MODEL 3032, I inguagem BASIC, do Centro de Energia Nuclear na Agricultura (CENA), em Piracicaba, SP. Como para Piracicaba não foi possivel a obtenção dos dados diários de temperatura, considerou-se que todos os dias de cada mês apresentavam temperatura idêntica à tem peratura média do mês considerado. 


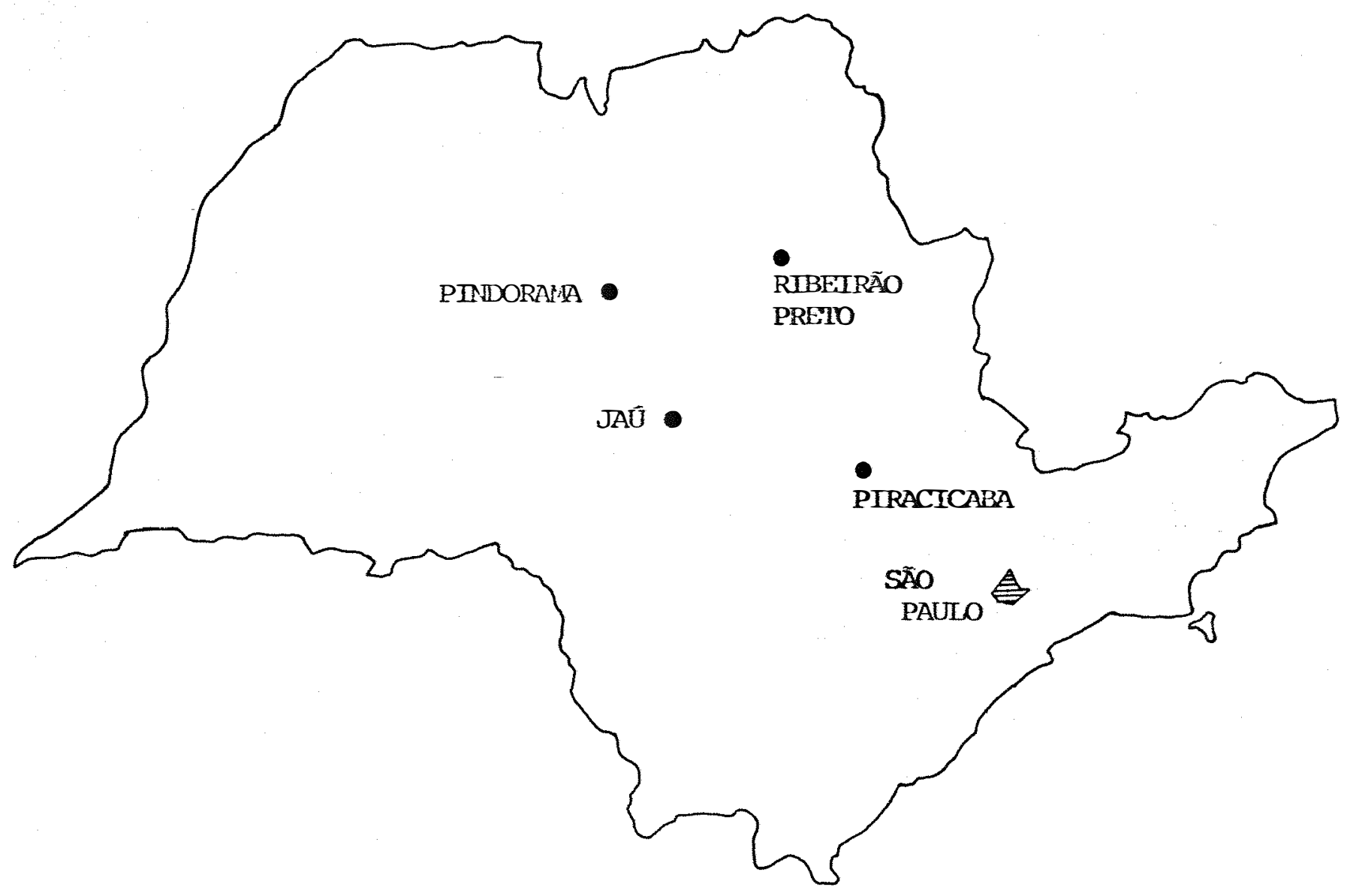

Figura 1 - Localidades do Estado de São Paulo, selecionadas para detennina ção do número de gerações anuais de $D$. saccharalis, cam base enı suas exigências térnicas. 


\title{
4. RESULTADOS E DISCUSSÃO
}

\author{
4.1. FASE DE OVO
}

o período médio de incubação e respectiva viabilidade de ovos de Diatraea saccharalis (Fabricius, 1794), obtidos nas diferentes temperaturas encontram-se na Tabela 1 . O período de incubação foi decrescente com o aumento da temperatura, coinci dindo com os dados de KING et alii (1975). Os valores médios ob tidos na presente pesquisa à 25 e $30^{\circ} \mathrm{C}$, se aproximam daqueles obtidos por BOWLING (1967) e WALKER (1968) em temperaturas de $26,5 \pm 1,5^{\circ} \mathrm{C}$ e $29,4^{\circ} \mathrm{C}$, respectivamente.

A porcentagem de eclosão obtida nas diferentes temperaturas foi bastante variável (Tabela 1), obtendo-se a maior viabilidade à $30^{\circ} \mathrm{C}$ e a menor à $22^{\circ} \mathrm{C}$. Os resultados obser vados por KING et alii (1975) também oscilaram com a variação de temperatura, sendo que estes autores obtiveram uma maior por 
Tabela 1 - Período de incubação e viabilidade dos ovos na colônia inicial* de $D$. saccharalis, em cinco temperaturas. UR: $70 \pm 10 \%$ e fotofa se: 14 horas.

Temperatura

$\left({ }^{\circ} \mathrm{C}\right)$

20

22

25

30

32
Período de incubação** (dias) viabilidade

$(\%)$

$\begin{array}{ccc}10,60 \pm 0,24 \mathrm{a} & 78,20 \\ 22 & 7,23 \pm 0,21 \mathrm{ab} & 70,10 \\ 25 & 6,08 \pm 0,12 \mathrm{abc} & 81,80 \\ 30 & 4,91 \pm 0,16 \mathrm{bc} & 86,70 \\ 32 & 4,27 \pm 0,23 \mathrm{c} & 76,90\end{array}$

* Insetos mantidos em meio artificial à $27 \pm 20 \mathrm{C}$; UR: $70 \pm 10 \%$ e fotofase: 14 horas.

** Médias seguidas da mesma letra, não diferem entre si, pelo teste não-paramétrico de Comparações Mültiplas, ao nível de 5\% de probabilidade.

centagem de eclosão à $26^{\circ} \mathrm{C}(98,6 \%)$, enquanto que à $34^{\circ} \mathrm{C}$ a viabilidade obtida foi de $10 \%$, mostrando o seu efeito adverso no desenvolvimento embrionário do inseto. Os resultados obtidos na presente pesquisa e aqueles de KING et alii (1975) sugerem que a faixa de desenvolvimento da broca-da-cana é mais ampla do que entre 20 e $34^{\circ} \mathrm{C}$. Pela baixa viabilidade obtida por KING et alii (1975) à $34{ }^{\circ} \mathrm{C}$, é de se supor que o limite superior esteja próximo deste valor. Entretanto, como na presente pesquisa à $200^{\circ}$ foi obtida uma alta viabilidade $(78,2 \%)$, o limite infe 
rior deve estar bem aquém desta temperatura.

Em termos gerais, a viabilidade em laboratório nas diferentes temperaturas, foi próxima à obtida por ARAÚJO et alii (1982), ou seja, 80,80\% e superior àquela encontrada por GUEVARA (1976) $(68,4 \%)$, ambos em estudos de biologia desen volvidos em condições de campo.

\subsection{FASE DE LAGARTA}

\subsubsection{DURAÇÃO E VIABILIDADE}

Os valores médios da duração da fase larval, bem como a viabilidade obtida nas diferentes temperaturas são apresentados na Tabela 2 .

Houve diminuição no período larval médio com a elevação da temperatura, dentro do intervalo de 20 a $32{ }^{\circ} \mathrm{C}$; esta tendência também foi observada por KING et alii (1975), embora estes autores tenham encontrado valores menores com relação à duração à $300^{\circ} \mathrm{C}$ e superiores à $22^{\circ} \mathrm{C}$. Essas variações talvez possam ser explicadas pelas diferenças de "strains" utilizados, desde que as dietas utilizadas foram semelhantes e em ambas as pesquisas os insetos foram mantidos em temperaturas constantes. Essas diferenças de "strains" chegam a ser bastante grandes pois HENSLEY (1969), trabalhando com populações de 
D. saccharalis de Porto Rico e Louisiana, observou diferenças nas exigências nutricionais dos insetos dos dois locais.

Tabela 2 - Duração média, viabilidade da fase larval de D. saccharalis, criada em dieta artificial em cinco temperaturas, com a respectiva contaminação* por tratamento. UR: $70 \pm 10 \%$ e fotofase: 14 ho ras.

\begin{tabular}{ccccc}
\hline $\begin{array}{c}\text { Terqeratura } \\
(\text { C })\end{array}$ & $\begin{array}{c}\text { Intévalo de } \\
\text { variação } \\
\text { (dias) }\end{array}$ & $\begin{array}{c}\text { Duração** } \\
\text { (dias) }\end{array}$ & $\begin{array}{c}\text { Viabili- } \\
\text { dade } \\
\left(\frac{\circ}{0}\right)\end{array}$ & $\begin{array}{c}\text { Contami } \\
\text { nação } \\
\left(\frac{\circ}{0}\right)\end{array}$ \\
\hline 20 & $34-76$ & $45,40 \pm 0,94 \mathrm{a}$ & 77,50 & 5,00 \\
22 & $23-59$ & $29,78 \pm 0,55 \mathrm{~b}$ & 71,00 & 4,50 \\
25 & $20-49$ & $27,84 \pm 0,62 \mathrm{~b}$ & 81,25 & 6,50 \\
30 & $15-44$ & $24,78 \pm 0,62 \mathrm{c}$ & 85,60 & 3,50 \\
32 & $16-39$ & $22,89 \pm 0,50 \mathrm{c}$ & 60,60 & 1,00 \\
\hline
\end{tabular}

* Aspergillus spp.

** Médias seguidas da mesma letra não diferem entre si, pelo teste não-paramétrico de Comparações Múltiplas, ao nível de 5\% de probabilidade.

Os dados divergentes com a literatura em relação à influência da temperatura no desenvolvimento larval do inseto podem ser atribuidos a diferentes meios artificiais uti lizados para a criação, por se tratarem de populações ("strains") diferentes de $D$. saccharalis ou pela manutenção dos insetos em diferentes condições ambientais.

Assim, BOWLING (1967) estudando a biologia da 
broca-da-cana em dieta à base de feijão, em temperatura de $26,5 \pm 1,5^{\circ} \mathrm{C}$, encontrou uma fase larval de 30,1 dias, sendo que BREWER (1981) obteve duração larval de 30,37 dias à 29,50C crian do o inseto em dieta à base de soja e óleo de milho, durações longas se comparadas com os resultados obtidos nesse trabalho. De uma maneira geral, entretanto, a literatura demonstra que 으 corre uma diminuição da fase larval com o aumento da temperatü ra (MEADOWS, 1938; RISCO, 1959; BERGAMIN, 1948; BERTELS, 1970).

A viabilidade larval foi maior à $300 \mathrm{C}$ e atingiu o menor valor à $32^{\circ} \mathrm{C}$ (Tabela 2) concordando com KING et ali (1975). A baixa viabilidade obtida na temperatura de $32^{\circ} \mathrm{C}$ pode ter sido influenciada pelo rápido ressecamento da dieta nesta temperatura. Alëm disto, em observações realizadas durante o trabalho, constatou-se que ocorria condensação nas paredes do tubo de criação a qual provocava uma alta mortalidade (por "afogamento") das lagartas do 10 instar. Este fato jā fora ressaltado por MISKIMEN (1965), o qual relatou que lagartas do 1 ? e 2\% Instares exigem umidac̈e abaixo de 85\%, para não morrerem por "afogamento"; a partir do 30 instar, entretanto, a umidade pode chegar à $90 \%$ sem afetar o normal desenvolvimento da lagar ta. Um outro fato que pode ter provocado morte de lagartas foi a ocorrência de rāpida oxidação dạ dieta mantida à $32^{\circ} \mathrm{C}$ (carac terizada pelo seu escurecimentol o que pode ter influenciado a fagoestimulação de lagartas do 1 Q ínstar.

Observou-se maior contaminação por microrganis mos, especialmente Aspergizlus spp., nas dietas mantidasà 25\% , 
sendo esta contaminação decrescente com o aumento da temperatu ra, a partir deste nível térmico Esta porcentagem de contaminação foi pequena, se comparada com HENSLEY e HAMMOND (1968), que observaram uma contaminação de 11\% em criação de $D$. saccha ralis mantida à $25 \pm 10^{\circ} \mathrm{C}$ e em relação a $\mathrm{ROE}$ et alii (1982) que à $27 \pm 10 \mathrm{C}$ obtiveram $16,2 \%$ de contaminação de Aspergi żus spp., em dieta semelhante à utilizada no presente trabalho. Tomando-se por base os resultados obtidos, sugere-se que sejam feitos estudos para se determinar as causas da contaminação nas baixas temperaturas, especialmiente à $25^{\circ} \mathrm{C}$, pois estes resultados contrariam aqueles obtidos por FERRAZ (1982) com spodoptera frugi perda (J.E. Smith, 1797), onde as maiores contarinaçōes foram regis tradas nas temperaturas mais elevadas.

\subsubsection{NÚMERO, DURAÇ̃̃O E VIABILIDADE DOS ÍNSTARES LARVAIS}

As larguras das cāpsulas cefálicas, o número de instares, duração e viabilidade de cada instar, com as respectivas razōes de crescimento, nas diferentes temperaturas estudadas, encontram-se nas Tabelas $3,4,5,6$ e 7 . O número de ec dises de D. saccharalis foi influenciado pela temperatura. Assim, à 20 e $22^{\circ} \mathrm{C}$ todas as lagartas apresentaram 6 instares, com um alongamento da duração de cada instar. Por outro lado, à 25, 30 e $320 \mathrm{C}$ as lagartas apresentaram 5 ou 6 instares. Nestas tem 
peraturas, houve predominância de lagartas com 6 instares, sen do a porcentagem de indivíduos com 5 instares variável de 5 , 20 ou $16 \%$ à 25,30 e $32^{\circ} \mathrm{C}$, respectivamente (Tabelas 5,6 e.7). Variações no número de instares, em função da temperatura, foram também observados por KING et alii (1975) e ROE et alii $(1982)$.

A razão de crescimento obtida em cada temperatu ra encontra-se no intervalo estabelecido por DYAR (1890) ou se ja de 1,1 a 1,9, e é semelhante aos resultados obtidos por ROE et alii (1982).

A mortalidade foi maior no último instar larval principalmente à 20 e $22^{\circ} \mathrm{C}$ (Tabelas 3 e 4 ), embora tenha havido uma baixa viabilidade no 1 o instar à $32^{\circ} \mathrm{C}$. Uma das causas da mortalidade nas temperaturas mais baixas $\left(20\right.$ e $\left.22^{\circ} \mathrm{C}\right)$ pode ser explicado pela contaminação da dieta, por microrganismos, pois como o período de desenvolvimento foi muito longo nestas tempe raturas, e como havia manipulação constante dos insetos para observação, foram criadas condições para maior contaminação nos tubos de criação. Um outro fator que pode ter ocasionado a mor talidade dos insetos, foi a manipulação no final do seu desenvolvimento. As lagartas, em função do seu hábito natural, péne tram na dieta a partir do 20 instar e, na sua grande maioria, pupam no interior do meio artificial; durante as observações, visando verificar a sua pupação, elas eram desalojadas e isto 
.36 .

talvez tenha afetado o seu comportamento, uma vez que após a manipulação deixavam de se alimentar e muitas vezes não chegaram a pupar. 


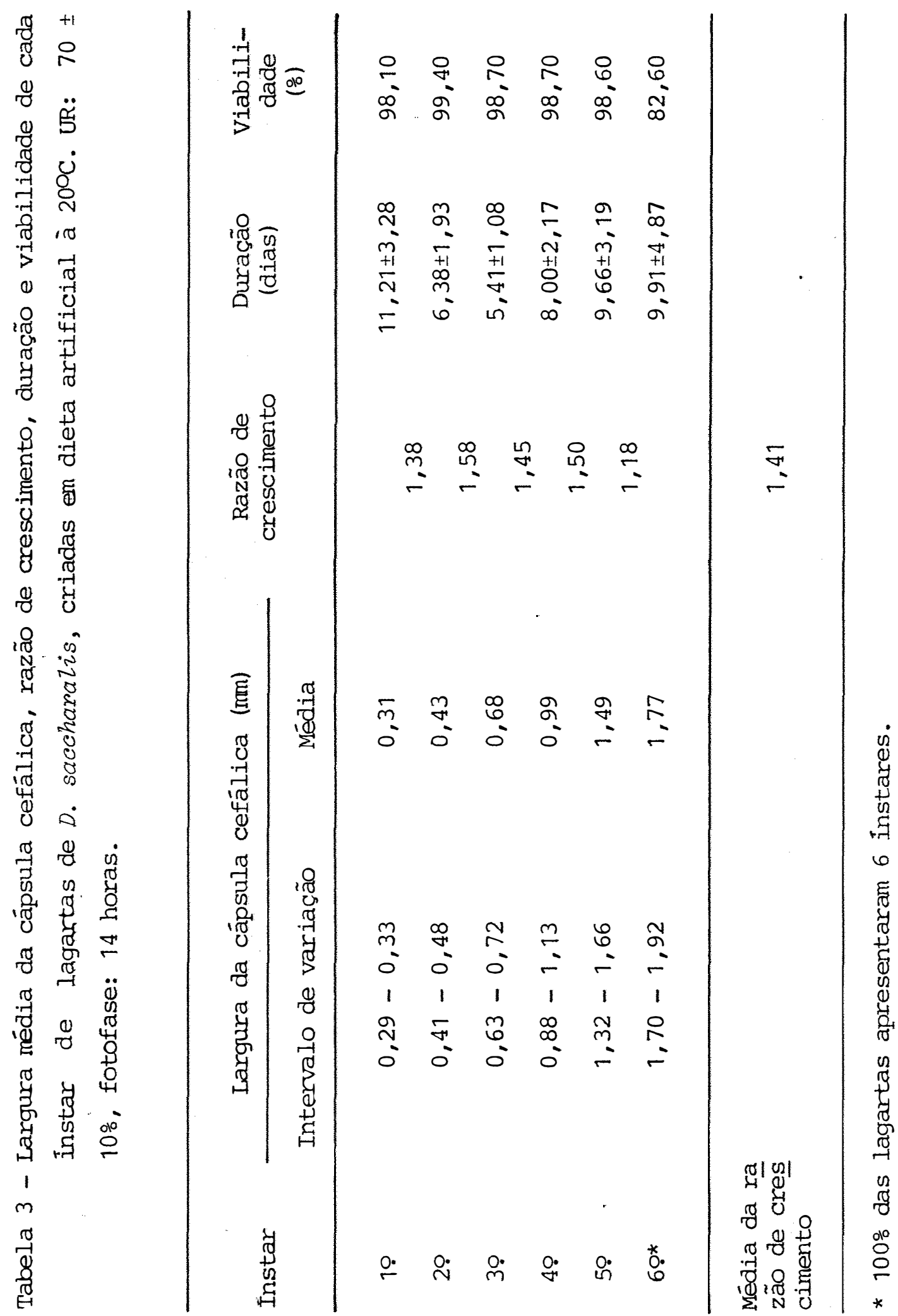




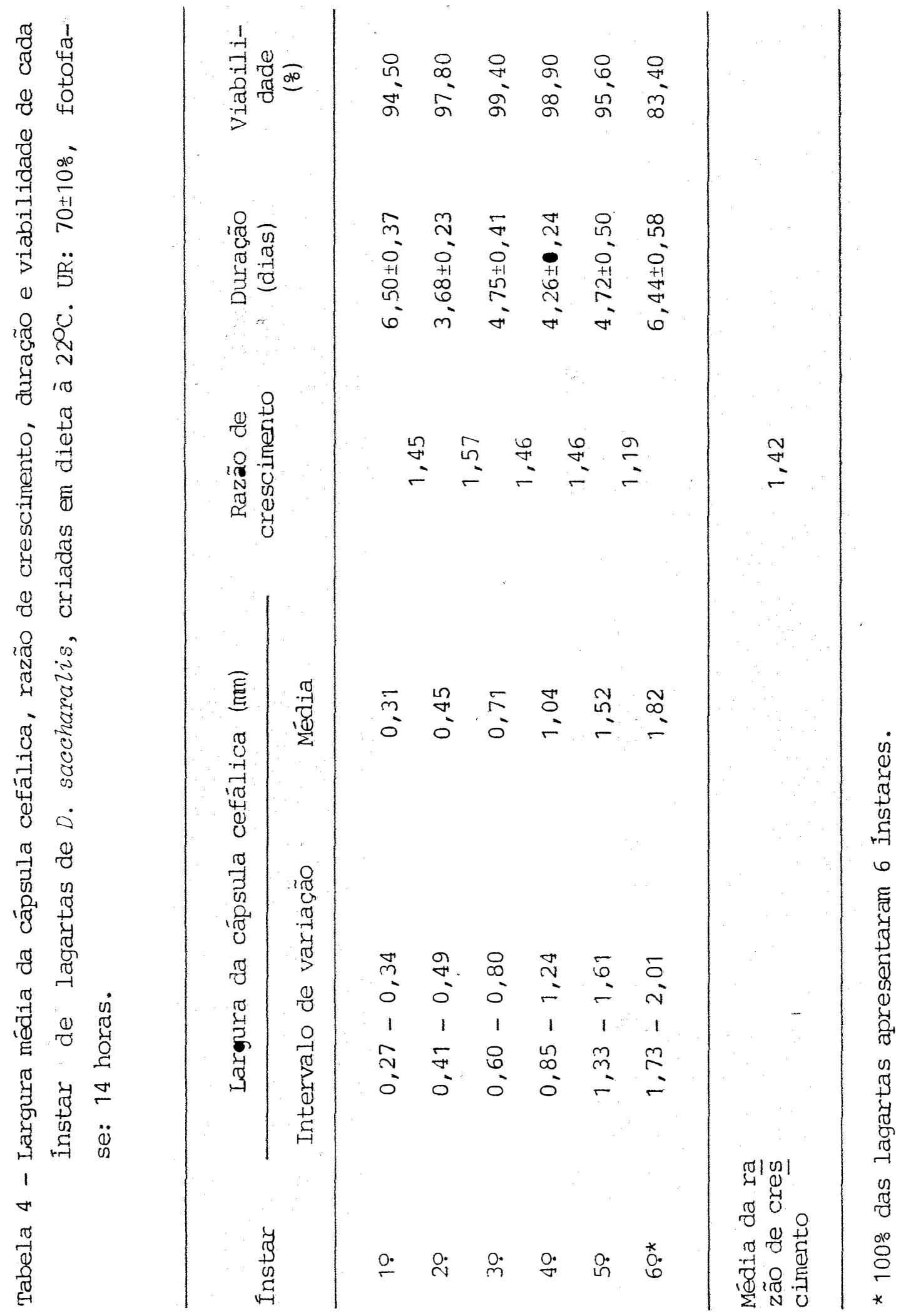




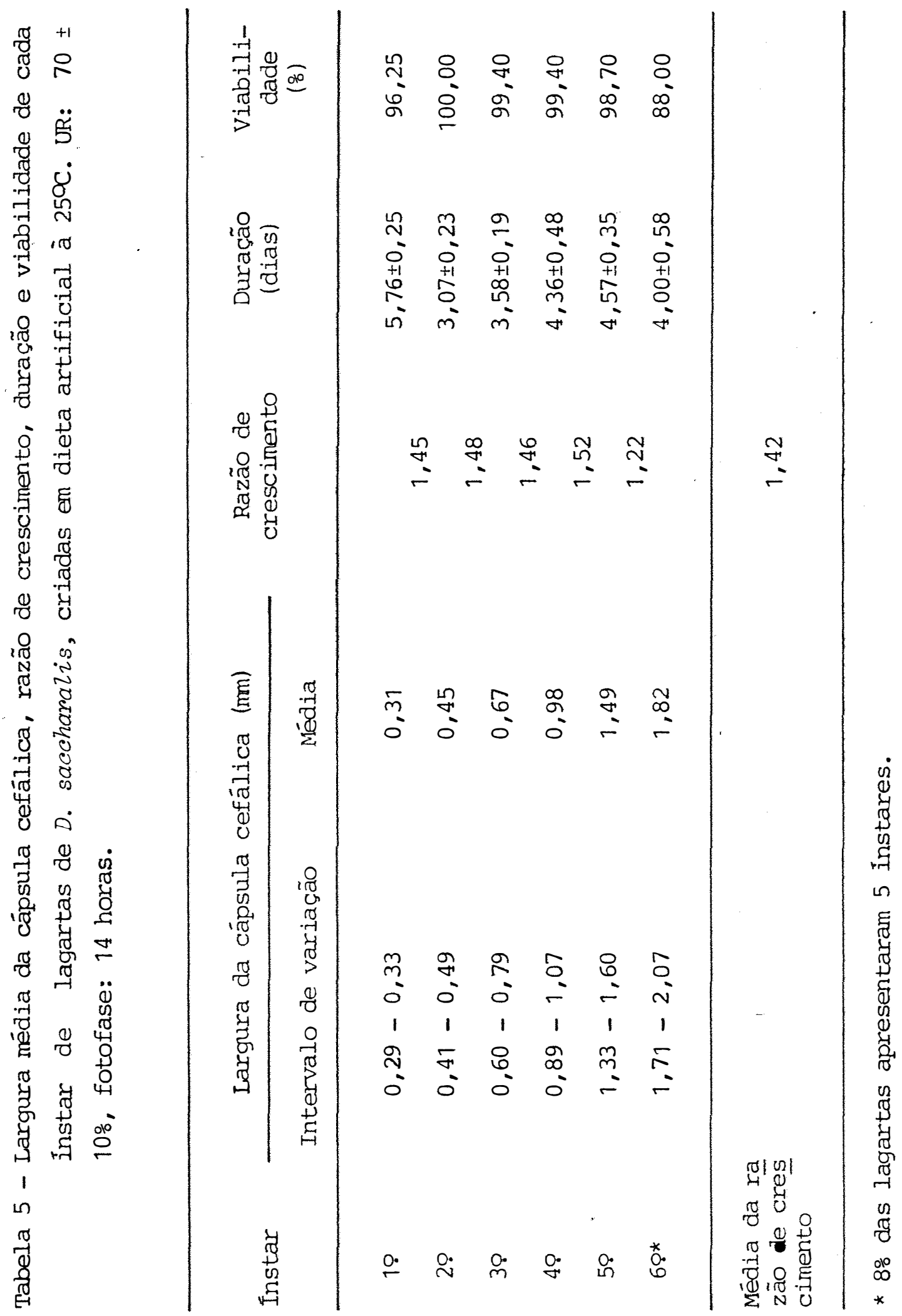


.40 .

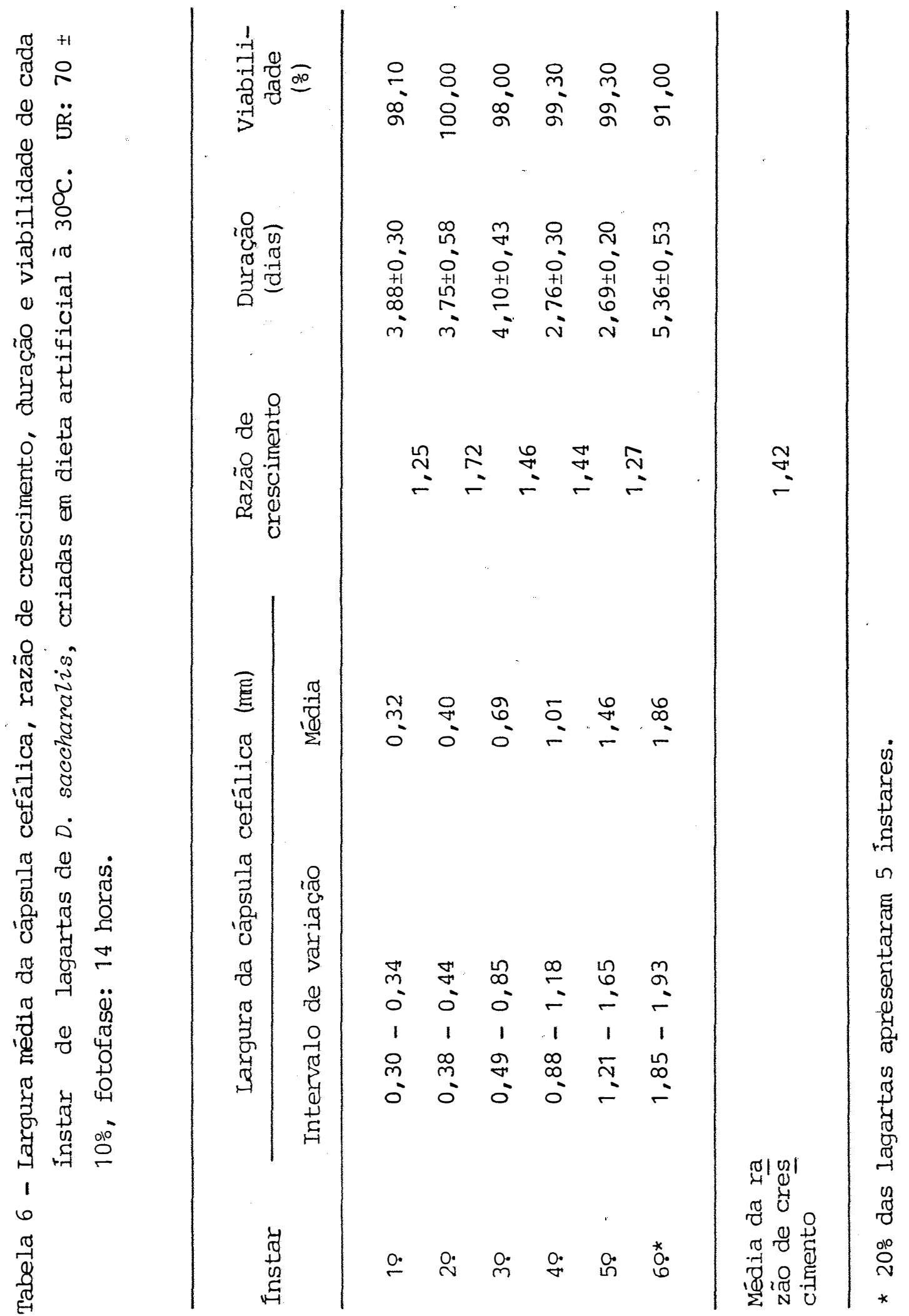




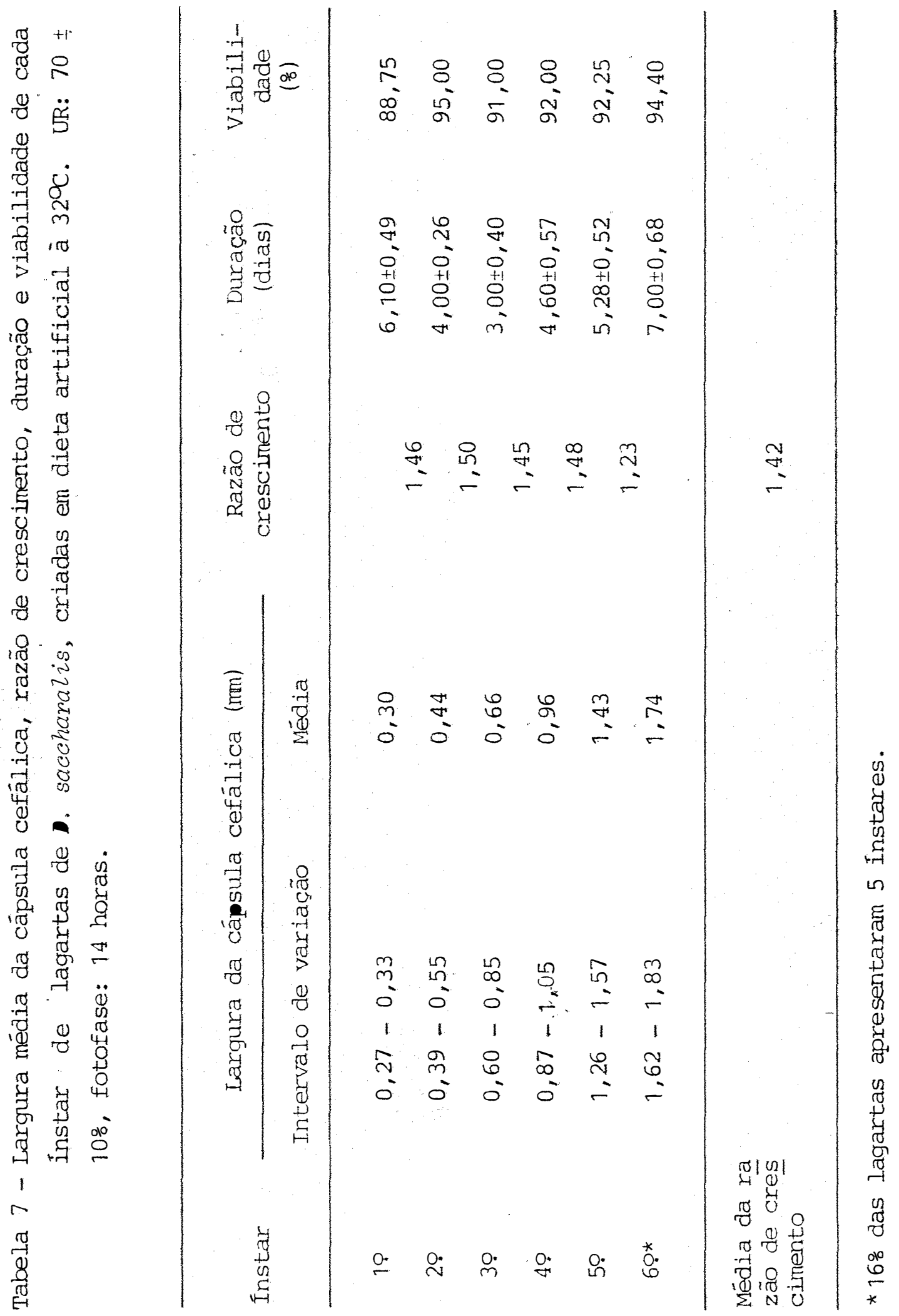




\subsection{FASE DE PUPA}

\subsubsection{DURACÃO, PESO E VIABILIDADE}

O periodo pupal para ambos os sexos de $D$. saccharalis foi afetado pela temperatura; decresceu com a elevação térmica até $30^{\circ} \mathrm{C}$ (Tabela 8) sendo que à $32^{\circ} \mathrm{C}$ houve um aumento da fase para machos e fêmeas. Tal tendência foi observada por KING et alii (1975), os quais verificaram que à $33^{\circ} \mathrm{C}$ O periodo pupal é de 7,9 e 7,3 dias para machos e fêmeas, respec tivamente. De uma maneira geral, observou-se que a duração da fase pupal nas diferentes temperaturas foi maior para fêmeas sendo marcadamente superior à $20^{\circ} \mathrm{C}$. Esta diferença não foi observada pelos autores anteriormentecitados.

As pupas fêmeas foram sempre mais pesadas que os machos (Tabela 8 ) sendo a diferença entre 45 e 63\%. Tal di ferença foi observada por SANTA CRUz et alii (1964), BOWLING (1967), KING et alii (1975) e BREWER (1976), sendo que ROE et alii (1982), relataram que essa diferença entre o peso de machos e fêmeas já pode ser observado no último instar larval, onde as lagartas que originarão fêmeas são 1,53 vezes mais pesadas que aquelias que vão dar origem a machos.

Não houve diferença significativa no peso das pupas, para ambos os sexos, no intervalo de 20 a $30^{\circ} \mathrm{C}$, embora tenham-se obtido fêmeas mais pesadas à $250 \mathrm{C}$. Por outro lado, à $32^{\circ} \mathrm{C}$ observou-se que tanto os machos como as fêmeas apresenta 
ram menor peso, demonstrando desta forma, que terperaturas acima de $30^{\circ} \mathrm{C}$ influenciam o desenvolvimento do inseto, o que concorda com KING et alii (1975) que verificaram que à $33^{\circ} \mathrm{C}$ as pu pas foram mais leves, para ambos os sexos.

A viabilidade pupal foi maior à $22^{\circ} \mathrm{C}$, ficando estável entre 25 e $30^{\circ} \mathrm{C}$ (Tabela 8 ). Houve diminuição da viabilidade à $22^{\circ} \mathrm{C}$, sendo, no entanto, mais drástica no limite supe rior $\left(32^{\circ} \mathrm{C}\right)$. Esses resultados comprovam as observações de KING et alii (1975), embora estes autores tenham obtido maior morta lidade pupal no intervalo de 28 e $33^{\circ} \mathrm{C}$. 


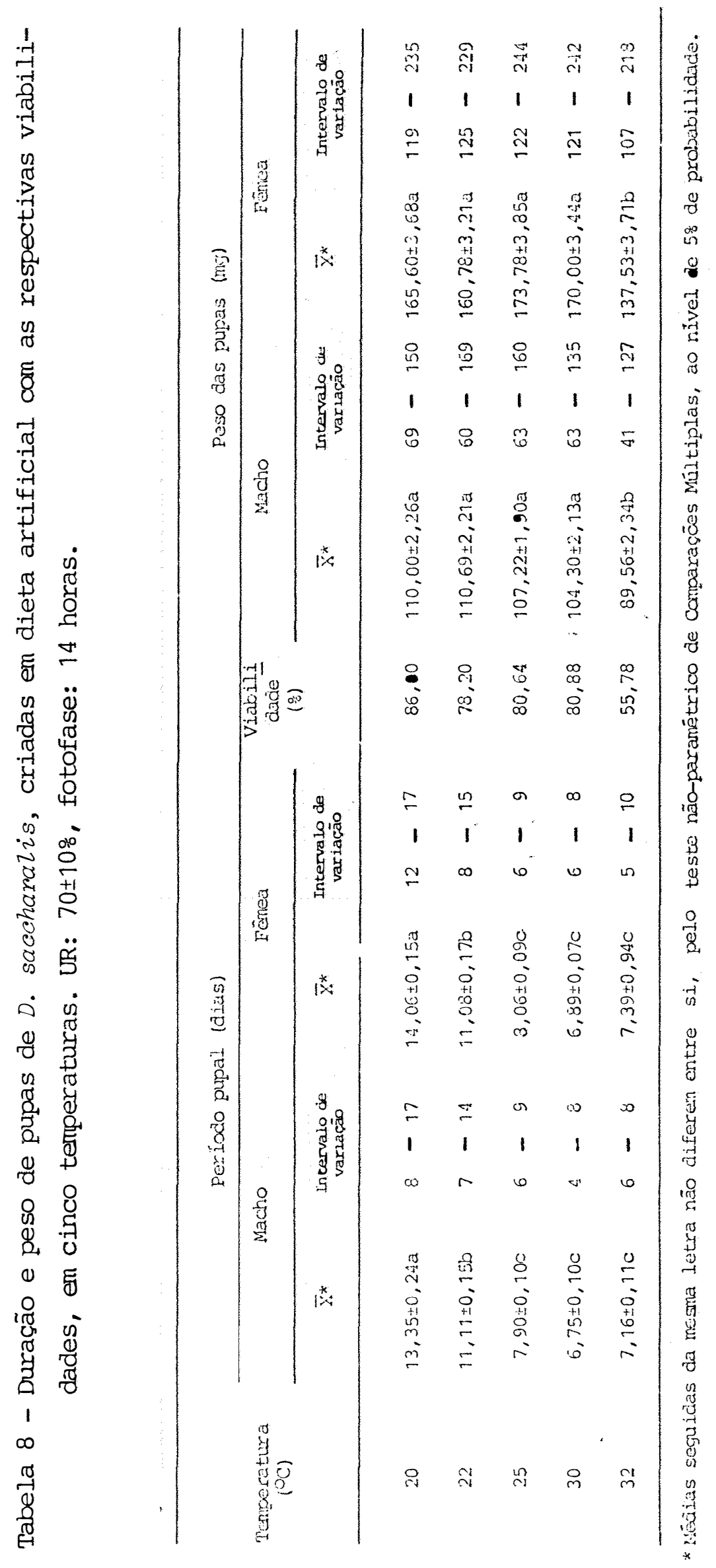




\subsubsection{RAZÃO SEXUAL}

Os dados referentes à razão sexual e relação sexual da broca-da-cana-de-açúcar, para cada temperatura, estão apresentados na Tabela 9. O maior número de machos foi registrado à $22^{\circ} \mathrm{C}$, sendo que a partir desta temperatura, houve uma diminuição desse número obtendo-se então uma proporção sexual ao redor de $10^{\circ}: 1 \%$.

Tabela 9 - Razão sexual e relação sexual de $D$. saccharalis*, criada em die ta artificial em cinco temperaturas. UR: 70 $10 \%$, fotofase: 14 ho ras.

Temperatura

$(\infty)$
Relação Sexual

$\left(0^{\circ}:\right.$ : $)$
Razão Sexual

$1,23: 1$

0,44

$1,31: 1$

0,43

$1,13: 1$

0,46

$1,12: 1$

0,47

30

$1,02: 1$

$-$

$\frac{0,49}{0,46}$

* A separação de sexos foi feita na fase de pupa.

Estes dados foram inferiores aos obtidos por FUCHS e HARDING (1978) e ARAÛJO et alii (1982) que verificaram em condições de campo 1,970:19 e 1,700:1\%, respectivamente, in dicando desta forma que, em condições naturais, o número de ma- 
chos é superior ao número de fêmeas. Entretanto, BERGAMIN (1948) constatou uma relação sexual de $1,110^{\circ}$ : 1 f e razão sexual de 0,47, embora o inseto fosse criado em colmos de cana-de-açúcar e não em dieta artificial, como no presente trabalho.

\subsection{FASE ADULTA}

\subsubsection{LONGEVIDADE E PERÍODO DE PRÉ-OVIPOSIÇÃO}

De modo geral, a longevidade de adultos foi decrescente com o incremento ténico até $25^{\circ} \mathrm{C}$, embora à $30{ }^{\circ} \mathrm{C}$, as fêmeas tenham apresentado longevidade semelhante àquelas submetidas à $25^{\circ} \mathrm{C}$ (Tabela 10). Em todas as temperaturas as fêmeas viveram mais que os machos, contrariando os dados obtidos por KING et alii (1975), os quais obtiveram dados bastante variáveis com relação à longevidade de adultos, sendo as fêmeas mais longevas à $22,26,28,32$ e $34{ }^{\circ} \mathrm{C}$ e os machos à $15,6,24$ e $30^{\circ} \mathrm{C}$.

As fêmeas viveram mais à $20{ }^{\circ} \mathrm{C}$, não havendo dife rença com relação à longevidade no intervalo de 25 a $30^{\circ} \mathrm{C}$. $\mathrm{Pa}-$ ra os machos, assim como ocorreu para as fêmeas, a maior longevidader foi obtida à $20^{\circ} \mathrm{C}$, embora não ocorresse diferença estatística com aqueles criados à $22^{\circ} \mathrm{C}$ (Tabela 10).

Não foi possivel a verificação da longevidade de adultos à $32^{\circ} \mathrm{C}$, pois, devido à baixa viabilidade pupal, foram obtidas poucas fêmeas nesta temperatura. 


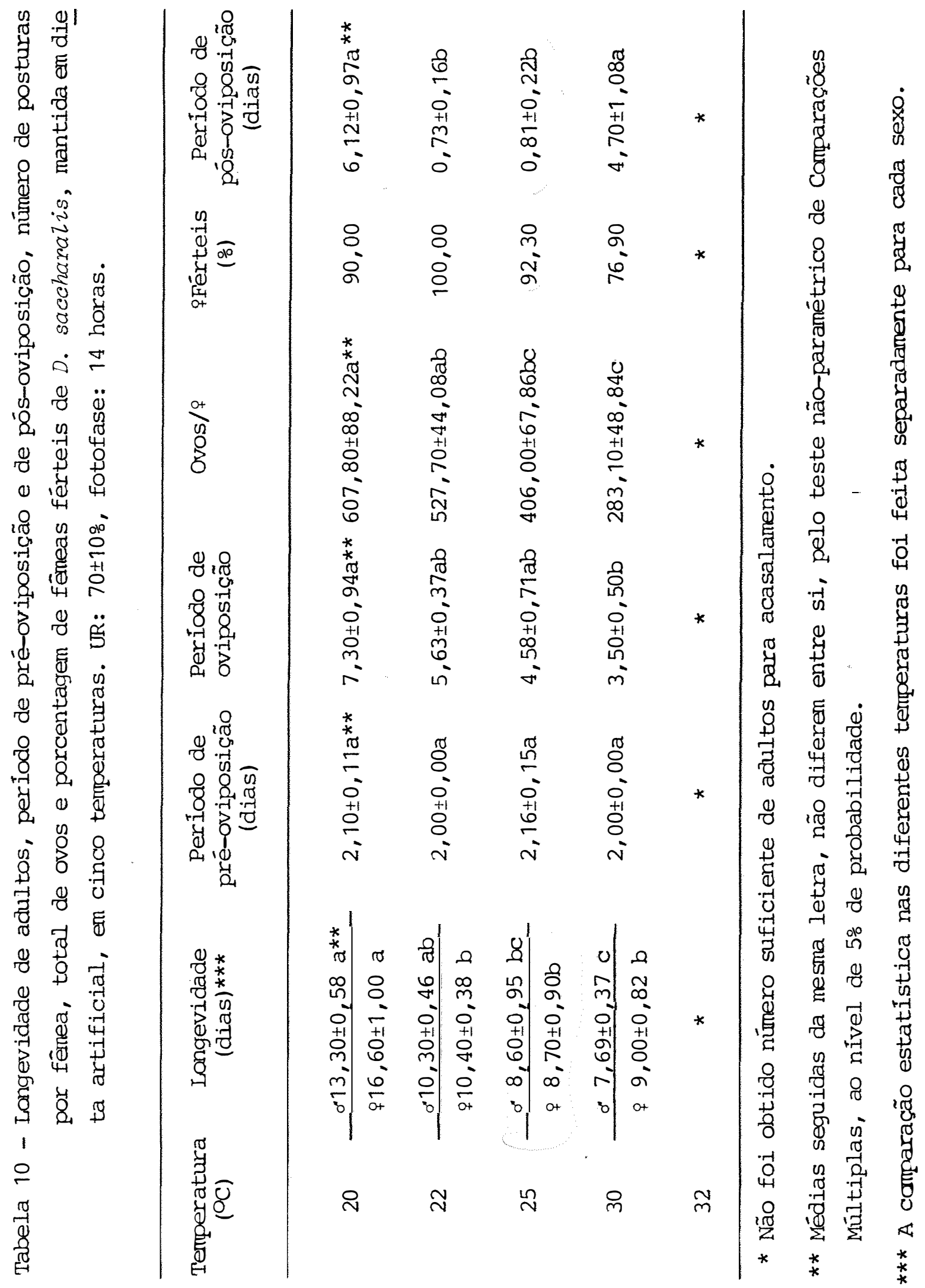


Os valores de longevidade de adultos obtidos por KING et alii (1975) foram inferiores, em todas as temperaturas estudadas, quando comparados aos da presente pesquisa, chegando a diferença em algumas vezes, como à $220 \mathrm{C}$, a ser de 5,5 dias em relação aos machos e 8,4 dias para fêmeas. Em vista do tipo de estudo realizado, torna-se difícil a explicação do porquê dessas diferenças, especialmente nas temperaturas mais baixas. Em temperaturas mais elevadas, a explicação poderia estar liga da a umidade no interior das gaiolas de acasalamento, pois em observações feitas no desenvolvimento do presente trabalho, ve rificou-se que as condições higrométricas do papel sulfite colocado nas gaiolas de criação são extremamente importantes na longevidade de adultos e na fertilidade de ovos. Em temperatü ras mais altas ocorreu o ressecamento mais rápido do papel que revestia internamente a gaiola, oferecendo condições adversas ao inseto ali confinado. Utilizando-se pares termoelétricos, pôde-se verificar que em gaiolas nas quais se "molhava" o papel sulfite (condição normal de criação), a umidade atingiu 92\%, enquanto em gaiolas onde não ocorreu esta prática, a umidade chegou a 70\%, independente da temperatura. Como os autores anteriormente citados não fizeram referência às condições de umi dade de gaiolas, as variações deste parâmetro, em função da tem peratura, podem ter levado a estes resultados discrepantes.

A porcentagem de adultos deformados foi maior na temperatura de $32^{\circ} \mathrm{C}$ (Tabela 11). Este fato pode ser explicado pelos resultados obtidos por GRAU e TERRIERE (1967) com Iricho 
plusia ni (Hübner, 1802) onde temperaturas elevadas afetaram a disponibilidade de ácidos graxos na fase pupal, provocando deformações nas asas deste lepidóptero. O aumento da porcentagem de deformações de asas em função da temperatura, também foi ob servado em Autographa californica (Speyer, 1815) e Peridroma saucia (Hubner) por SCHAFER et alii (1968).

Tabela 11 - porcentagem de deformação de ađultos de D. saccharalis, provenientes de lagartas criadas em dieta artificial em cinco temperaturas. UR: $70 \pm 10 \%$, fotofase: 14 horas.

Temperatura $\left({ }^{\circ}\right)$

Deformação de adultos

(\%)

20

22

25

30

32
3,00

4,54

2,00

11,00

30,20

O período de pré-oviposição não diferiu estatis ticamente nas diferentes temperaturas, indicando que a tempera tura não exerceu nenhuma influência sobre este parāmetro bioló gico (Tabela 10). Esses dados coincidem com as observações de KING et alii (1975) que encontraram uma média de 2 dias para este período. 


\subsubsection{PERÍODO DE OVIPOSIÇÃO E CAPACIDADE DE POSTURA}

O número de posturas foi decrescente com o aumento da temperatura (Tabela 10), não havendo diferença estatística no intervalo de 20 a $25^{\circ} \mathrm{C}$. A diminuição do período de oviposição em função da elevação da temperatura foi observado em Alabama argilzacea (Hübner, 1818) por KASTEN (1980) e, em S. frugiperda por FERRAZ (1982).

Considerando-se a porcentagem de fêmeas que ovipositaram, observou-se que apenas à $22^{\circ} \mathrm{C}$ todas as fêmeas efe tuaram postura, havendo portanto efeito da temperatura na porcentagem de fêmeas férteis (Tabela 10) e interação entre tempe ratura e idade das fêmeas (Figura 2). Embora à $200^{\circ}$, apenas 90\% tivessem sido férteis verificou-se que o total de ovos por fêmea foi superior quando comparado à 25 e $300 \mathrm{C}$ :

Pôde-se observar que a temperatura de $200^{\circ} \mathrm{C}$ foi ideal para postura de D. saccharalis, embora o total de ovos por fêmea não apresentasse diferença estatística em relação à $22^{\circ} \mathrm{C}$ (Tabela 10). Estes resultados coincidem com ARAÚJO et alii (1980), que observaram que nas temperaturas de 20 e $23^{\circ} \mathrm{C}$ as fêmeas apresentaram maior capacidade de postura, embora os valores encontrados tenham sido inferiores aos obtidos no pre sente trabalho, ou seja, 448,48 e 324,70 ovos, respectivamen- 


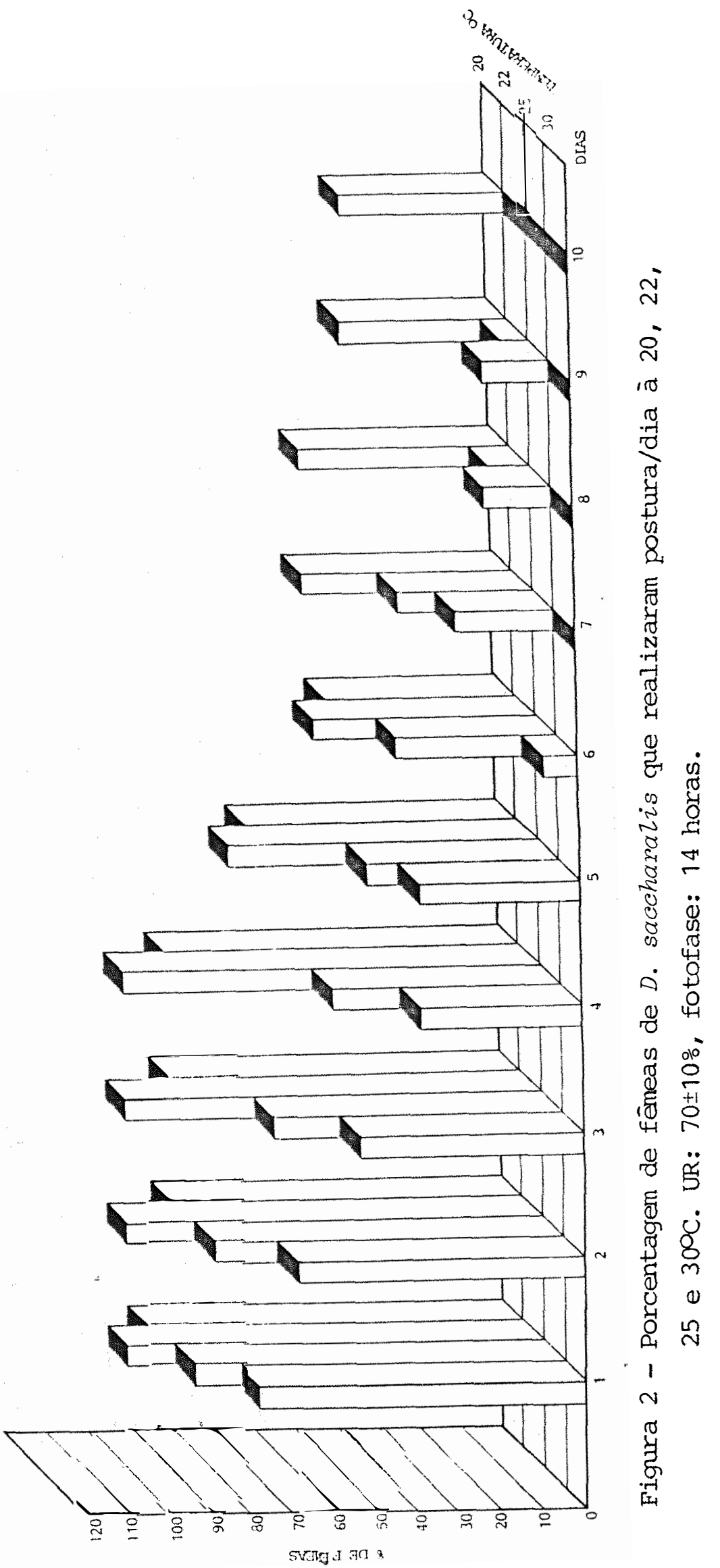


te. Por outro lado, KING et alii (1975) obtiveram maior número de ovos quando os adultos foram criados à 24 e $26^{\circ} \mathrm{C}$, sendo 0 número médio de ovos por fêmea 729 e 435, respectivamente. Os baixos valores obtidos por ARAÚJO et alii (1980) podem ser atribuidos ao elevado número de indivíduos na gaiola de criação, pois o tamanho do recipiente de criáção pode também influenciar na fecundidade e no comportamento dos insetos (PETERS e BARBOSA, 1977), fato observado por SGRILLO (1973) para D. saccharalis. A discordância existente entre os resultados do presente trabalho, com aqueles de KING et alii (1975) pode ser atribuida à diferença de "strains", ou talvez a diferente proporção de machos e fêmeas utilizada nas duas pesquisas, para estudo da fase adulta. Por este motivo, sugere-se a realiza ção de estudos para se determinar a melhor relação entre machos e fêmeas, uma vez que a literatura é bastante divergente neste aspecto. Assim, MISKIMEN (1965) encontrou a melhor proporção entre machos e fêmeas como sendo 2:1, SGRILLO (1973) e GUEVARA (1976) 3:1 e KING et alii (1975) 1:1.

De um modo geral, a maior porcentagem de postura ocorreu nos 4 primeiros dias (Figuras 2 e 3 ), coincidindo com os resultados de WALKER e FIGUEROA (1964) que obtiveram 76,58\% dos ovos de $D$. saccharalis do primeiro ao quarto dia de postura. Entretanto, ALVAREZ (1970) e SGRILLO (1973) constataram à $26^{\circ} \mathrm{C}$, uma porcentagem média de postura neste mesmo período de $85,52 \%$ e $98,94 \%$, respectivamente, o que pode indicar que, nesta temperatura,o periodo de postura se concentrou num período de 
tempo menor. Na presente pesquisa, a partir do quarto dia houve uma diminuição da postura, nas diferentes temperaturas, indicando que a fecundidade média diária das fêmeas diminui com a longevidade.

A $20^{\circ} \mathrm{C}$ e $30^{\circ} \mathrm{C}$ as fêmeas apresentaram um periodo médio de pós-oviposição de 6,1 e 4,7 dias (Tabela 10), respectivamente, sendo que à 22 e $25^{\circ} \mathrm{C}$ 95\% morreram após a última postura.

De uma maneira geral, a viabilidade foi maior nas cinco primeiras posturas, entretanto, à $20^{\circ} \mathrm{C}$ houve um aumento na sexta, sétima e oitava posturas (Figura 3).

A $300^{\circ}$ a viabilidade dos ovos foi inferior à 60\% em todas posturas, mostrando assim, que a temperatura afetou o comportamento reprodutivo dos adultos. MISKIMEN observou que elevadas temperaturas afetam a maturação dos ovos e a fertilidade de fêmeas de $D$. saccharalis. Por outro lado, esta baixa viabilidade talvez possa ser explicada pelos resultados obtidos por JASIC (1967a), o qual verificou que fêmeas mantidas à $60 \%$ de umidade depositaram ovos cuja viabilidade atingiu $36,3 \%$; na presente condição experimental $\left(30^{\circ} \mathrm{C}\right)$, a umidade da gaiola de criação pode ter diminuído em função do rápi do ressecamento do papel que revestiu suas paredes internas, afe tando assim a porcentagem de eclosão.

As viabilidades obtidas no presente trabalho $45,80 \%\left(30^{\circ} \mathrm{C}\right), 72,60 \%\left(25^{\circ} \mathrm{C}\right), 82,60\left(22^{\circ} \mathrm{C}\right)$ e $73,40 \%\left(200^{\circ} \mathrm{C}\right)$ foram inferiores àquelas obtidas por ARAÚJO et alii (1980) na faixa de 17 a $32^{\circ} \mathrm{C}$. 


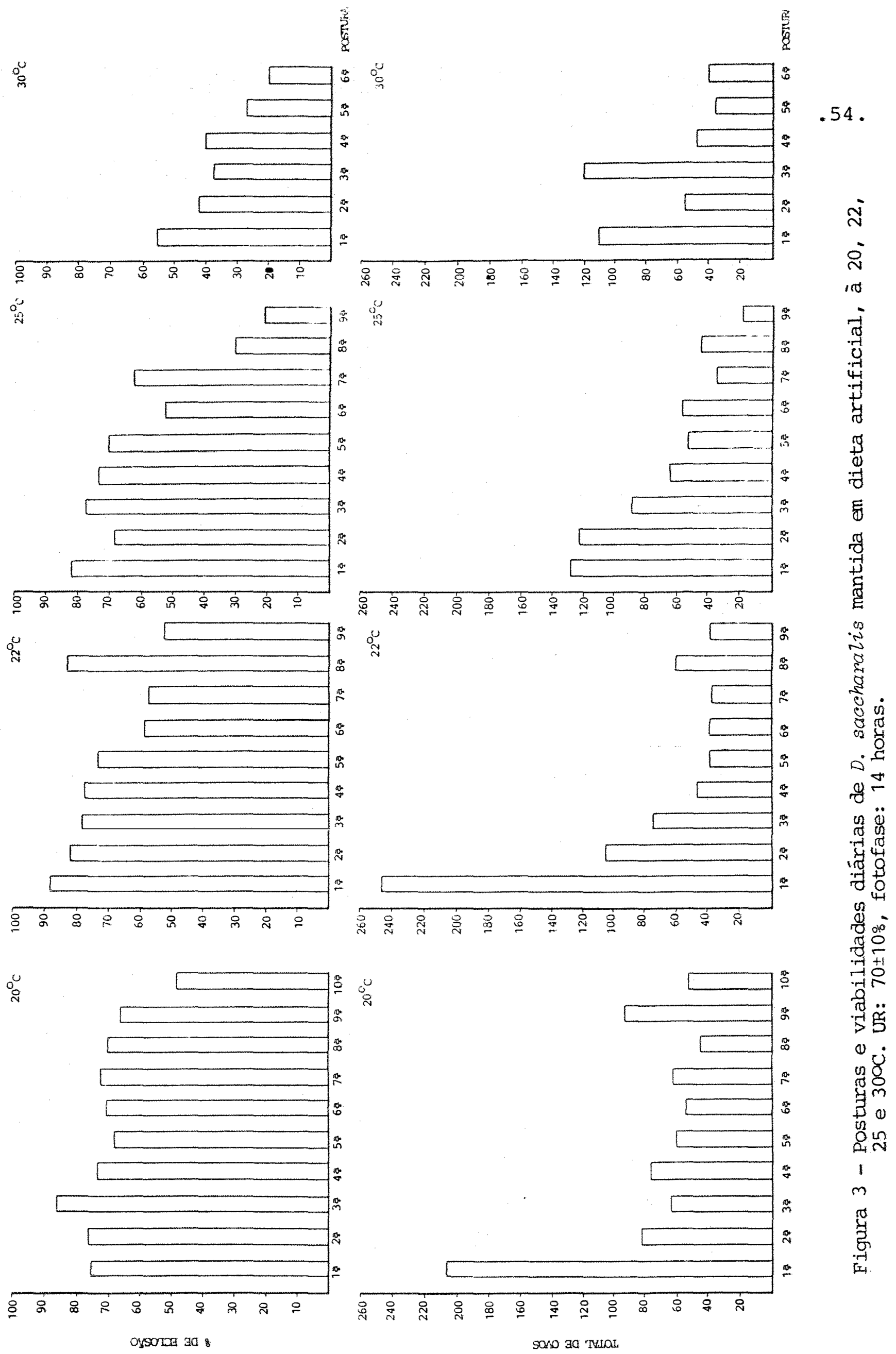




\subsection{Ciclo tOTAL}

O ciclo biológico completo lovo até morte de adultos) de $D$. saccharalis consta na Tabela 12 e Figura 4.

Como as diferentes fases do ciclo biológico de D. saccharalis foram influenciadas pela temperatura, é evidente que o ciclo total também o foi, havendo uma diminuição com a elevação térmica nas condições experimentais estudadas. Pôde-se observar que a temperatura de $32^{\circ} \mathrm{C}$ foi prejudicial ao in seto, uma vez que nessa condição obteve-se uma viabilidade total de 33,2\% (Tabela 13). Houve um alongamento do ciclo à 200C, ocorrendo uma diminuição de $26,45,35,09,41,56$ e 55,60 dias nas temperaturas de $22,25,30$ e $32^{\circ} \mathrm{C}$, respectivamente, comparada à quela temperatura (Tabela 12). Tal tendência foi também observada por KING et alii (1975), muito embora estes autores tenham observa do uma duração de 63,45 e 35,05 dias do ciclo de vida do inseto mantido à 22 e $30^{\circ} \mathrm{C}$, resoectivamente. 


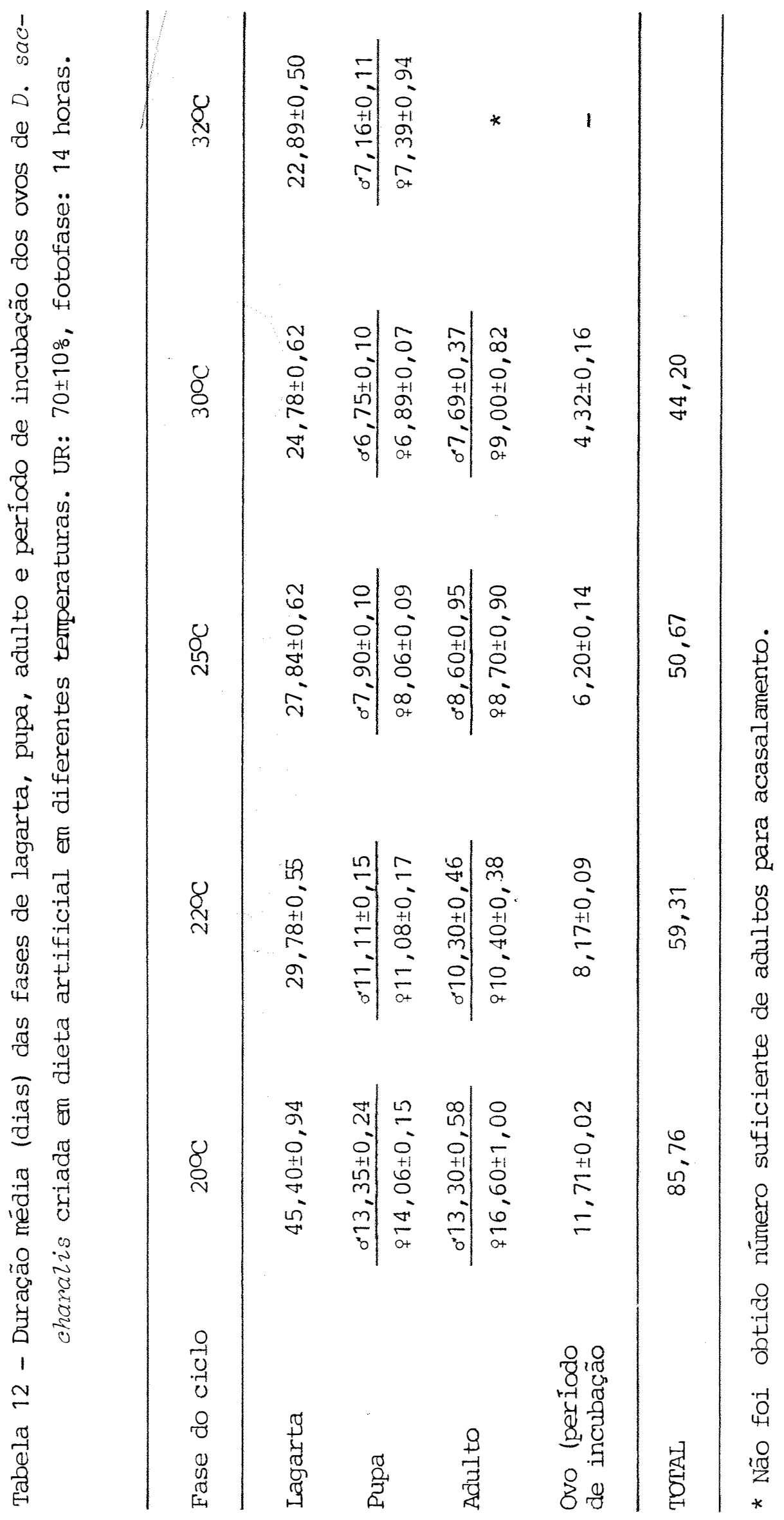




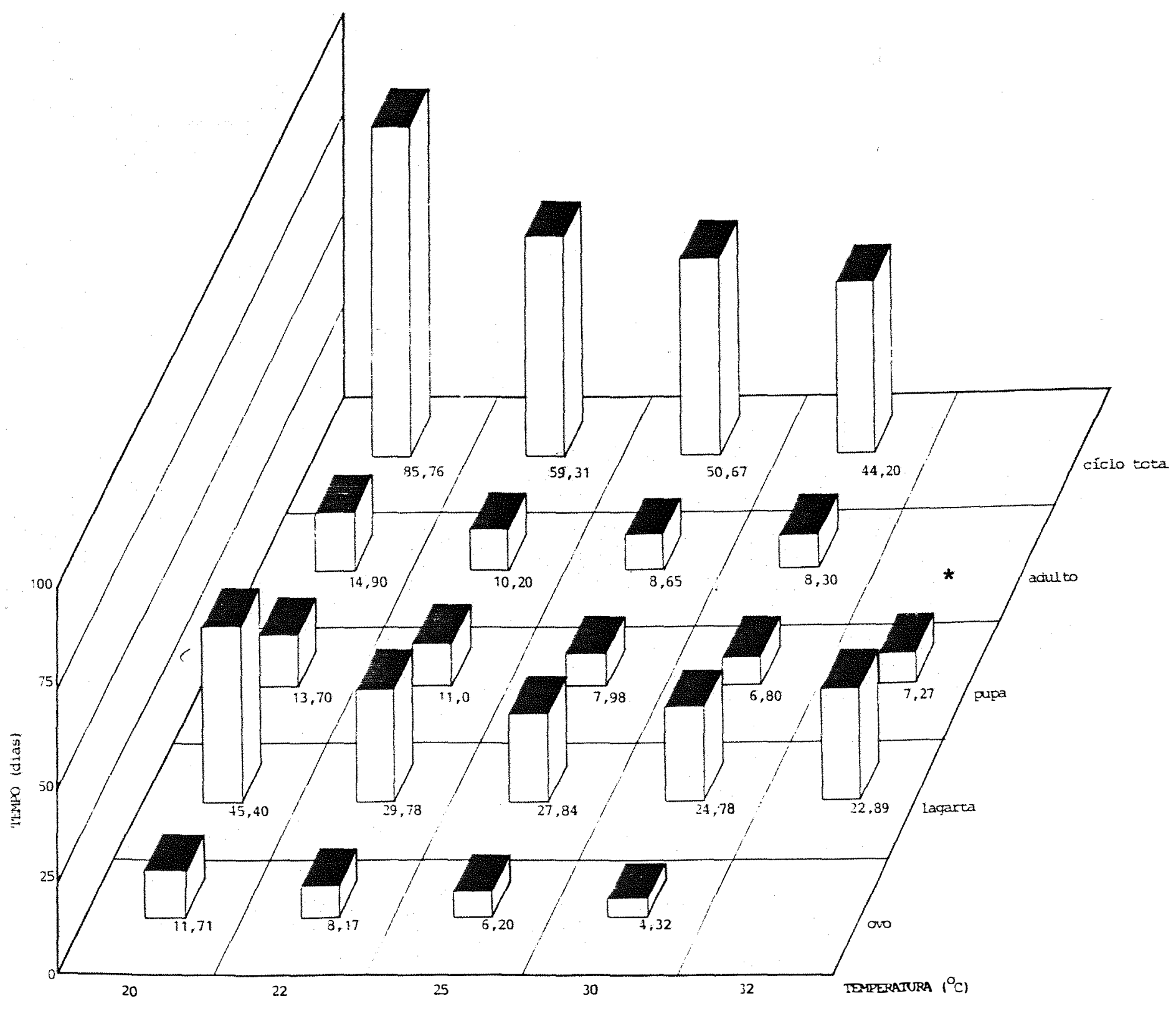

Figura 4 - Duração média (dias) das fases de ovo, lagarta, pupa e adulto e ciclo total de $D$. saccharalis, criada en dieta artificial em di ferentes temperaturas. UR: $70 \pm 10 \%$, fotofase: 14 horas.

* Não foi obtido número suficiente de adultos para acasalamento. 
Tabela 13 - Viabilidade total do ciclo de D. saccharalis criada en dieta

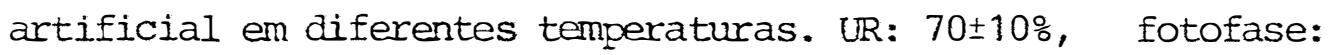
14 horas.

$\begin{array}{ll}20 & 61,25 \\ 22 & 55,00 \\ 25 & 61,90 \\ 30 & 68,20 \\ 32 & 33,20\end{array}$

\subsection{TABELA DE VIDA DE FERTILIDADE}

As tabelas de vida de D. saccharalis à 20, 22, 25 e 300C, são apresentados nas Tabelas 14, 15, 16 e 17. Como não se obteve nümero de acultos suficiente para acasalamento à $32^{\circ} \mathrm{C}$, não foi possivel a elaboração de tabelas de vida de fertilidade nesta temperatura.

Observou-se que a taxa liquida de aumento $\left(\mathrm{R}_{0}\right)$ foi decrescente com o aumento da temperatura, sendo maior à 200C, com uma capacidade de aumento de 161,53 vezes, de uma geração para outra. 
decresceu com a elevação térmica, tendo menor valor à $30^{\circ} \mathrm{C}$. En tretanto, a razão finita de aumento $(\lambda)$ foi maior à $30^{\circ} \mathrm{C}$, sendo que à $200 \mathrm{C}$ atingiu menor valor.

Embora à $20^{\circ} \mathrm{C}$, o inseto tenha apresentado maior capacidade de postura e de aumento de uma geração para outra $\left(\mathrm{R}_{\mathrm{O}}=161,53\right), \mathrm{a} 30^{\circ} \mathrm{C}$, a capacidade de produzir fêmeas que darão fèmeas foi maior $(\lambda=1,0880)$ e a duração média de umą geração foi inferior em 48,05 dias em relação àquela temperatu$\mathrm{ra}$, indicando que nestas condições $\left(30^{\circ} \mathrm{C}\right)$ é possivel obter - se um maior número de gerações da praga durante um ano.

Como os indices $\left(R_{O}, T, r_{m}\right.$ e $\left.\lambda\right)$ foram obtidos em condições de laboratório os valores apresentados não são definitivos, uma vez que a população de D. saccharalis, em condi ções de campo, é atacada por inúmeros parasitos e predadores (DEGASPARI et alii, 1981; DEGASPARI et alii, 1983a); sofre influência dos fatores climáticos e tem sua população regulada por determinados tratos culturais, como a queima (DEGASPARI et alii, 1983b). Desta forma, são necessários estudos em condições naturais, para elaboração de tabelas de vida ecológicas, as quais são de grande valia para compreensão da dinâmica popu lacional da praga. 
Tabela 14 - Tabela de vida de fertilidade para $D$. saccharalis mantida em dieta artificial, à temperatura de $200 \mathrm{C}$. UR: $70 \pm 10 \%$, fotofase: 14 horas.

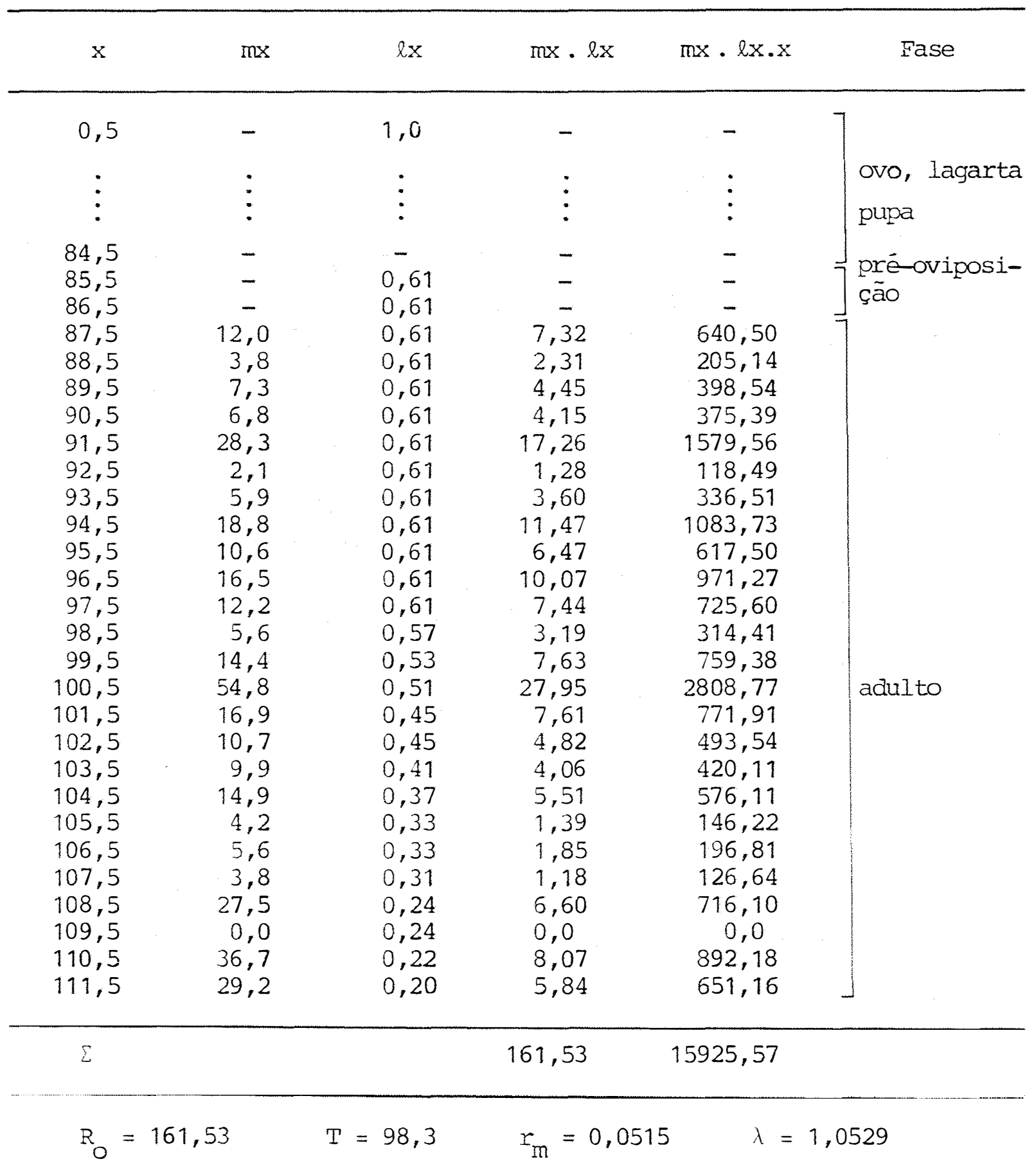


Tabela 15 - Tabela de vida de fertilidade para $D$. saccharalis mantida em dieta artificial à temperatura de $220 \mathrm{C}$. UR: $70 \pm 10 \%$, fotofase: 14 horas.

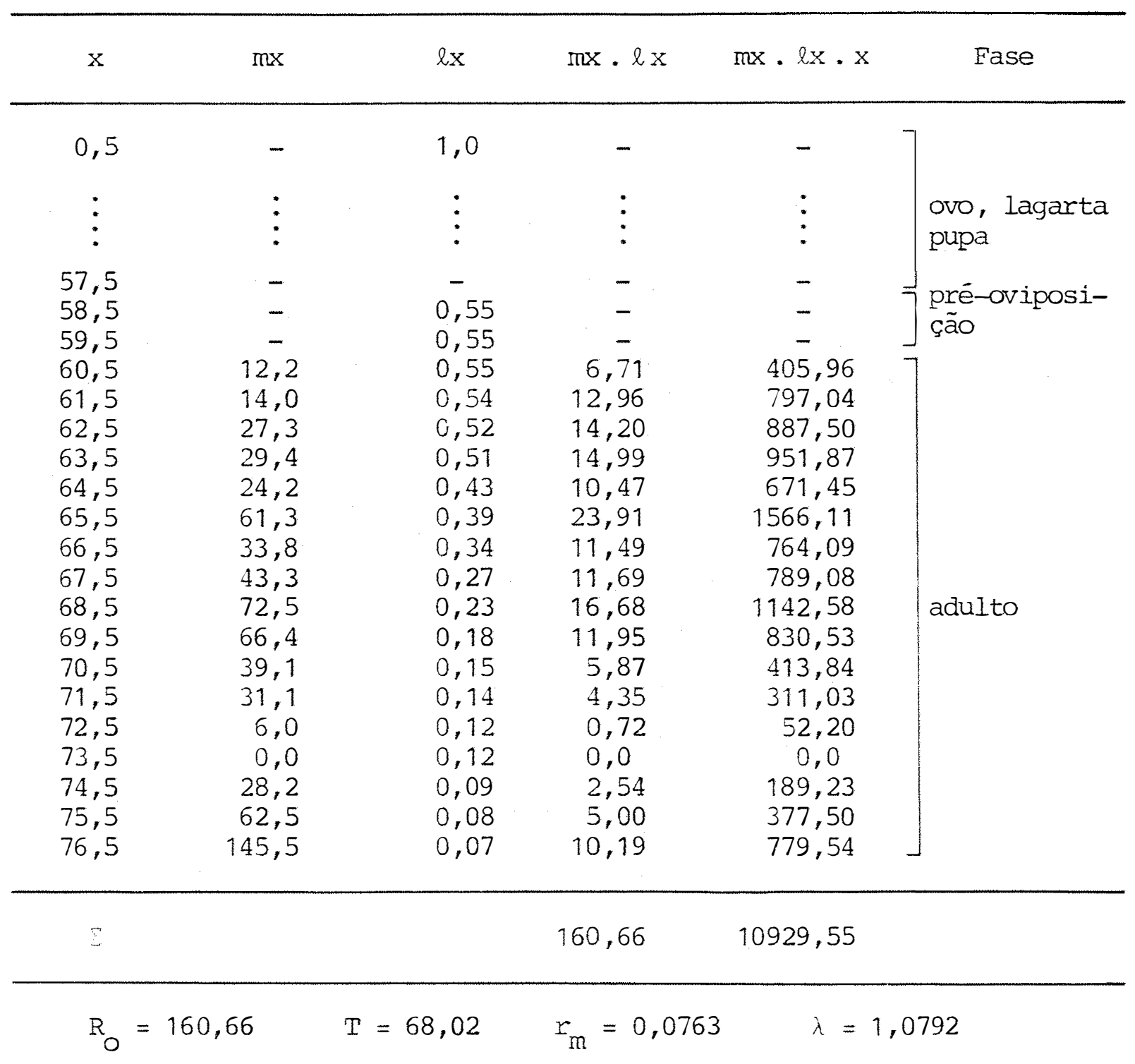


Tabela 16 - Tabela de vida cie fertilidade para D. saccharalis mantida en dieta artificial, à temperatura de 250 C. UR: $70 \pm 10 \%$, fotofase: 14 horas.

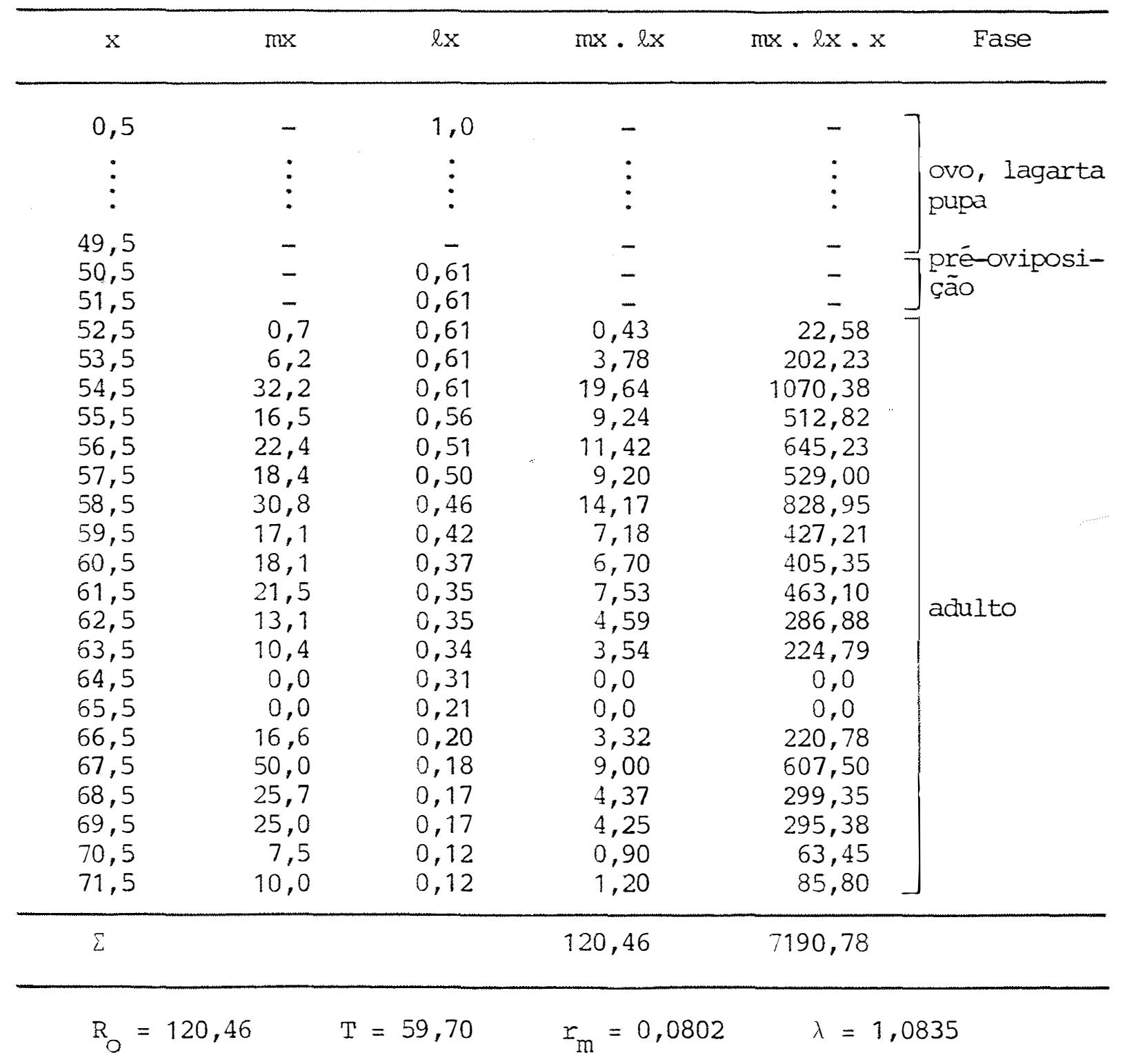


Tabela 17 - Tabela de vida de fertilidade para D. saccharalis mantida em dieta artificial, à temperatura de $30{ }^{\circ} \mathrm{C}$. UR: $70 \pm 10 \%$, fotofase: 14 horas.

\begin{tabular}{|c|c|c|c|c|c|}
\hline $\mathrm{x}$ & $m x$ & $2 x$ & $m x \cdot l x$ & $m x \cdot l x \cdot x$ & Fase \\
\hline 0,5 & - & 1,0 & - & - & \\
\hline$\vdots$ & $\vdots$ & $\vdots$ & $\vdots$ & $\vdots$ & $\begin{array}{l}\text { ovo, lagarta } \\
\text { pupa }\end{array}$ \\
\hline $\begin{array}{l}42,5 \\
43,5 \\
44,5 \\
45,5 \\
46,5 \\
47,5 \\
48,5 \\
49,5 \\
50,5 \\
51,5 \\
52,5 \\
53,5 \\
54,5 \\
55,5 \\
56,5 \\
57,5 \\
58,5 \\
59,5 \\
60,5\end{array}$ & $\begin{array}{r}- \\
- \\
- \\
2,4 \\
1,3 \\
18,5 \\
31,5 \\
8,8 \\
6,5 \\
0,0 \\
36,3 \\
5,8 \\
0,0 \\
0,0 \\
2,3 \\
5,7 \\
6,1 \\
4,9 \\
2,6\end{array}$ & $\begin{array}{l}-\overline{6} \\
0,68 \\
0,68 \\
0,68 \\
0,68 \\
0,68 \\
0,68 \\
0,66 \\
0,59 \\
0,55 \\
0,47 \\
0,33 \\
0,31 \\
0,29 \\
0,26 \\
0,20 \\
0,20 \\
0,20 \\
0,20\end{array}$ & $\begin{array}{c}- \\
- \\
- \\
1,63 \\
0,88 \\
12,58 \\
21,42 \\
5,81 \\
3,84 \\
0,0 \\
17,06 \\
1,91 \\
0,0 \\
0,0 \\
0,60 \\
1,14 \\
1,31 \\
0,98 \\
0,52\end{array}$ & $\begin{array}{c}- \\
- \\
- \\
74,17 \\
40,92 \\
597,55 \\
1038,87 \\
287,60 \\
193,92 \\
0,0 \\
895,65 \\
102,19 \\
0,0 \\
0,0 \\
33,90 \\
65,55 \\
77,22 \\
58,31 \\
31,46\end{array}$ & $\begin{array}{l}\text { prée-oviposi- } \\
\text { ção }\end{array}$ \\
\hline$\Sigma$ & & & 69,59 & 3497,31 & \\
\hline
\end{tabular}




\subsection{Consideracões gerais}

No Brasil, o controle da broca-da-cana é feito através da criação e liberação de vārios parasitóides do inseto, destacando-se entre estes o microhimenóptero Apantelés fla vipes (Cameron, 1891) e os taquinídeos Metagonistylum minense (Towns., 1926) e Paratheresia claripalpis (Wulf, 1896). Assim, para produção massal desses inimigos naturais, é necessária a criação em grande escala do hosoedeiro sobre o qual criam - se os parasitóides.

Desta forma, os laboratórios de multiplicação des ses inimigos naturais necessitam dispor de técnicas eficientes e aprimoradas para garantirem elevados indices de multiplicação dos parasitóides (MENDES et alii, 1977) .

Atualmente, as tēcnicas de criação massal do hos pedeiro (D. saccharalis), visando a produção em alta escala de seus parasitóides, são bastante conhecidas (MENDES, 1980; TERAN, 1980; MACEDO et alii, 1983). Entretanto, é necessário um constante aprimoramento nessas técnicas de criação visto que alguns ajustes ou adaptações no sistema de produção podem trazer sensiveis beneficios tanto para obtenção de um maior número de insetos num menor período de tempo como também na redução de custos operacionais. Assim, é de fundamental importância o desenvolvimento äe técnicas que possibilitem economia na criação, permitindo a obtenção de um maior número de insetos possível, compatível com a infra-estrutura dos laboratórios de 
criação e com a mão-de-obra disponivel.

Através dos resultados obtidos no presente trabalho, pōde-se constatar que as condições de temperatura do la boratório são extremamente importantes para a criação massal de D. saccharalis, em relação às diferentes fases do seu ciclo bio lógico.

Portanto, em laboratório, que apresente controle de temperatura, pode-se manter os ovos, lagartas e pupas em temperatura de 300C. Nesta temperatura obteve-se menor duração e/ou alta viabilidade (Tabelas 1, 2 e 8).

$\overline{\mathrm{A}} 300^{\circ} \mathrm{C}$, as lagartas atingiram o 49 e 59 Instares em 14,49 e 17,19 dias, respectivamente, com viabilidades de 95,47 e 94,80\% (Tabela 6); período no qual, segundo MACEDOetalii. (1983), as lagartas estão aptas a servirem de hospedeiro dos parasitói des.

As equações loqísticas apresentadas nas Tabelas 18 e 19 e Figuras 5 e 6 são de suma importāncia em programas de criação massal, para estimar a porcentagem de obtenção de pupas ou adultos (PARRA et alii, 1983). Através do $\mathrm{T}_{50}$ (Tabela 18) pode-se observar que embora o tempo necessário para transforma ção da população de lagartas em pupas à $300 \mathrm{C}$ fosse superior em 2,73 dias, em relação à 320 C, a viabilidade nesta temperatura (300C) foi bastante superior (Tabela 2).

Com relação à fase pupal, o peso das pupas em ambos os sexos mantidos à 300C, não mostrou diferença estatística em relação à 20,22 e $25^{\circ} \mathrm{C}$. O peso de pupas fêmeas, que é 
de grande importāncia num programa de criação (pois as mais pe sadas serão as mais fecundas), foi maior à $25^{\circ} \mathrm{C}$, embora não dife-risse de $30^{\circ} \mathrm{C}$ (Tabela 8). Através da Tabela 19, pôde-se constatar a redução do período pupal em temperatura de $30^{\circ} \mathrm{C}$, com uma viabili dade de $80,88 \%$ (Tabela 8 ).

Por outro lado, para criação de adultos deve-se optar pela temperatura de $200 \mathrm{C}$ pois, nesta condição obtém - se maior número de ovos por fémea (embora não diferindo de $22^{\circ} \mathrm{C}$ ), maior período de oviposição e maior longevidade, tanto para os machos como para as fémeas (Tabela 10). Pelos resultados obtidos conclui-se que em grandes criações, os adultos devem ser mantidos até o 5 o dia de postura, pois neste período as fêmeas colocam $80 \%$ dos ovos (Figura 3). A partir deste período, o nümero de ovos por postura diminui, sendo que do 69 dia de postu ra em diante apenas 50\% das fêmeas ovipositam (Figura 2), produzindo um baixo nümero de ovos e com menor viabilidade (Figura 3). Desta forma, a eliminação dos adultos após o 5o dia é justificável, pois num programa de criação massal, a obtenção de ovos viáveis e em grande quantidade é um dos pontos mais importantes do processo. 
Tabela 18 - Equações logísticas* representativas da \% de abtenção de pupas x dias de desenvolvimento, para $D$. saccharalis submetida a diferentes temperaturas, com as respectivas $T_{50}$ UR: $70 \pm 10 \%$, fotofase: 14 horas.

\begin{tabular}{|c|c|c|c|c|c|}
\hline \multirow{2}{*}{$\begin{array}{c}\text { Temperatura } \\
\left({ }^{\circ} \mathrm{C}\right)\end{array}$} & \multicolumn{4}{|c|}{ Coeficientes } & \multirow{2}{*}{$\frac{\mathrm{T}_{50}}{(\text { dias }) * *}$} \\
\hline & a & $\mathrm{b}$ & $r$ & $r^{2}$ & \\
\hline 20 & 5,59 & $-0,72$ & $-0,98$ & 0,97 & 43,43 \\
\hline 22 & 4,66 & $-0,16$ & $-0,94$ & 0,89 & 27,84 \\
\hline 25 & 5,65 & $-0,20$ & $-0,90$ & 0,81 & 28,10 \\
\hline 30 & 5,96 & $-0,23$ & $-0,93$ & 0,87 & 25,38 \\
\hline 32 & 6,25 & $-0,2 i$ & $-0,92$ & 0,85 & 22,65 \\
\hline
\end{tabular}

* Equação geral: $y=\frac{1}{1+e^{a+b x}}$

$y=\frac{\circ}{d e}$ obtenção;

$x=$ duração de desenvolvimento (dias);

$\underline{a}$ e $\underline{b}=$ coeficientes.

** Tempo necessário (dias) para transformação de 50\% da população. 
Tabela 19 - Equações logísticas* representativas da \% de obtenção de adultos $\mathrm{x}$ dias de desenvolvimento, para $D$. saccharalis submetida a diferentes temperaturas com os respectivos $T_{50} \cdot U R: 70 \pm 10 \%$, fotofase: 14 horas.

\begin{tabular}{|c|c|c|c|c|c|}
\hline \multirow{2}{*}{$\begin{array}{l}\text { Temperatura } \\
(\text { (O) }\end{array}$} & \multicolumn{4}{|c|}{ Coeficientes } & \multirow{2}{*}{$\begin{array}{c}\mathrm{T}_{50} \\
\text { (dias) ** }\end{array}$} \\
\hline & $\mathrm{a}$ & $\mathrm{b}$ & $r$ & $r^{2}$ & \\
\hline 20 & 13,56 & $-1,04$ & $-0,99$ & 0,98 & 13,02 \\
\hline 22 & 13,41 & $-1,25$ & $-0,99$ & 0,98 & 10,70 \\
\hline 25 & 18,86 & $-2,56$ & $-0,98$ & 0,97 & 7,35 \\
\hline 30 & 14,85 & $-2,39$ & $-0,99$ & 0,98 & 6,20 \\
\hline 32 & 12,50 & $-1,81$ & $-0,96$ & 0,92 & 6,89 \\
\hline
\end{tabular}

* Equação geral: $y=\frac{1}{1+e^{a+b x}}$

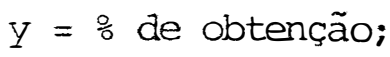

$x=$ duração de desenvolvimento (dias);

$\underline{\mathrm{a}} \mathrm{e} \underline{\mathrm{b}}=$ coeficientes.

** Tempo necessário (dias) para transformação de 50\% da população. 

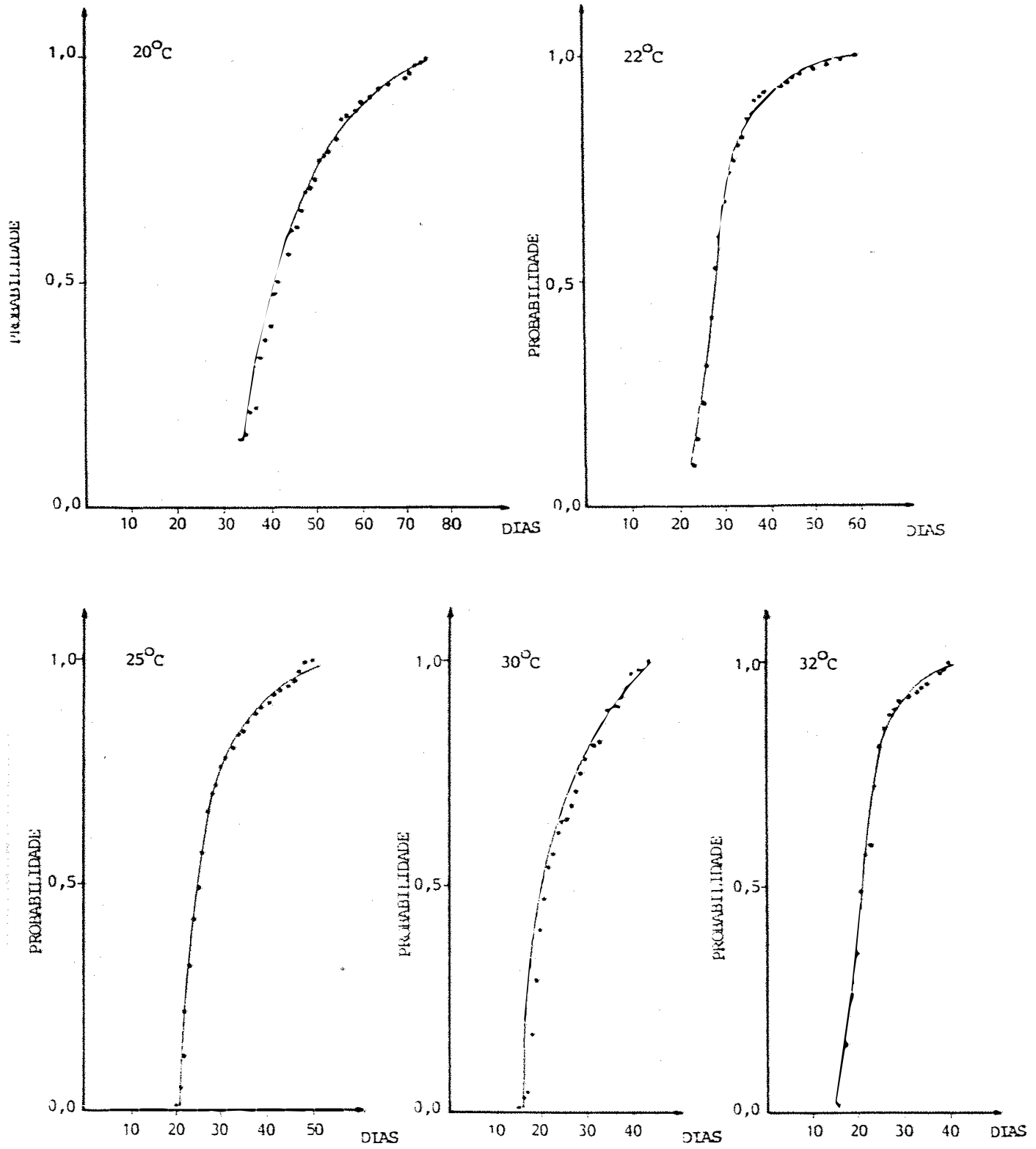

Figura 5 - Probabilidade de obtenção de pupas de $D$. saccharalis en diferen tes temperaturas. UR: $70 \pm 10 \%$, fotofase: 14 horas. 

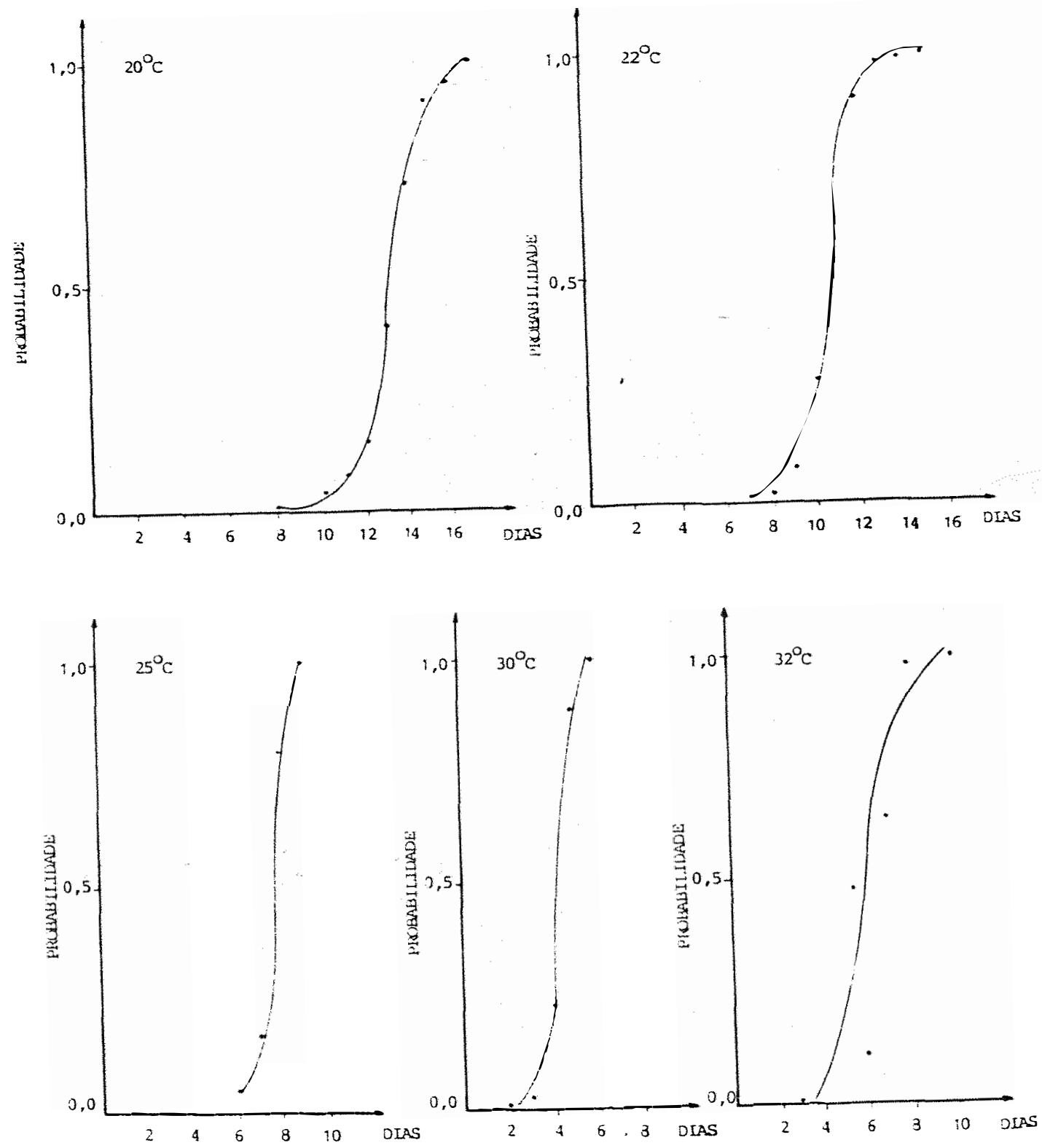

Figura 6 - Probabilidade de obtenção de adultos de $D$. saccharalis en diferentes termeraturas. UR: $70 \pm 10 \%$, fotofase: 14 horas. 


\subsection{Determinação DAS EXIGÊNCIAS téRMiCAS}

Os limiares de desenvolvimento obtidos para as fases de ovo, lagarta, pupa e adulto e ciclo total são apresen tados na Tabela 20. Os resultados obtidos são inferiores aos de JASIC (1967b), que encontrou valores de 12,$8 ; 12,1 ; 12,6$ e $12,5^{\circ} \mathrm{C}$, respectivamente como temperaturas bases para as fases de ovo, lagarta, pupa e ciclo total. A temperatura base do ciclo total obtida na presente pesquisa $\left(9,4^{\circ} \mathrm{C}\right)$ foi inferior àquela registrada por JASIC $(1967 \mathrm{~b})\left(12,5^{\circ} \mathrm{C}\right)$. As diferenças observadas podem ser devidas ao fato daquele autor ter criado $D$. saccharalis em meio natural, ou seja, em colmos de milho, além, evidentemente de se tratarem de "strains" diferentes.

A constante térmica para o ciclo total do inseto foi de 882,53 GD. Computando-se apenas as fases de ovo, lagarta e pupa, o valor da constante térmica foi de 710,51 GD (Ta bela 20), bastante próximo aos 714,6 GD obtidos por JASIC (1967b), que considerou apenas estas três fases para tal deter minação. A diferença de 4,19 GD pode ser considerada desprezivel para elaboração de modelos de previsão de pragas. 
Tabela 20 - Temperaturas bases (Tb) e constantes térmicas (k) das diferentes fases do ciclo biológico de $D$. saccharalis criada en dieta artificial.

Fases do ciclo

To $(\infty)$ *

k (GD)

Ovo

11,2

67,47

Iagarta

7,3

516,96

Pupa

10,6

126,08

Adulto

7,1

172,02

Ciclo total

9,4

882,53

* Calculada pelo método do coeficiente de variação.

4.9. ESTIMATIVA DE NÚMERO DE GERAÇ̃̃es ANUAIS DE D. saccharaZis

O número de gerações de D. saccharalis, tomando-se por base suas exigências térmicas, nas localidades canavieiras selecionadas, consta na Figura 7. e as temperaturas médias diárias e mensal do ar desses locais, nos Apéndices 1,2,3 e 4. Em todas as localidades o inseto apresentou 5 gerações anuais, concordando com BERGAMIN (1948), BEFGAMTN (1949), GALLO (1964) e GALLO et alii (1978), os quais relataram que nas 
condições do Estado de São Paulo, a praga pode apresentar de 4 a 5 gerações durante o ano. Entretanto, estes dados não concor dam com os resultados obtiaos por WALDER (1976), o qual concluiu que D. saccharalis apresenta 4 gerações nas regiões de Ribeirão Preto, Araraquara, Jaú e Piracicaba, baseado em levan tamento de formas imaturas (lagartas e pupas).

Nas 4 localidades, a última geração (a partir de abril) apresentou maior duração (Figura 7). Em condições naturais, as temperaturas médias diārias a partir de abril são inferiores à $23^{\circ} \mathrm{C}$ nas 4 localidades (Apēndices 1, 2, 3 e 4), o qüe indica que o desenvolvimento do inseto neste período é alongado por influência de baixas temperaturas (Tabela 12 e Figura 4).

Talvez, além da temperatura, o fotoperíodo nesta época do ano, possa afetar o desenvolvimento do inseto em condições de campo. A influência da interação temperatura-foto período foi relatada por OSMAN (1975) e PARRA et a $i$ i (1983), que verificaram que em insetos mantidos sob regime de fotope. riodo curto e temperaturas baixas ocorre um alongamento da fase larval da praga. Por outro lado, SGRILLO (1979), em modelo matemático proposto para D. saccharalis, considerou que as lagartas desta espēcie entram em diapausa em fotofases menores do que 11,6 horas, associadas a temperaturas abaixo de $210 \mathrm{C}$.

A estimativa do número de gerações de $D$. saccha ralis, baseado nas suas exigências térmicas, não pode ser con- 
siderado como definitivo, uma vez que a população da praga em condições naturais, não é regulada apenas pela temperatura, em bora este elemento climático seja um importante regulador (CHAR PENTIER et alii, 1967; FLOYD, 1966; GALLO, 1964; HENSLEY, 1971; HOLLOWAY e HALEY, 1927; WALDER, 1976). Além deste fator, outros podem afetar a flutuação nopulacional da broca em condições de campo, tais como parasitos-predadores (DEGASPARI et a $2 i$, 1981; DEGASPARI et alii, 1983a); outros fatores climáticos; tratos culturais (queima da cana) (DEGASPARI et alii, 1983b), etc.

Por outro lado, como no presente trabalho não foi determinada a temperatura base superior, é provável que existam períodos no ano nos quais o inseto terá dificuldades para seu normal desenvolvimento, uma vez que KING et alii (1975) observaram que $D$. saccharalis não se desenvolve em temperaturas acima de $34^{\circ} \mathrm{C}$. Desta forma, sugere-se que sejam conduzidos estudos neste sentido, pois pelos resultados obtidos esta temperatura base superior deve situar-se entre 32 e $35^{\circ} \mathrm{C}$. Raciocínio análogo pode ser feito com relação às temperaturas baixas que ocorrem durante os meses frios do ano, nas 4 localidades, que devem também afetar o normal desenvolvimento do inseto, ou mesmo serem letais, e que não foram consideradas no presente trabalho.

De acordo com estes resultados, embora baseados em dados macroclimáticos, pode-se afirmar que o modelo obtido em condições de laboratório pode ser aplicável em condições de campo, dentro do programa de controle integrado de D. sacchara 
lis, principalmente em modelos que visem a previsão de ocorrên cia da praga em condições naturais. Entretanto, são necessá rias pesquisas que visem estudar o efeito de outros elementos climáticos no desenvolvimento da praga, como a umidade, por exemplo; o efeito de caracteristicas hidricas e nutricionais da planta na evolução populacional da praga e principalmente estú dos de laboratório que permitam identificar se o inseto realmente apresenta "diapausa" em nossas condições. Estes estudos sobre "diapausa" devem ser conduzidos em laboratório, medindo-se parâmetros característicos de um inseto em diapausa, tais como diminuição do metabolismo, aumento de reservas gordurosas, diminuição do nível de enzimas oxidativas, diminuição do conteúdo de água no corpo, resistência às baixas temperaturas, etc. (PARRA, 1979), pois a caracterização de um inseto em diapausa pelo simples levantamento populacional, em condições de campo, pode levar a imperfeições, dada a dificuldade de amostragem dos estágios iniciais de desenvolvimento larval de $D$. saccharalis. 

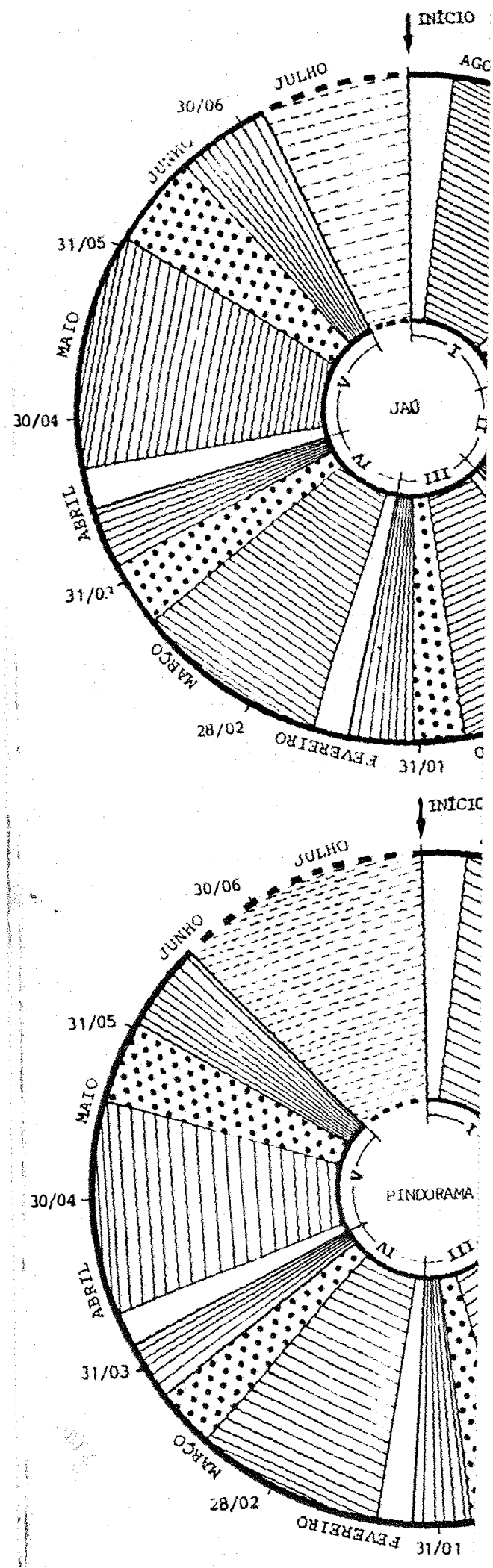

Eigura 7 - Número tante 


\section{CONCLUSÕES}

Com base nos resultados obtidos na presente pes quisa com Diatraea saccharalis (Fabricius, 1794), podem ser es tabelecidas as seguintes conclusões:

5.1. O período de incubação é decrescente com a elevação térmica.

5.2. A duração da fase larval é inversamente proporcional ao aumento da temperatura.

5.3. Com a elevação térmica, a duração da fase pupal, para ambos os sexos, é decrescente na faixa de 20 a $30^{\circ} \mathrm{C}$.

5.4. Há menor viabilidade, tanto para fase larval como pupal, à $32^{\circ} \mathrm{C}$. 
5.5. A temperatura afeta o nümero de instares.

5.6. O peso de pupas, de ambos os sexos é menor à $32^{\circ} \mathrm{C}$, sen do que em todas as condições as pupas que deram fêmeas foram mais pesadas.

5.7. Há uma maior porcentagem de adultos deformados à $32^{\circ} \mathrm{C}$.

5.8. A longevidade de adultos é decrescente com a elevação térmica, na faixa de 20 à $300^{\circ}$, sendo que em todas as condições as fêmeas viveram mais.

5.9. A temperatura não afeta o período de pré-oviposição.

5.10. O nümero de posturas diminui com o aumento da temperatura.

5.11. A temperatura de $20^{\circ} \mathrm{C}$ é a mais adequada para postura, havendo uma diminuição no número de ovos por fêmea com o aumento da temperatura.

5.12. A maior porcentagem de postura ocorre entre o primeiro e quarto dias.

5.13. O ciclo total do inseto é decrescente com a elevação tērmica. 
5.14. A viabilidade total do ciclo é maior à $300 \mathrm{C}$.

5.15. A taxa liquida de reprodução $\left(R_{0}\right)$ e a razão finita de aumento $(\lambda)$ são maiores à 20 e $30^{\circ} \mathrm{C}$, respectivamente.

5.16. A temperatura de $30{ }^{\circ} \mathrm{C}$ è a mais adequada para manutenção de ovos, lagartas e pupas.

5.17. As temperaturas bases são de 11,$2 ; 7,3 ; 10,6$ e $7,1^{\circ} \mathrm{C}$ para as fases de ovo, lagarta, pupa e adulto, respecti vamente.

5.18. As exigências térmicas das fases de ovo, lagarta, pupa e adulto são respectivamente 67,$47 ; 516,96 ; 126,08$ e $172,02 \mathrm{GD}$.

5.19. Nas localidades de Piracicaba, Ribeirão Preto, Jaú e Pindorama, o inseto pode apresentar cinco gerações anuais completas. 


\section{LITERATURA CITADA}

ALVAREZ, L., 1970. Contribución a la bionomia del borer de la caña de azúcar [Diatraea saccharalis (Fabr.] (Lepidoptera Crambidae). Havana, Universidad de La Habana, $34 \mathrm{p}$.

ARAÚJO, J.R.; S.M.S. ARAÚJO; P.S.M. BOTELHO; N. DEGASPARI, 1980. Obtenção de posturas de Diatraea saccharalis em condições de laboratório. Brasil Açucareiro. Rio de Janeiro,

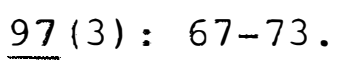

ARAÚJO, J.R.; S.M.S. ARAÚJO; P.S.M. BOTELHO; N. DEGASPARI, 1982. Biologia da Diatraea saccharalis em condições de campo. Brasil Açucareiro. Rio de Janeiro, 99(2): 31-34. 
ARNOLD, C.Y., 1959. The determination and significance of the base temperature in a linear heat unit system. Proceedings of the American Society for Horticultural Science. St. Joseph, 74: $430-445$.

BERGAMIN, J., 1943. Métodos de laboratório para observação e criação de Diatraea saccharalis (Fabricius, 1794), a broca da cana. Arquivos do Instituto Biológico. São Paulo, 14: $351-355$.

BERGAMIN, J., 1948. A broca daa cana-de-açúcar. Brasil Açucareiro. Rio de Janeiro, $\underline{32}(5): 72-76$.

BERGAMIN, J., 1949. A broca da cana-de-açúcar [Diatraea saccharalis (F.)]. Ligeiras notas sobre seu desenvolvimento em laboratório. In: LIMA, A.C. Insetos do Brasil. Ed. Nacional de Agronomia. Vol. 6, 2ạ parte, p.61-76.

BERTELS, A., 1970. Estudos da influência da umidade sobre a dinâmica de populações de lepidópteros, pragas do milho. Pesquisa Agropecuária Brasileira. Rio de Janeiro, 5: 67-79.

BOWLING, C.C., 1967. Rearing of two lepidopterous pests of rice on a common artificial diet. Annals of the Entomological Society of America. Columbus, 60 (6) : 1215-1216. 
BOX, H.E., 1925. Sugar-cane moth borers (Diatraea spp.) in British Guiana. Bulletin of Entomological Research. London, 16: $249-266$.

BOX, H.E., 1952. Informe preliminar sobre taladores de la caña do azúcar (Diatraea spp.) en Venezuela. Boletin Técnico do Instituto Nacional de Agricultura. Maracay, no 2, 91 p.

BREWER, F.D., 1976. Development of the sugarcane borer on various artificial diets. ARS, United State Department of Agriculture. Washington, 116: 1-6.

BREWER, F.D., 1977. Alternate protein sources and supplemental B-vitamin requeriments in rearing the sugarcane borer on a wheat germ diet. Journal Georgia Entomology Society. Athens, $\underline{12}(4): 283-291$.

BREWER, F.D., 1981. Development of Heliothis virescens and Diatraea saccharaits on a soyflour-corn oil diet. Annals of the Entomological Society of America. Columbus, 74 (3): 320-323.

BUTT, B.A. e E. CANTU, 1962. Sex determination of lepidopterous pupae. ARS, United States Department of Agriculture. Washington, n. $33-75,7 p$. 
CAMPOS, H. de, 1979. Estatistica Experimental Não-Paramétrica. 3ed. Piracicaba, ESALQ/USP, $343 \mathrm{p}$.

CHARPENTIER, J.J.; R. MATHES; W.J.MCCORMICK; J.W. SANFORD, 1967. Injury and losses caused by the sugarcane borer in Louisiana. In: Proceedings of 12 th Congress of International Society of Sugar Cane Technologists. Manila, p.1383-1387.

DEGASPARI, N.; N. MACEDC; J. BORGES; P.S.M. BOTELHO, 1981. Artrópodos predadores erı cana-de-açúcar. In: Congresso Nacional da STAB. Rio de Janeiro, p.13.

DEGASPARI, N.; P.S.M. BOTELHO; N. MACEDO, 1983a. A melhor opcão de controle da broca da cana-de-açúcar na região centro-sul. STAB. Rio de Janeiro, 1(4): 40-43.

DEGASPARI, N.; N. MACEDO; P.S.M. BOTELHO; L.C. ALMEIDA; J.R. ARAŪJO, 1983b. A queima da cana-de-açúcar, os efeitos sobre a população da broca Uiatraea saccharaìis (Fabr., 1794), seus predadores e parasitos. In: Resumos do 89 Congresso Brasileiro de Entomologia. Brasilia, p.207.

DYAR, H.G., 1890. The number of molts of lepidopterous larvae. Psyche. Massachusets, 5: 420-422. 
FERRAZ, M.C.V.D., 1982. Determinação das exigências térmicas de Spodoptera frugiperda (J.E. SMITH, 1797) (Lepidoptera, Noctuidae) em cultura de milho. Piracicaba, ESALQ/USP, 81p. [Dissertação de Mestrado].

FLOYD, E.H., 1966. Survival of the sugarcane borer owerwintering in corn stalks in Louisiana. Journal of Economic Entomology. Geneva, $59(4): 825-827$.

FUCHS, T.W. e J.A. HARDING, 1978. Oviposition patterns, egg parasitism, and spring emergence of the sugarcane borer Diatraea saccharalis. Environmental Entomology. College Park, $\underline{\underline{7}}(4): 601-604$.

FUCHS, T.W.; J.A. HARDING; J.W. SMITH, 1979. Induction and termination of diapause in the sugarcane borer. Annals of the Entomological Society of America. Columbus, $72(2): 271-$ -274 .

GALLO, D., 1964. Pragas da cana-de-açúcar. In: Cultura e adubação da cana-de-açúcar. São Paulo, Instituto Brasileiro da Potassa, p.192-198.

GALLO, D., 1980. Situação do controle biológico da broca da cana-de-açúcar no Brasil. Anais da Sociedade Entomológica do Brasil. Jaboticabal, $9(2): 303-308$. 
GALLO, D.; O. NAKANO; F.M. WIENDL; S. SILVEIRA NETO; R.P.L. CARVALHO, 1970. Manual de Entomologia. São Paulo, Ed. Agronômica Ceres, $854 \mathrm{p}$.

GALLO, D.; R.N. WILLIAMS; A.S. PEDROSO; E. BERTI FILHO, 1971. Curso sobre criação e alimentação artificial da broca da cana-de-açúcar (Diatraea saccharalis) para utilização na obtenção de inimigos naturais. Piracicaba, ESALQ/USP, 4p. [Mimeografado].

GALLO, D.; O. NAKANO; S. SILVEIRA NETO; R.P.L. CARVALHO; G.C. de BATISTA; E. BERTI FILHO; J.R.P. PARRA; R.A. ZUCCHI; S.B. ALVES, 1978. Manual de Entomologia Agrícola. São Paulo, Ed. Agronômica Ceres, 551p.

GRAU, P.A. e L.C. TERRIERE, 1967. A temperature-dependent factor for normal wing development in the cabbage looper, Trichoplusia $n i$ (Lepidoptera - Noctuidae). Annals of the Entomological Society of America. Columbus, 60 (3): 549-552.

GUEVARA, L.A.C., 1976. Aspectos da biologia em condições naturais e freqüência de acasalamento da Diatraea saccharalis (Fabr., 1794) (Lepidoptera - Crambidae) a broca da cana-de-açúcar. Piracicaba, ESALQ/USP, 70p. [Dissertação de Mestrado] 
HAYWARD, K.J., 1943. A broca da cana-de-açúcar. Brasil Açucareiro. Rio de Janeiro, 22(11): 69-74.

HENSLEY, S.D., 1969. Comparison of growth and development of sugarcane borer larvae from Puerto Rico and Louisiana. Journal of Agriculture of the University Puerto Rico. Rio Pedras, 1: 147-148.

HENSLEY, S.D., 1971. Management of sugarcane borer populations in Louisiana, a decade of change. Entomophaga. Paris, 16(1): $133-146$.

HENSLEY, S.D. A A.H. HAMMOND, 1968. Laboratory techniques for rearing the sugarcane borer on an artificial diet. Journal of Economic Entomology. Geneva, 61 (6): 1742-1743.

HOLLOWAY, T.E. e W.E. HALEY, 1927. Factors influencing the abundance of the sugar cane moth borer. Facts about Sugar. Russel Palmer, 22(2): 42-43.

HOLLOWAY, T.E.; W.E. HALEY; V.C. LOFTIN; C. HEIRINCH, 1928. The sugarcane moth borer in the United States. United States Department of Agriculture, Tech. Bulletin, 41, 31p.

INSTITUTO DE ECONOMIA AGRICOLA, 1982. Prognóstico 82/83. São Paulo, Secretaria da Agricultura, 11: 115-121. 
JASIC, J., 1967a. Aporte a la cuestion de la fecundidad de Diatraea saccharalis. Poeyana. Havana, no 38, 6p. Apud: Review of Applied of Entomology. Serie A. London, 56: 452. 1968 .

JASIC, J., 1967b. Influencia de las condiciones de temperatura en la evolución de Diatraea saccharalis (Fabricius). Poeyana. Havana, no 39, 9p. Apud: Review of Applied of Entomology. Serie A. London, 56: 452. 1968.

KASTEN, P.Jr., 1980. Biologia de Alabama argizlacea (Hübner, 1818) (Lepidoptera-Noctuidae) em diferentes temperaturas, na cultivar de algodoeiro "IAC-17". Piracicaba, ESALQ/USP, 56p. [Dissertação de Mestrado].

KATYAR, K.P. e W.H. LONG, 1961. Diapause in the sugarcane borer, Diatraea saccharalis. Journal of Economic Entomology. Geneva, 54 : 285-287.

KING, E.G.; F.D. BREWER; D.F. MART'IN, 1975. Development of Diatraea saccharalis (Lep.: Pyralidae) at constant temperatures. Entomophaga. Paris, 20(3): 301-306.

KIRST, L.D. E S.D. HENSLEY, 1974. A study of the overwintering populations of Diatraea saccharalis (F.) in Louisiana. In: Proceedings of 14 th Congress of International Society of Sugar-Cane Technologists. New Orleans, p.475-487. 
LARA, F.M., 1974. Influência de fatores ecológicos na coleta de algumas pragas com armadilhas luminosas. Piracicaba, ESALQ/USP, 142p. [Dissertação de Mestrado].

MACEDO, N.; A.C. MENDES; P.S.M. BOTELHO; O. NAKANO, 1976. Criação massal em laboratório de Diatraea saccharalis (F., 1794) sobre arroz (Oryza sativa). Brasil Açucareiro. Rio de Janeiro, $87(1): 65-67$.

MACEDO, N.; P.S.M. BOTELHO; N. DEGASPARI; L.C. ALMEIDA; J.R. ARAÚJO; E.A. MAGRINI, 1983. Controle biológico da broca da cana-de-açúcar. Piracicaba, IAA/PlAnAlsuCAR, 22p.

MANPRIM, M.C. e S.A. de BORTOLI, 1983. Aspectos ecológicos de Diatraea saccharalis (Fabr., 1794) (Lep.:Pyralidae) em milho. In: Resumos do 89 Congresso Brasileiro de Entomologia. Brasilia, p.1.

MEADOWS, C.M., 1938. 'The biolory of the sugarcane borer Diatraea saccharalis (F.). Baton Rouge, LSU, 50p. \{Master of Science Thesis] . 
MENDES, A.C., 1976. Influência dos elementos climáticos sobre a população da broca da cana-de-açúcar, Diatraea saccharalis (Fabr.) e da cigarrinha da raiz Mahanarva fimbriolata (Stal). Araras, São Paulo. Piracicaba, ESALQ/USP, 104p. [Dissertação de Mestrado] .

MENDES, A.C., 1980. Métodos de criação de parasitos da broca da cana-de-açúcar Diatraea saccharalis (Fabricius, 1794). In: Anais do 69 Congresso Brasileiro de Entomologia. Campinas, p.103-132.

MENDES, A.C.; P.S.M. BOTELHO; N. MACEDO, 1977. Estudos comparativos de novos substratos para oviposição de Diatraea saccharalis (Fabr., 1794) (Lep.:Crambidae) em condições de laboratório. Brasil Açucareiro. Rio de Janeiro, 87 (6): 73-77.

MENDONÇA FILHO, A., 1973. Criação artificial em laboratório dos parasitos da broca da cana-de-açúcar (Diatraea spp.) (Lep., Crambidae). Brasil Açucareiro. Rio de Janeiro, 81(4): 47-80.

MENDONÇA FILHO, A., 1978. As brocas da cana-de-açúcar Diatraea saccharalis (Fabricius, 1794) e Diatraea flavipennella (BOX, 1931) (Lepidoptera:Pyralidae) e seu controle biológico no Estado de Alagoas. Piracicaba, ESALQ/USP, 201p. [Dissertação de Mestrado] .

MISKIMEN, G.W., 1965. Nonaseptic laboratory rearing of the sugarcane borer, Diatraea saccharalis. Annals of the Entomological Society of America. Columbus, 58 (6): 820-823. 
MISKIMEN, G.W., 1973. High-temperature effects on sugarcane borers. 2. Mating success, fecundity, and fertility. Environmental Entomology. College Park, $\underline{2}(6):$ 986-990.

NOVARETTI, W.R. e F.O. TERAN, 1976. Melhorias introduzidas nas dietas usadas para criação da Diatraea saccharalis (Fabr., 1794). In: Anais do IV Seminário COPERSUCAR da Agroindústria Açucareira. São Paulo, p.81-84.

OSMAN, N.B., 1975. Response of sugarcane borer larvae, Diatraea saccharalis (F.) to photoperiod and temperature. Baton Rouge, State University, 84p. [Master of Science Thesis].

OSORES, V.M.; E. WILLINK; M.A. COSTILLA, 1982a. Generaciones de Diatraea saccharalis y daño producido en cañaverales de la Provincia de Tucumán. Revista Industrial y Agricola de Tucumán. San Miguel de Tucumán, 58(2): 49-56.

OSORES, V.M.; E. WILLINK; M.A. COSTILLA, 1982b. Cria de Diarraea saccharalis F. en laboratório. Estaciōn Experimental Agro-Industrial "O BISPO COLOMBRES", San Miguel de Tucumán, 10p. [Boletin no 39].

PAN, Y. e W.H. LONG, 1961. Diets for rearing the sugarcane borer. Journal of Economic Entomology. Geneva, $54(2): 257-261$ 
PARRA, J.R.P., 1979. Biologia dos insetos. Piracicaba, ESALQ, 383p. [Mimeografado] .

PARRA, J.R.P., 1981. Biologia comparada de Perileucoptera coffeella (Guérin-Mèneville, 1842) (Lepidoptera:Lyonetiidae), visando ao seu zoneamento ecológico no Estado de são Paulo. Piracicaba, ESALQ/USP, 96p. [Tese de Livre-Docência].

PARRA, J.R.P.; A.B.P. MÉLO; B.P. MAGALHÃES; S. SILVEIRA NETO; P.S.M. BOTELHO, 1983. Efeito do fotoperíodo no ciclo biológico de Diatraea saccharalis. Pesquisa Agropecuária Brasileira. Brasilia, 18(5): 463-472.

PETERS, T.M. e P. BARBOSA, 1977. Influence population density on size, fecundity, and development rate of insects in culture. Annual Review of Entomology. Palo Alto, 22: 431-450 .

PICKEL, B., 1939. Os insetos daninhos da cana-de-açúcar em Pernambuco. Brasil Açucareiro. Rio de Janeiro, 12 (5) : 39-45 .

PLANALSUCAR, 1976-1982. Relatório Anual da Seção de Entomologia Coordenadoria Regional Sul. Araras, SP. 
PRUNA, P.M., 1969. Revision de la literatura acerca del borer de la caña de azúcar, Diatraea saccharalis (Fabricius). Academia de Ciências. Havana, Série Biológica, no 5, 66p.

RATKOVICH, M., 1953. El gusano perforador de la caña de azúcar. Revista Agronômica del Noroeste Argentino. San Miguel de Tucumān, 11(1): 1-67.

RISCO, S.H., 1959. Combating the borer in Peru success of the campaing of biological control. In: Proceedings of 11 th Congress of International Society of Sugar Cane Technologists. Hawai, p.877-886.

RISCO, S.H.; N. MORALES; G. AYQUIPA, 1973. Uma dieta para la crianza masiva de orugas del borer de la caña de azúcar: Diatraea saccharalis (Fabr.) (Lep.:Crambidae). Saccharum. São Paulo, 1 (1): 27-4z.

ROE, R.M.; A.M. HAMMOND; T.C. SPARKS, 1982. Growth of larval Diatraea saccharalis (Lepidoptera:Pyralidae) on an artificial diet and synchronization of the last larval stadium. Annals of the Entomological Society of America. Columbus, 75(4): 421-429 . 
SANTA CRUZ, J.M.S.; C.S. MOSS; G.G. RAYNAUD; C.G. MONTALVO, 1964. Cria artificial de Diatraea saccharalis Fab. (Lepidoptera:Pyralidae) y su aplicación en la evolución de resistencia en maiz. Agrociencia. Mexico, 18: 3-13.

SCHAFER, J.; P. GRAU; L.C. TERRIERE, 1968. Temperature-induced wing malformation in alfalfa loopers and variegated cutworms. Journal of Economic Entomology. Geneva, 61(2): 575-576.

SGRILLO, R.B., 1973. Criação em laboratório da broca da cana-de-açúcar [Diatraea saccharalis (Fabricius, 1794)] visando seu controle. Piracicaba, ESALQ/USP, 98p. [Dissertação de Mestrado] .

SGRILLO, R.B., 1979. Desenvolvimento de modelo matemático para população da broca da cana-de-açúcar Diatraea saccharalis (Fabr., 1794) e simulação da técnica do indivíduo estéril. Piracicaba, ESALQ/USP, 189p. [Tese de Doutoramento] .

SILVEIRA NETO, S., 1972. Levantamento de insetos e flutuação da população de pragas da Ordem Lepidoptera, com o uso de armadilhas luminosas, em diversas regiões do Estado de são Paulo. Piracicaba, ESAI Q/USP, 183p. [Tese de Livre-Docênciá]. 
SILVEIRA NETO, S.; O. NAKANO; D. BARBIN; N.A. VILLA NOVA, 1976. Manual de Ecologia dos Insetos. São Paulo, Ed. Ceres, 419p. STUBBS, W.C. e H.A. MORGAN, 1902. Cane borer (Diatraea saccharalis). Louisiana, Agriculture Expt. Sta. Bulletin, 70 : $888-927$.

TAYLOR, D.J., 1944. Life history studies of the sugarcane moth borer. Florida Entomologist. Gainesville, 27(1): 10-13.

TERAN, F.O., 1980. Criação de narasitos de Diatraea saccharalis (Fabricius, 1794). In: Anais do 69 Congresso Brasileiro de Entomologia. Campinas, p.133-140.

VAN DINTHER, J.B.M. e P.A. GOOSSENS, 1970. Rearing of Diatraea saccharalis on diets in Surinam. Entomologia Experimentalis et Applicata. Amsterdam, 13: 320-326.

VILLACORTA, A. e J.A. MAGRO, 1975. Criação massal de Diatraea saccharalis (Lepidoptera:Pyralidae) em laboratório. Anais da Sociedade Entomológica do Brasil. Jaboticabal, 4 $(1): 43-48$. 
WALDER, J.M.M., 1976. Estudo da população da Diatraea saccharalis (Fabr., 1794) em quatro regiões canavieiras do Estado de São Paulo. Piracicaba, ESALQ/USP, 111p. [Tese de Doutoramento] .

WALKER, D.W., 1968. Potential for control of sugarcane borer through radio-induced sterility. In: Radiation, radioisotopes and rearing methods in control of insects pests. Proceedings of a Painel. Tel-Aviv, IAEA, ‥131-140.

WALKER, D.W. e M. FIGUEROA, 1964. Biology of the sugarcane borer, Diatraea saccharalis (F.). III. Oviposition rate. Annals of the Entomological Society of America. Columbus, $\underline{57}(4): 515-516$.

WALKER; D.W.; A.V. ALFMAÑY; V. QUINTANA; F. PADOVANI; K.S. HAGEN, 1966. Improved xenic diets for rearing the sugarcane borer in Puerto Rico. Journal of Economic Entomology. Geneva, $\underline{59}(1): 1-4$.

WoLCOTT, G.N., 1915. The influence of rainfall and the nonburning of trash on the abundance of Diatraea saccharalis. Journal of Economic Entomology. Geneva, 8(5): 496-498. 
WONGSIRI, T. E N.M. RANDOLPH, 1962. A comparison of the biology of the sugarcane borer on artificial and natural diets. Journal of Economic Entomology. Geneva, 55(4): $472-473$. 
.97.

7. APÊNDICE 


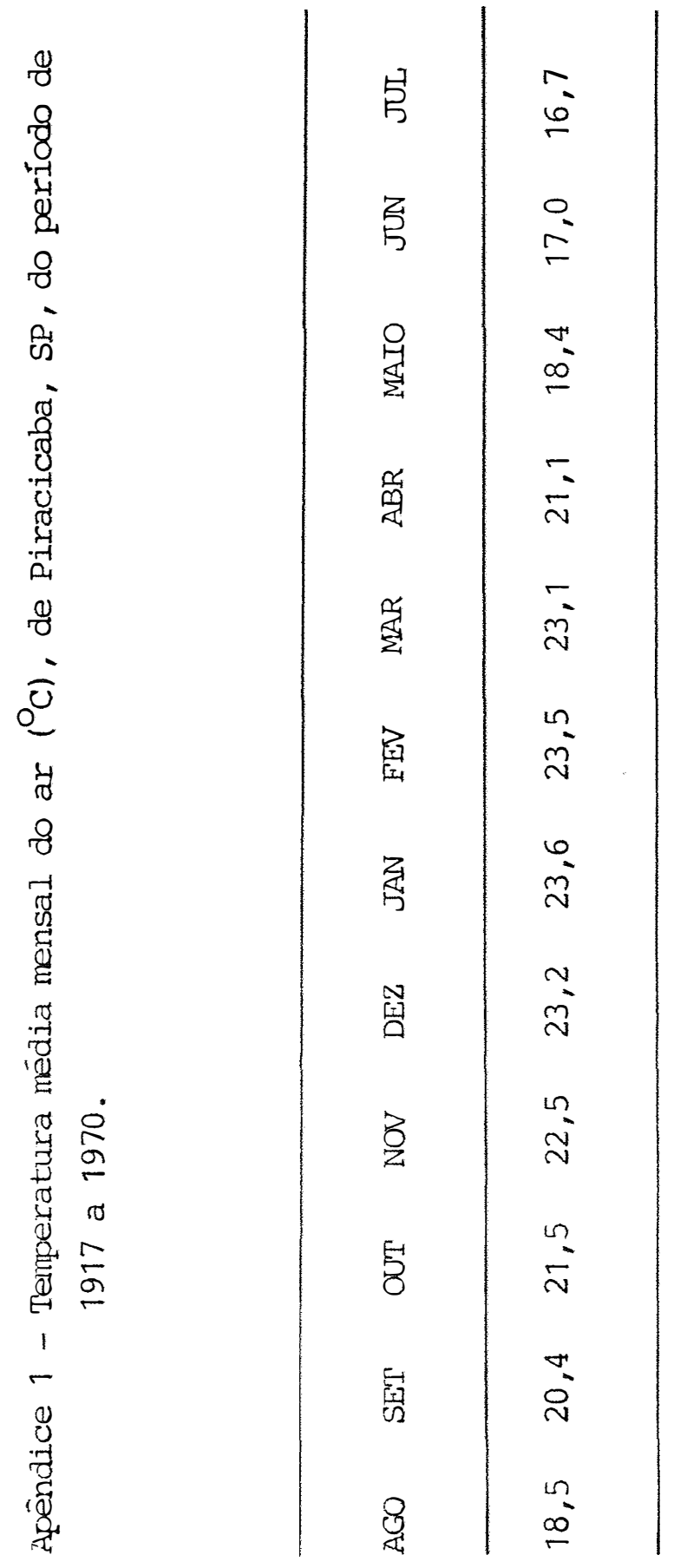




\begin{tabular}{|c|c|c|}
\hline$\stackrel{\infty}{\sim}$ & 趙 & 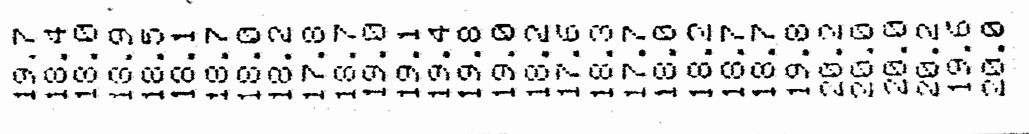 \\
\hline $\int_{0}^{1}$ & $\frac{g}{\xi}$ & 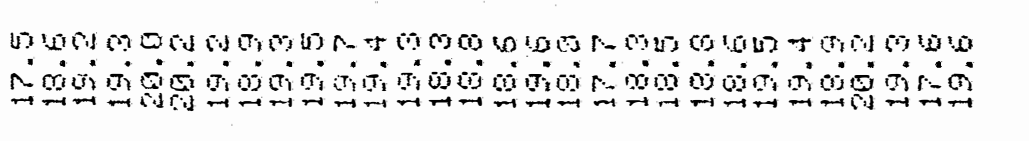 \\
\hline $\begin{array}{l}8 \\
8 \\
8\end{array}$ & 告 & 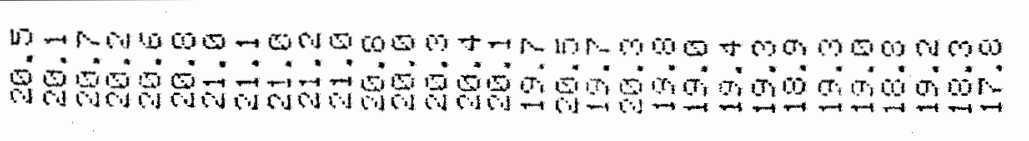 \\
\hline 8 & $\begin{array}{l}\overrightarrow{1} \\
\text { 妾 }\end{array}$ & 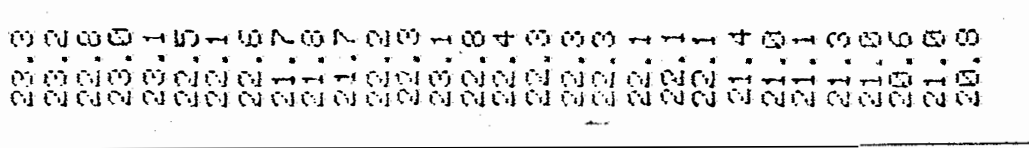 \\
\hline वें & 量 & 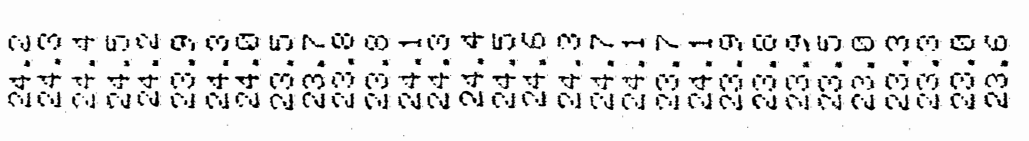 \\
\hline 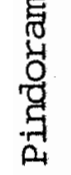 & 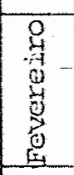 & Q \\
\hline$\frac{\ddot{U}}{\ddot{\theta}}$ & 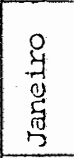 & 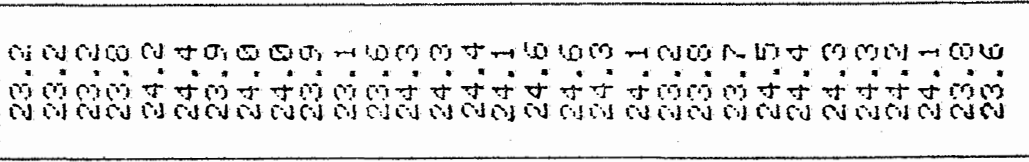 \\
\hline $\begin{array}{l}y \\
\text { y }\end{array}$ & 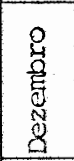 & 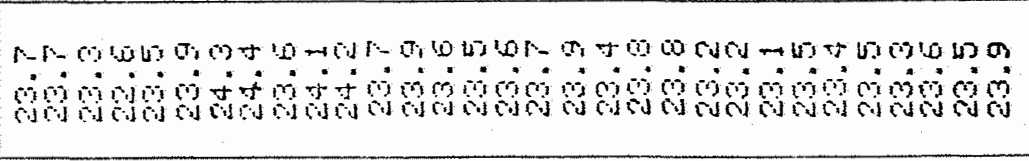 \\
\hline 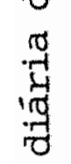 & 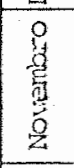 & कर \\
\hline 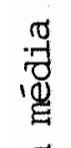 & 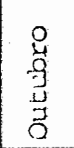 & 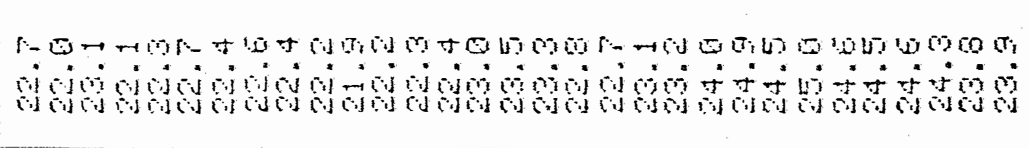 \\
\hline 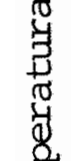 & 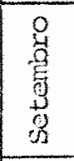 & कon \\
\hline 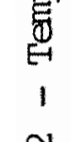 & 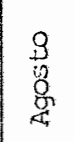 & 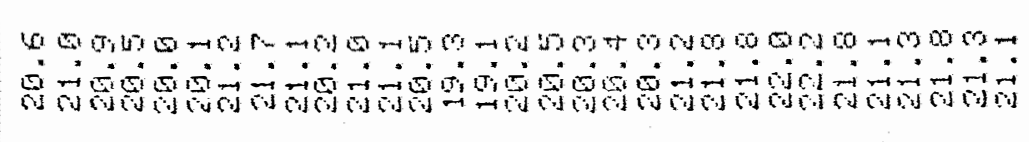 \\
\hline 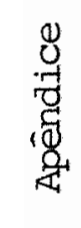 & 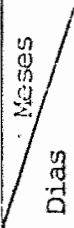 & 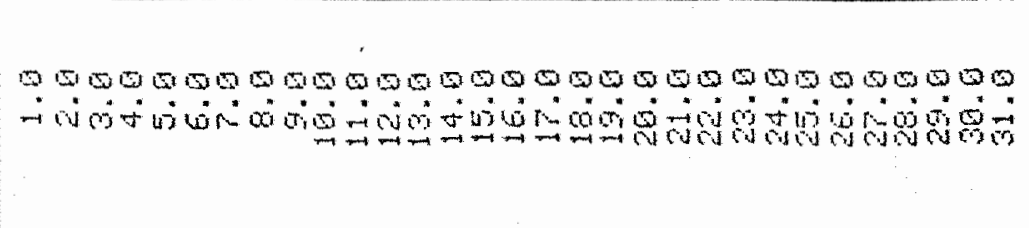 \\
\hline
\end{tabular}




\begin{tabular}{|c|c|c|}
\hline 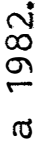 & $\begin{array}{l}\text { 号 } \\
\text { 官 }\end{array}$ & 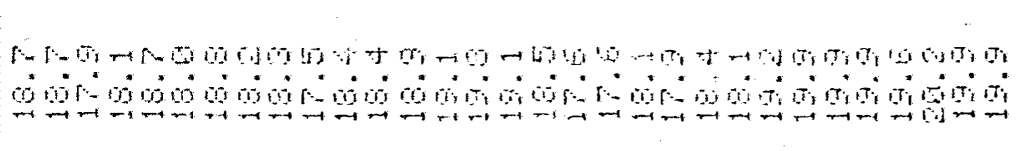 \\
\hline 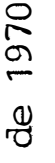 & $\frac{a}{3}$ & 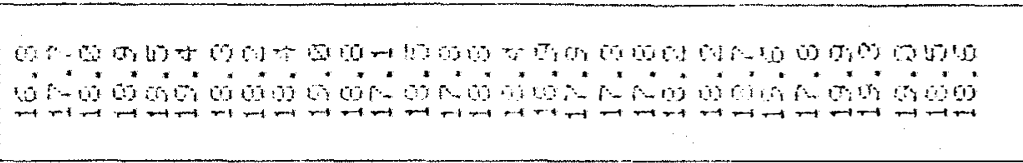 \\
\hline 要 & 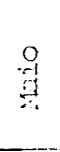 & a d a \\
\hline ì & 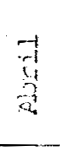 & a \\
\hline 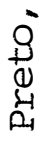 & 焉 & का \\
\hline 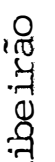 & 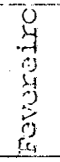 & की \\
\hline 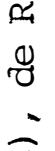 & $\begin{array}{l}0 \\
y \\
0 \\
0 \\
y \\
y\end{array}$ & क \\
\hline ¿ & $\begin{array}{r}0 \\
b \\
b\end{array}$ & mot \\
\hline 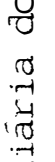 & $\begin{array}{l}9 \\
4 \\
3 \\
3\end{array}$ & 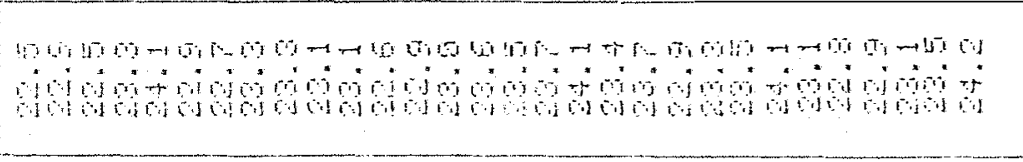 \\
\hline 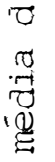 & $\begin{array}{c}3 \\
3 \\
3 \\
3 \\
3\end{array}$ & क की \\
\hline $\begin{array}{l}0 \\
0 \\
3 \\
0 \\
0 \\
0 \\
0 \\
0\end{array}$ & $\begin{array}{l}? \\
8 \\
3\end{array}$ & कor \\
\hline 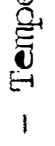 & $\begin{array}{l}3 \\
3 \\
3 \\
3\end{array}$ & का को \\
\hline 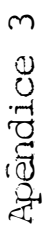 & $\begin{array}{l}8 \\
8 \\
0 \\
0 \\
0\end{array}$ & 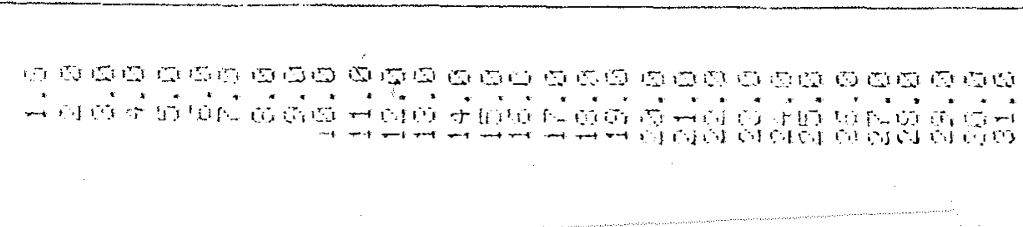 \\
\hline
\end{tabular}




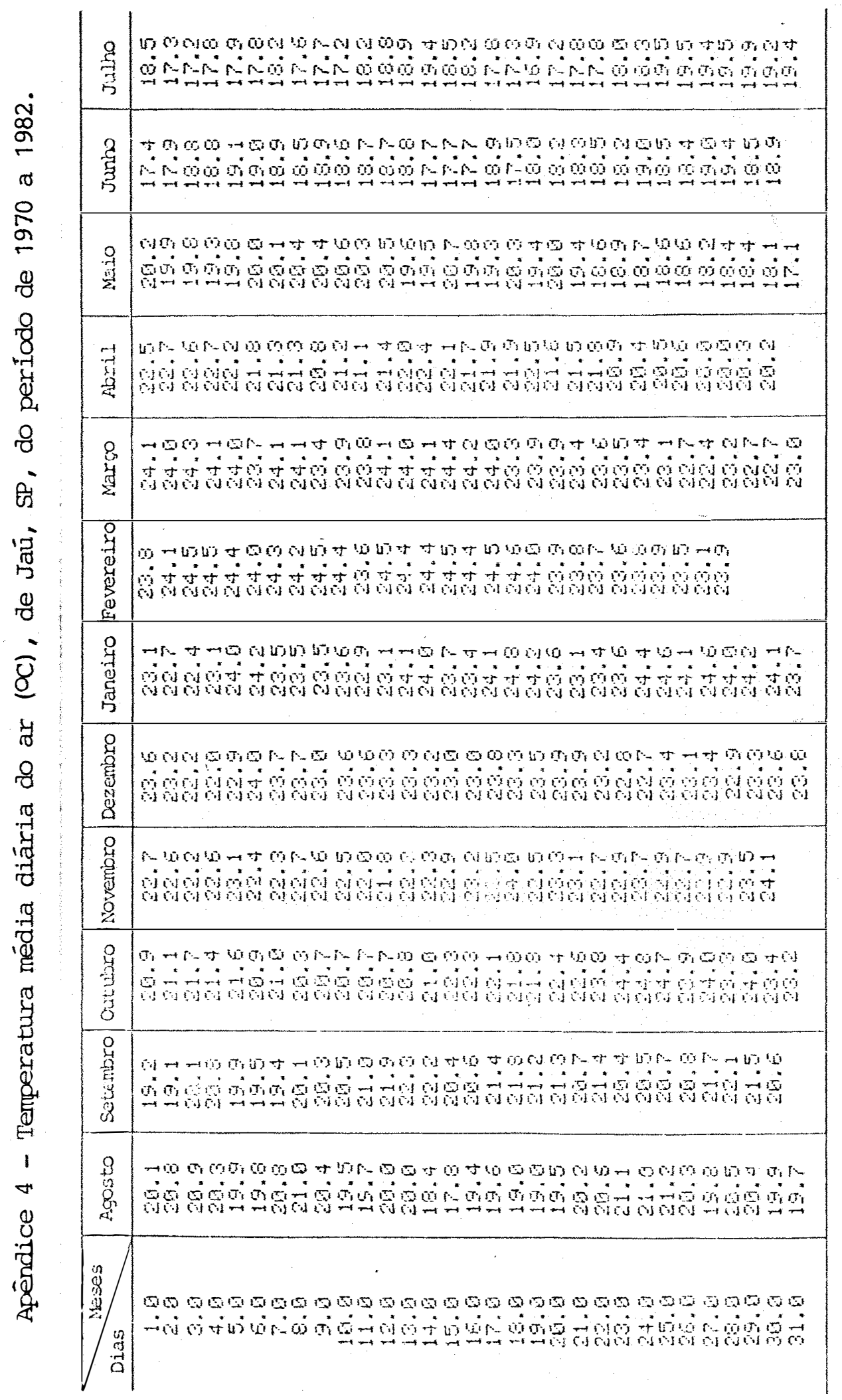

